INTER NATIONAL MONETARY FUND

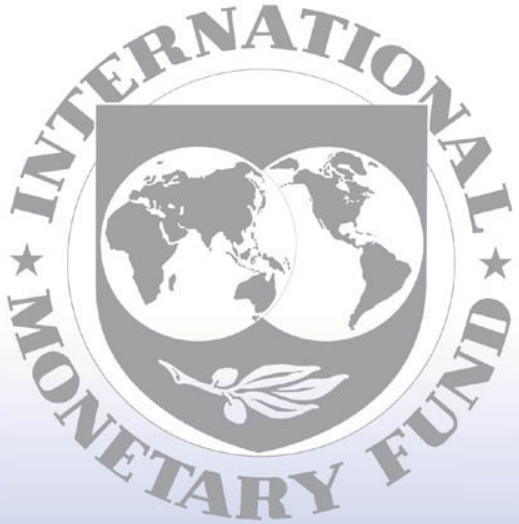

Staff






\section{Greece: Selected Issues}

This Selected Issues paper for Greece was prepared by a staff team of the International Monetary Fund as background documentation for the periodic consultation with the member country. It is based on the information available at the time it was completed on December 18, 2006. The views expressed in this document are those of the staff team and do not necessarily reflect the views of the government of Greece or the Executive Board of the IMF.

The policy of publication of staff reports and other documents by the IMF allows for the deletion of market-sensitive information.

To assist the IMF in evaluating the publication policy, reader comments are invited and may be sent by e-mail to publicationpolicy@imf.org.

Copies of this report are available to the public from

International Monetary Fund $\bullet$ Publication Services

700 19th Street, N.W. • Washington, D.C. 20431

Telephone: (202) 6237430 • Telefax: (202) 6237201

E-mail: publications@imf.org • Internet: http://www.imf.org

Price: $\$ 18.00$ a copy

\section{International Monetary Fund Washington, D.C.}




\section{INTERNATIONAL MONETARY FUND}

\section{GREECE}

\section{Selected Issues}

Prepared by Anastassios Gagales, Marco Rossi, and Marialuz Moreno Badia (all EUR)

Approved by European Department

December 19, 2006

This Selected Issues Paper examines three areas of key policy importance in the coming years. The first chapter documents the loss of international competitiveness in recent years, as well as the accompanying widening of the current account deficit. It concludes that clawing back lost competitiveness will take a combination of sound policies, wage restraint, and strong productivity growth. The second chapter analyzes fiscal consolidation episodes in advanced economies, and confirms the conclusion found in the literature that, for durable consolidation, control of current spending is superior to revenue increases. This result is applied to the 2005-06 fiscal consolidation in Greece, which relied mainly on spending restraint (although significantly on a fall in investment spending with the end of the Olympics), and, especially in 2006, on revenue increases. The third chapter estimates European banks' vulnerability to rapid credit growth and economic slowdowns, and finds that Greek banks appear to be more vulnerable than those in the rest of Europe. 
I. Greece's Competitiveness Deficit: How big is it and how could it be unwound? …............ $\underline{4}$

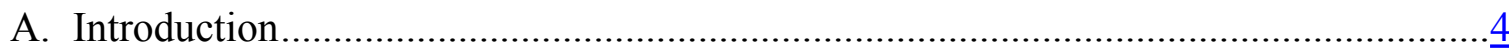

B. Indicators of External Performance ................................................................

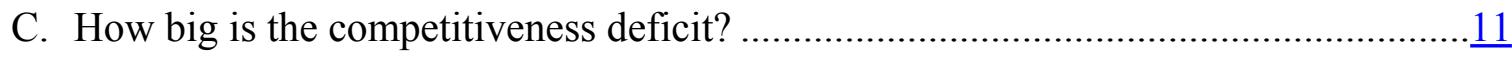

D. Constant Market Shares Analysis of Competitiveness ..........................................17

E. Should external imbalances be of concern in an EMU member country?..................20

F. How Could the lost competitiveness be clawed back? ...........................................24

Figures

1. External Current Account and its Determinants .......................................................... 8

2. Demand Stimuli, 1991-2006 ............................................................................

Box

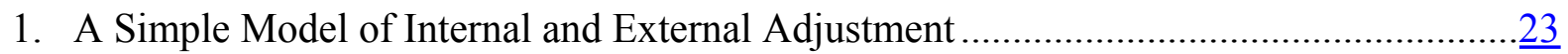

Annex

I. Derivation do the CMS Decomposition................................................................

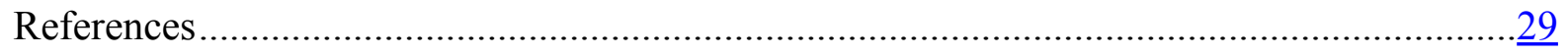

II. Greece's Fiscal Adjustment in an International Context .............................................31

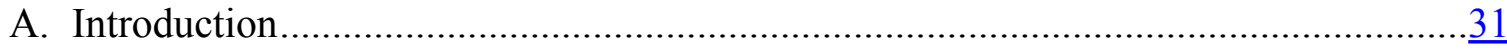

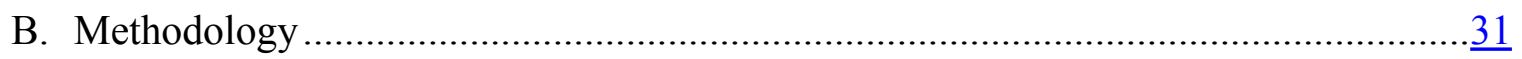

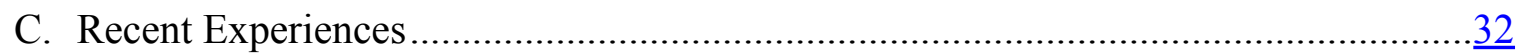

D. Fiscal Consolidation in Greece ............................................................................

E. Conclusions.......................................................................................

Figures

1. Expenditure Components, 1990-2004 ..........................................................................

2. Expenditure Components, 1990-2004 .....................................................................

3. Interest Payments, 1990-2004 ..............................................................................

4. Expenditure by Function, 1990-2004 .................................................................... 40

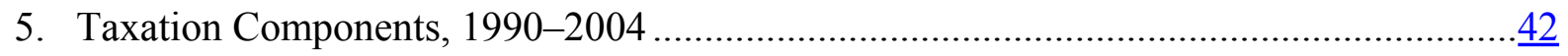

6. Taxation Components, 1990-2004 …....................................................................

7. Components of Fiscal Adjustment, 2004-06 ........................................................ 46

Tables

1. Fiscal Adjustment, Total Expenditure and Revenues .............................................

2. Fiscal Adjustment: List of Countries .................................................................

3. Fiscal Adjustment: Successes and Failures ............................................................ 


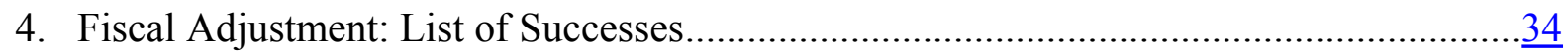

5. Characteristics of Successful and Failed Fiscal Adjustments...........................................

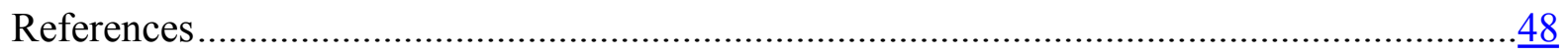

III. Credit Growth and Bank Vulnerability in the Euro Area and Greece ............................... 49

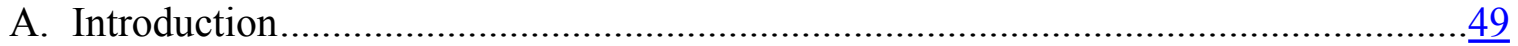

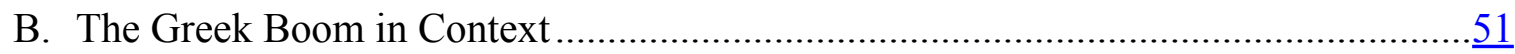

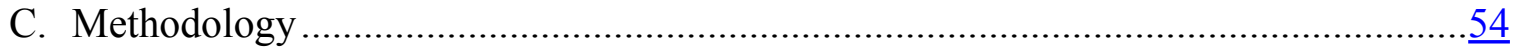

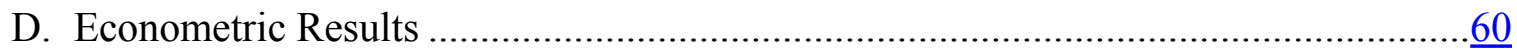

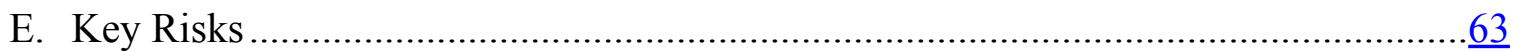

Figures

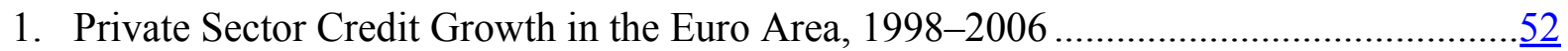

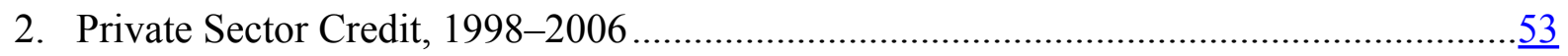

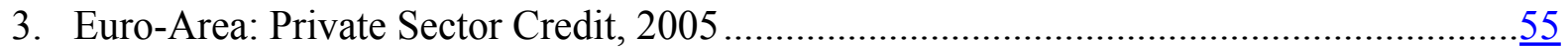

4. Greece and the Euro Area: Mean Values by Year........................................................

5. Histograms for Distance to Default and Bank Credit Growth, 1994-2005 …………........59

6. Correlation between Distance to Default and Bank Credit, 1994-2005 …………….........59

7. Greek Banks: Funding Structure.................................................................................63

Tables

1. Number of Banks in the Sample by Country and Year ………......................................67

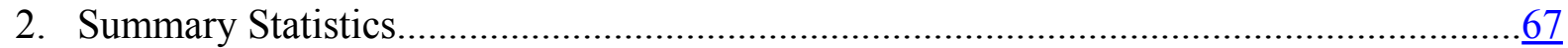

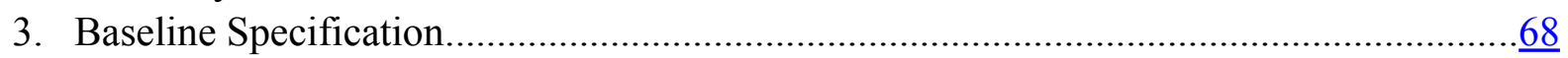

4. Baseline Specification Including Real House Price Inflation...........................................

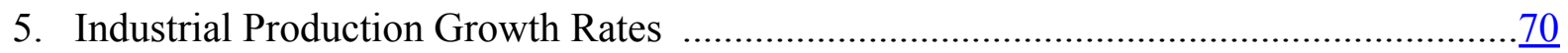

6. European Stock Market Indices ...........................................................................

7. Asymmetric Effects over Real Sector Downturns …….............................................

8. Asymmetric Effects over Equity Price Cycles..........................................................

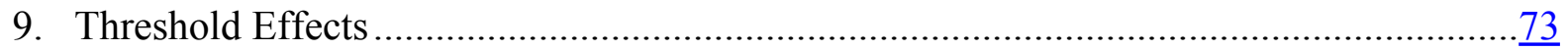

10. Core Set of Financial Soundness Indicators for Deposit-Taking Institutions .................... 74

Annex

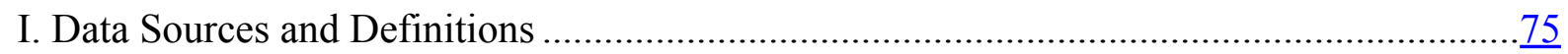

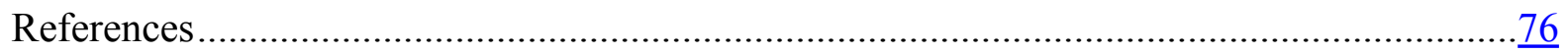




\section{GREECE'S COMPETITIVENESS DEFICIT: HOW BIG IS IT AND HOW COULD IT BE UNWOUND? ${ }^{1}$}

\section{A. Introduction}

\section{The Greek economy has been experiencing a renaissance, but lately external} imbalances have been mounting. Output and employment have grown robustly and respectable productivity gains have started to narrow the income differential vis-à-vis the euro area. ${ }^{2}$ However, growth has been driven mainly by domestic demand stimuli (financial system liberalization, lower interest rates following EMU accession, procyclical fiscal relaxation, and EU transfers), inflation has consistently exceeded the euro area average leading to a loss of competitiveness, and the external current deficit has widened to an unsustainable level. Looking forward, the stimuli that have propelled the economy are running their course.

2. This state of affairs raises a number of important policy questions. To what extent is the erosion of competitiveness a benign phenomenon? Should the widening of the external current account deficit be of concern for an EMU member country? Could export growth pick up the slack when the demand stimuli have run their course or would they be inhibited by overvaluation? What policies could engineer a soft landing?

\section{The main conclusions of this chapter are:}

- $\quad$ The external performance of the Greek economy has been weak on a number of dimensions. By all measures, the real exchange rate has become overvalued by some 17 percent (but with quite wide margins of error) since euro adoption due to high inflation and wage growth; non-price competitiveness compares poorly with other EU countries; export growth has been weak; and the current account deficit has expanded to an unsustainable level.

- $\quad$ To a large extent, the real appreciation and the widening current account deficit are driven by two shocks, the interest rate drop and financial liberalization. As these shocks fade, pressures on the exchange rate and the current account should ease.

- While the current account deficit itself may not reflect underlying economic distortions, and while Greece does not face a binding external financing constraint,

\footnotetext{
${ }^{1}$ Prepared by Anastassios Gagales (EUR).

${ }^{2}$ Unless otherwise stated, all figures are based on the national accounts prior to the September 2006 revision owing to the lack of sufficiently long GDP series (the new estimates, which are still provisional, are available only since 2000). The revision raised GDP by about 26 percent and reduced correspondingly all ratios to GDP. Although underlying economic conditions are unaffected by the revision, external imbalances appear less acute than previously.
} 
external adjustment will have to occur over the medium term. Reversing the competitiveness deficit will take a combination of wage restraint, productivity improvements, export growth, and domestic demand moderation. Prudent fiscal policies, bold structural reforms, and strong forward looking prudential oversight can help foster a soft landing.

4. The chapter is organized as follows: the next section looks at indicators of external performance, Section $\mathrm{C}$ estimates the underlying overvaluation of the real effective exchange rate, Section D analyzes export market performance, Section $\mathrm{E}$ examines the relevance of current account deficits and exchange rate overvaluation for EMU member countries, and Section F concludes with policy implications.

\section{B. Indicators of External Performance}

\section{All measures of the real effective exchange rate have appreciated significantly} since EMU accession, reaching historically high levels. ULC-based measures have appreciated by 20-30 percent and CPI-based measures by about 10 percent, reaching their highest level in a quarter century. The appreciation reflects rapidly rising unit labor costs (their annual growth has exceeded the euro-area average by 2.2 percentage points), relatively high inflation (on average, 1.2 percentage points above the euro area average), and the strengthening

\begin{tabular}{|c|c|c|c|c|c|c|c|c|}
\hline \multirow[b]{3}{*}{ Greece } & 2000 & 2001 & 2002 & 2003 & 2004 & 2005 & 2006 & Average \\
\hline & \multicolumn{8}{|c|}{ (Annual changes in percent) } \\
\hline & & & & & & & & \\
\hline Unit labor cost & 5.1 & 0.3 & 2.8 & 1.2 & 2.3 & 2.4 & 2.4 & 2.4 \\
\hline Labor productivity & 1.6 & 1.3 & 1.5 & 1.0 & 1.7 & 2.5 & 3.2 & 1.8 \\
\hline \multicolumn{9}{|l|}{ Portugal } \\
\hline Unit labor cost & 3.9 & 4.2 & 4.2 & 1.1 & 2.4 & 2.3 & 1.6 & 2.8 \\
\hline Labor productivity & 2.9 & 1.4 & 0.5 & -0.5 & 0.8 & 0.3 & 0.8 & 0.9 \\
\hline \multicolumn{9}{|l|}{ Spain } \\
\hline Unit labor cost & 2.3 & 4.1 & 2.9 & 0.9 & 0.5 & 2.5 & 1.9 & 2.2 \\
\hline Labor productivity & 0.5 & 0.0 & 2.0 & 4.1 & 3.4 & 1.0 & 1.1 & 1.7 \\
\hline \multicolumn{9}{|l|}{ Euro area } \\
\hline Unit labor cost & -1.1 & 1.9 & 1.9 & 0.4 & -1.0 & 0.0 & 0.3 & 0.3 \\
\hline Labor productivity & 4.3 & 1.3 & 1.5 & 2.7 & 3.7 & 2.5 & 2.6 & 2.6 \\
\hline
\end{tabular}
of the euro. Export prices (as measured by the export deflator) have been among the fastest growing in the euro area, indicating eroding competitiveness vis-à-vis other euro area partners ${ }^{3}$ their growth having fallen short of ULC growth points to a possible compression of profit margins in the export sector. These are clear indications that Greece has not yet fully adjusted to the currency union setting.

\footnotetext{
${ }^{3}$ Cross country differences in export deflators need to be interpreted with caution because, in addition to price effects, they reflect changes in the commodity composition and quality of exports, and the degree of market power. These are welfare improving and do not imply competitiveness loss.
} 

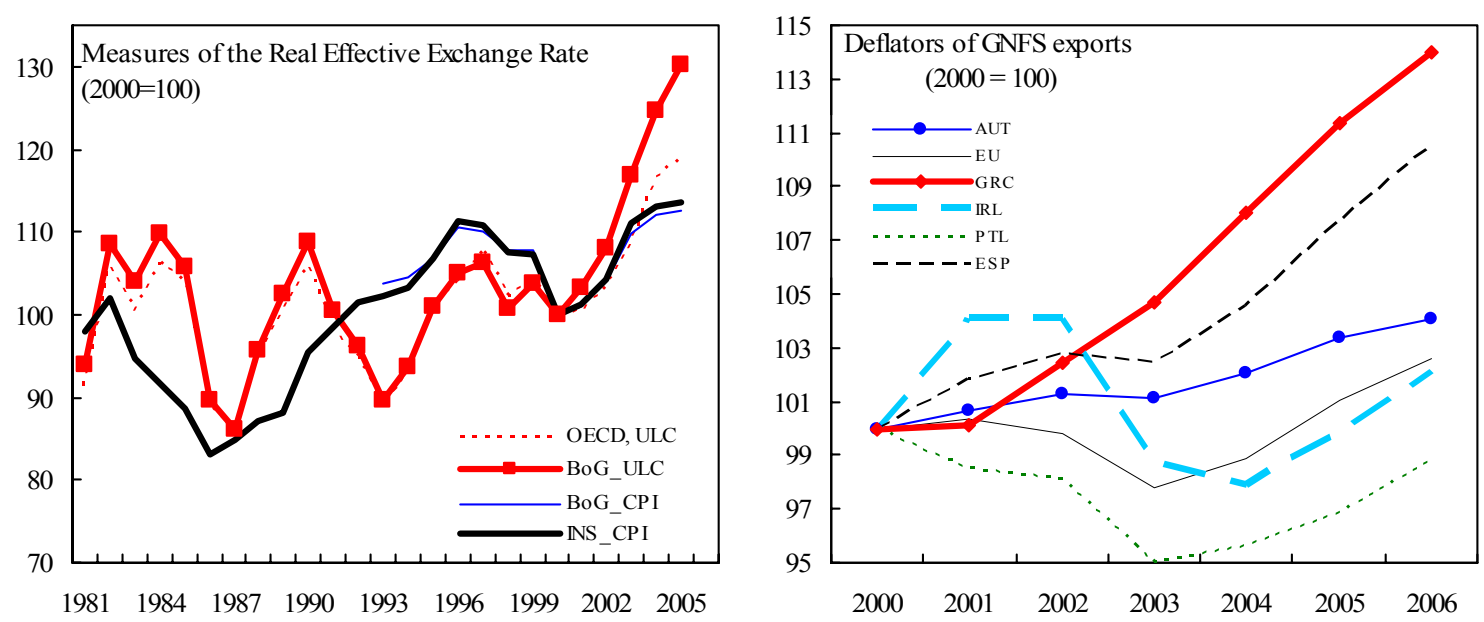

6. Eroding price/cost competitiveness has been accompanied by weak non-price competitiveness. Broad-based indicators — such as the international competitiveness rankings of the World Economic Forum (WEF) and the International Institute for Management Development (IMD) — which take into account the business environment, infrastructure, the quality of government and other factors that ultimately influence production costs, rank Greece low among EU countries. ${ }^{4}$ Poor non-price competitiveness is reportedly the main reason for chronically weak inward FDI.

Greece gets low scores in competitiveness rankings

\begin{tabular}{lccrr}
\hline & Portugal & Spain & Italy & Greece \\
\cline { 2 - 5 } & \multicolumn{4}{c}{ (Country ranking) } \\
Global Competitiveness Index, 2006, WEF & 34 & 28 & 42 & 47 \\
$\quad$ Institutions & 28 & 39 & 71 & 41 \\
& & & & \\
Competitiveness index (2006), IMD & 43 & 36 & 56 & 42 \\
$\quad$ Government efficiency & 42 & 40 & 60 & 46 \\
Index of Economic Freedom (2006), Heritage Foundation & 30 & 33 & 42 & 57 \\
Inward FDI performance index (2003-05), UNCTAD & 69 & 76 & 107 & 121 \\
\hline
\end{tabular}

Inward FDI as a percent of gross fixed capital formation (Average 2003-05)

\begin{tabular}{lr} 
Belgium & 50.6 \\
Ireland & 44.0 \\
United Kingdom & 22.3 \\
Netherlands & 19.2 \\
Sweden & 18.3 \\
Lithuania & 12.7 \\
Portugal & 12.6 \\
France & 12.0 \\
Finland & 11.2 \\
Austria & 11.0 \\
Spain & 8.8 \\
Italy & 5.6 \\
Germany & 3.4 \\
Greece & 2.7 \\
\hline
\end{tabular}

Source: Eurostat

\footnotetext{
${ }^{4}$ See also the 2006 Report of the Greek National Council for Competitiveness and Development.
} 
7. The erosion of competitiveness is reflected in export performance. Export volume growth has been the second lowest among euro area countries in the period since EMU accession, notwithstanding the very fast growth in Greece's export markets. Correspondingly, exporters have been losing market share, notably in the rapidly expanding neighboring Balkan countries.

Export growth has been the second slowest among euro area countries

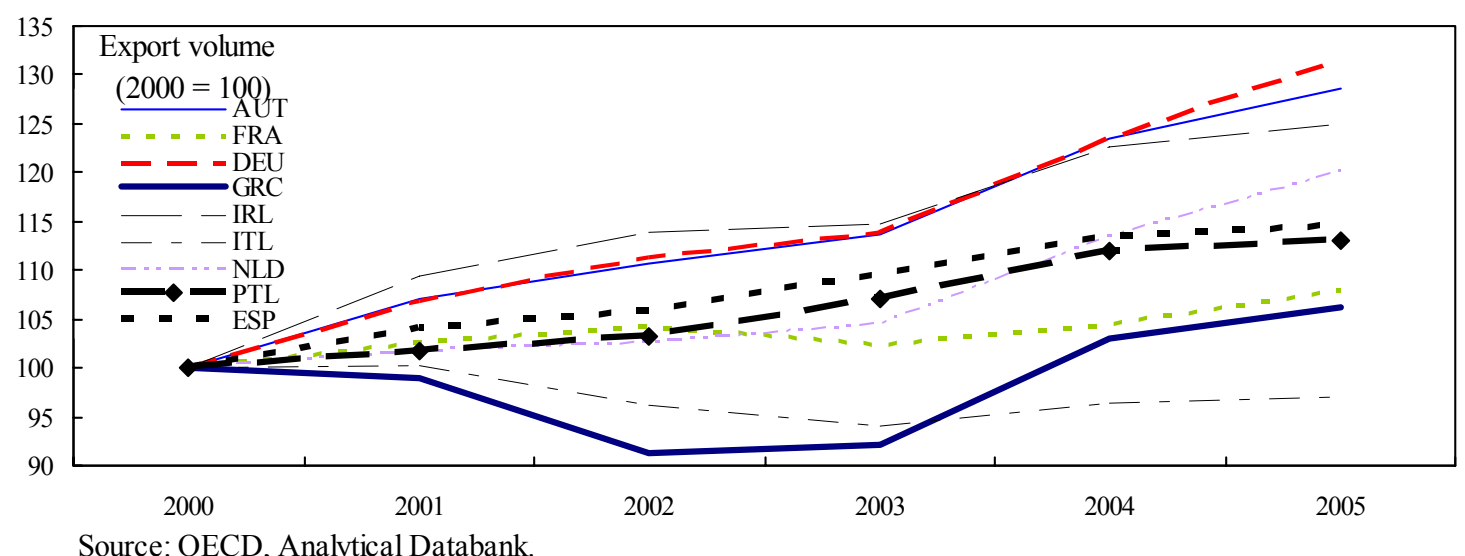

Source: OECD, Analytical Databank.
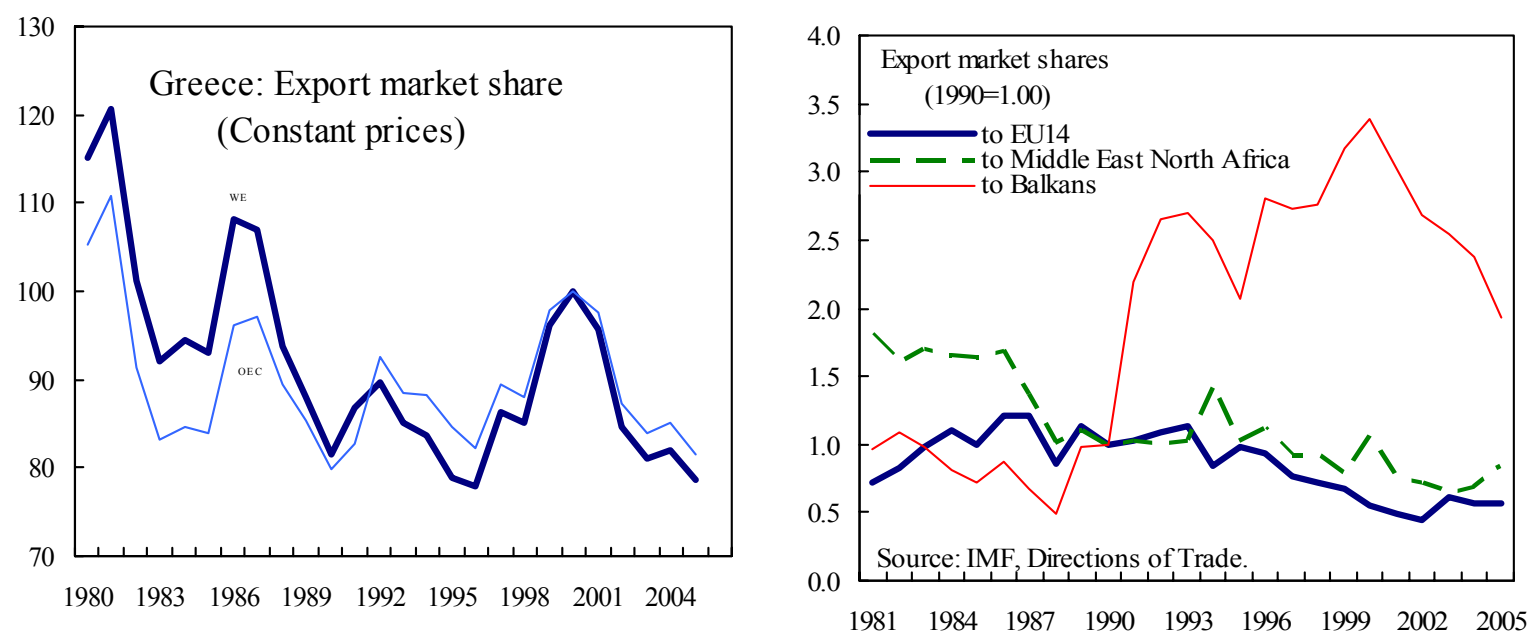

8. The external current account deficit has been high and widening. From the savings-investment perspective, the deficit reflects high investment and low savings rates by international standards. In particular, the recent widening of the deficit reflects mainly an uptick in investment associated with improving economic prospects and a pick-up in infrastructure projects. From a payments perspective, the recent widening of the current account deficit is related to the deterioration in the net income balance (owing to the rise in foreign liabilities, which at 84 percent of GDP at end 2005 are the highest among EMU member countries), and the decline in EU transfers. The terms of trade did not have an appreciable impact on the current account. 
Greece: External Current Account and its Determinants
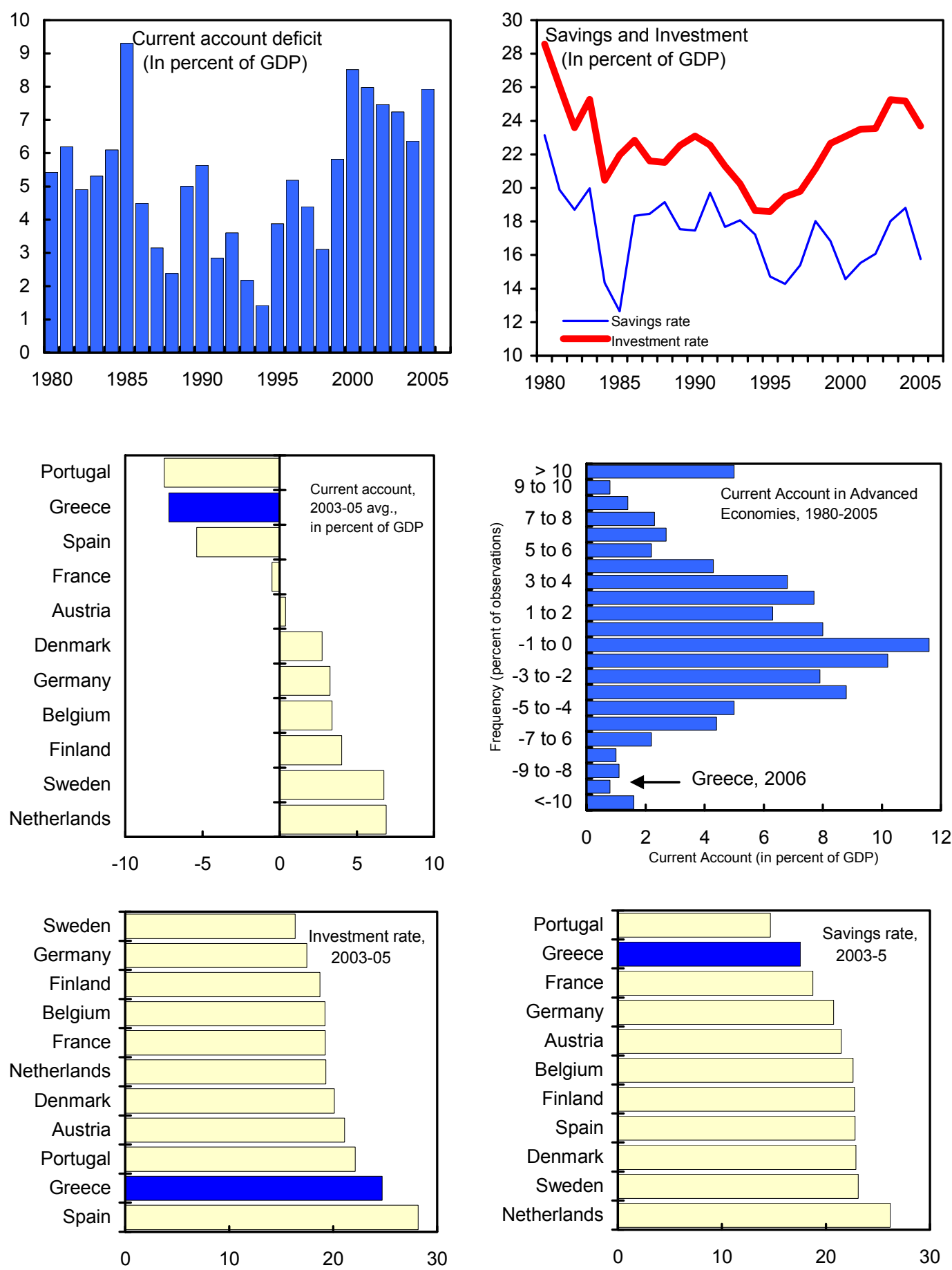

Source: OECD, Analytical Database, and IMF staff calculations. 


\section{The widening of the current account deficit and the real appreciation since}

EMU accession are associated with two demand shocks, the surge in credit growth and fiscal expansion.

- $\quad$ The credit surge is the result of (i) financial liberalization which has relaxed liquidity constraints (especially for households), fostered innovation, and induced banks to aggressively extend credit in their quest for market share, (ii) expectations of higher real estate taxation, which boosted residential construction, and (iii) the drop in real interest rates in the wake of EMU accession, which increased real incomes, improved growth prospects, and raised current expenditure as part of intertemporal consumption smoothing. ${ }^{5}$

- $\quad$ The fiscal expansion, which with the benefit of hindsight was unhelpful from a cyclical perspective, reflects a relaxation following the arduous effort to meet EMU accession criteria, and perhaps difficulty in assessing the cyclical position of the economy at a time of high unemployment.

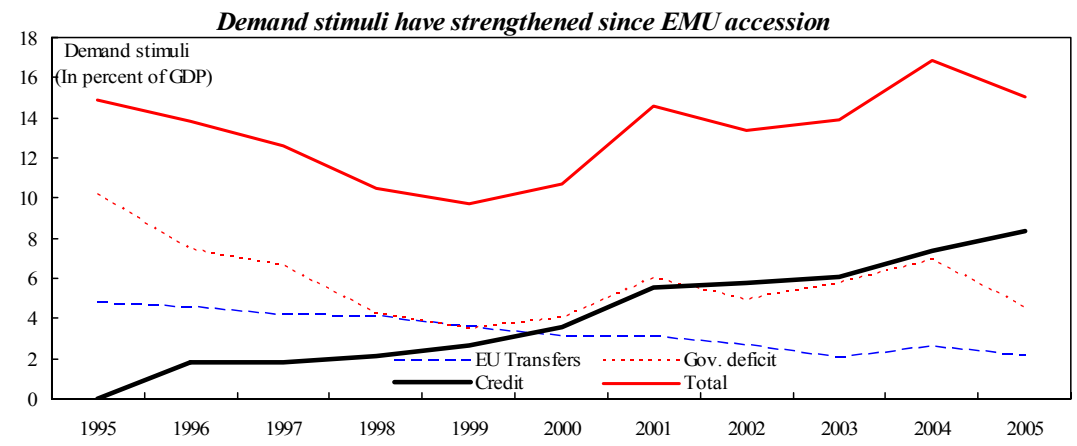

10. However, the demand stimuli are running their course. The ongoing fiscal consolidation, which aims to eliminate the structural deficit by 2010-12, should withdraw stimulus, as will the gradual winding down of net transfers from the EU. Credit growth could remain strong for a while, but will decline as the leverage of the private sector plateaus. Taking other EMU economies as a benchmark, a further increase of the private sector leverage ratio by 30 percentage points of GDP in the next five years would sustain average credit growth at 12 percent per year.

\footnotetext{
${ }^{5}$ Credit to households, the main beneficiaries of financial liberalization, has been growing at almost 30 percent annually and its "contribution" to nominal GDP growth (measured by the ratio of credit expansion over last year's GDP) reached $8 \frac{1}{2}$ percent in 2005 . Although indicative of very easy monetary conditions, this rapid credit expansion is not entirely exogenous as it incorporates the effect of higher growth (actual and prospective), lower real interest rates, etc. Moreover, its impact on aggregate demand has been blunted by the increase in financial asset holdings and the substitution of bank for non-bank credit.
} 
Greece: Demand Stimuli, 1991-2006

The deepening of financial

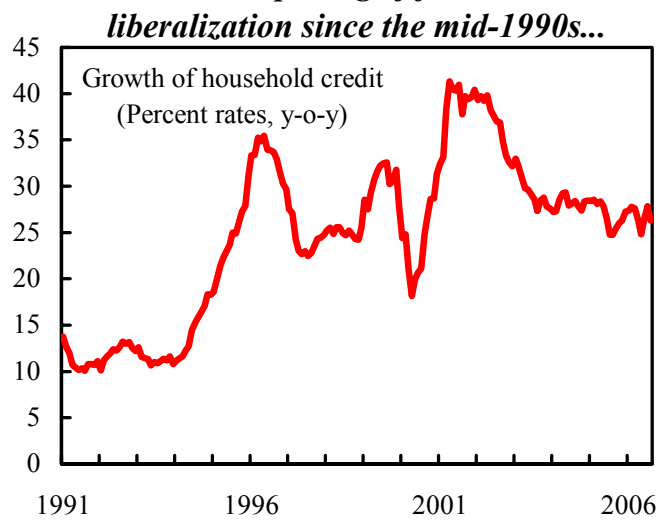

....and the drop of real interest rates

since euro adoption...

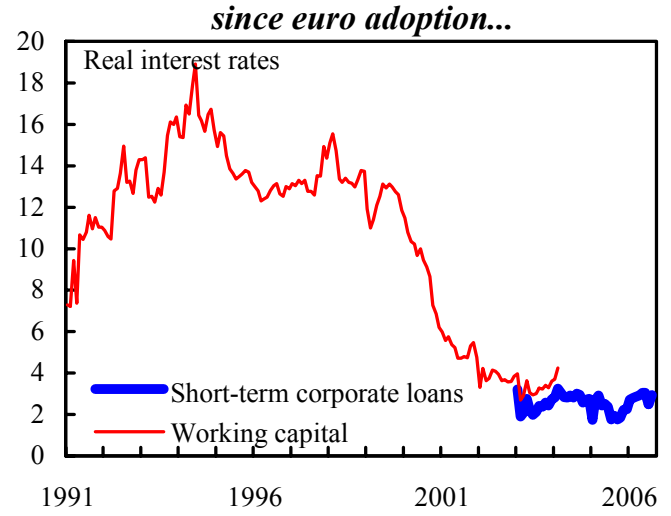

...have made credit expansion to

households an important contributor to

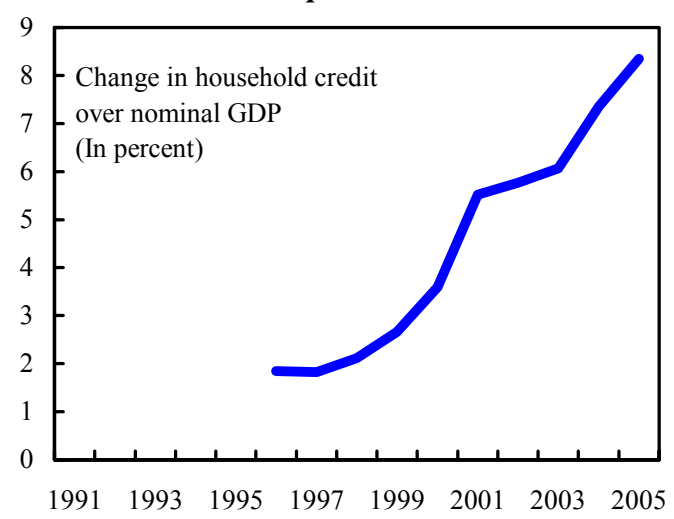

Fiscal consolidation relapsed immediately after euro adoption.

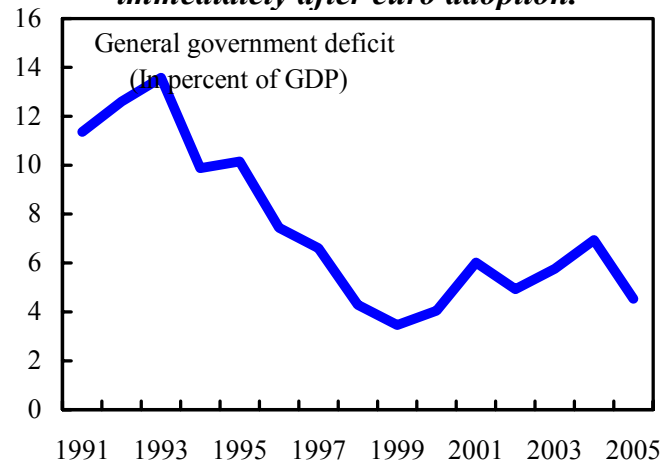

EU transfers remain significant, but declining.

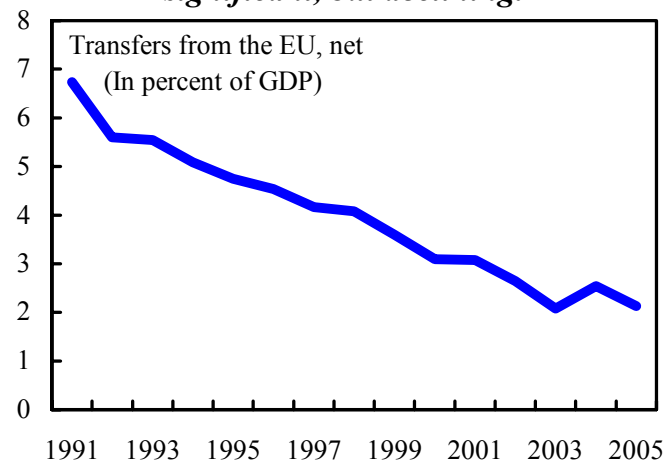

Source: OECD, Analytical Databank; Bank of Greece; IFS, WEO and IMF staff calculations. 


\section{How big is the competitiveness deficit?}

11. The competitiveness deficit is quantified using three methodologies: the Macroeconomic Balance (MB), the Equilibrium Real Exchange Rate (ERER) and the External Sustainability approach (ES). ${ }^{6}$ All three approaches proceed in two steps: first, estimate the gap between external indicators (e.g. current account, effective exchange rate, external indebtedness) from the levels consistent with fundamentals and, then, calculate the exchange rate adjustment needed to eliminate the gap.

\section{The MB approach is based on the gap between the underlying and the} equilibrium current account balance. It then calculates the exchange rate adjustment that would be needed to eliminate this gap using the elasticity of the current account with respect to the real exchange rate.

13. The $\mathrm{CA}_{\mathbf{U}}$ excludes the effect of transitory factors (the cyclical position in Greece and trading partners, temporary changes in the import content of domestic demand, and spikes in freights, oil prices and exports of ships, which are taken to be orthogonal with each other) and is calculated as: ${ }^{7}$

$$
C A_{U}=C A-(M / Y) \psi_{M} Y G A P+(X / Y) \psi_{X} Y G A P F-(D / Y) \alpha\left[(I / Y)-(I / Y)_{\text {avg }}\right]-\text { other one-offs }
$$

where $C A, M, X, I, D$ and $Y$ denote nominal current account, imports, exports, domestic demand, investment and GDP, $\psi_{M}$ and $\psi_{X}$ are the elasticities of imports and exports with respect to activity, $\alpha$ denotes the differential import content in investment relative to consumption, and YGAP (YGAPF) is the domestic (foreign) output gap. A positive output gap driven by domestic demand temporarily raises the current account deficit by raising imports and discouraging exports. Similarly, a negative output gap in partner countries temporarily lowers Greek exports and so raises the current account deficit. Above average investment, owing to its higher import content, also tends to temporarily swell the current account deficit. Net exports of ships are excluded because they relate to the large scale renewal of the mercantile fleet, an operation that is expected to be completed in the next few years. Finally, deviations of freight and oil prices from their trend generate corresponding temporary swings in the current account.

\footnotetext{
${ }^{6}$ These methodologies are discussed in Isard and Faruqee (1998) and Isard et.al. (2001).

${ }^{7}$ See Isard and Faruqee (1998), Chapter V, for a detailed discussion of the methodology of calculating $\mathrm{CA}_{\mathrm{U}}$. The present paper deviates in that it abstracts from lagged exchange rate effects.
} 
Greece: Actual and Underlying Current Account Deficit

(In percent of GDP)

\begin{tabular}{|c|c|c|c|c|c|}
\hline & 2003 & 2004 & 2005 & 2006 & $\begin{array}{r}\text { Change } \\
2003-06\end{array}$ \\
\hline Current account deficit & 7.3 & 6.4 & 7.9 & 9.3 & 2.0 \\
\hline Adjustment & 0.8 & -0.4 & 1.9 & 3.2 & 2.4 \\
\hline Domestic output gap ${ }^{1 /}$ & 0.6 & 1.0 & 1.0 & 1.0 & 0.4 \\
\hline Partners' output gap ${ }^{1 /}$ & 0.2 & 0.1 & 0.3 & 0.3 & 0.1 \\
\hline Import content of domestic demand ${ }^{2 /}$ & 0.8 & 0.8 & 0.4 & 0.3 & -0.6 \\
\hline Deviation of freights from trend ${ }^{3 /}$ & 0.6 & -1.3 & 0.1 & 0.8 & 0.1 \\
\hline Ships & -0.1 & -0.1 & 0.4 & 0.7 & 0.8 \\
\hline Deviation of oil price from trend ${ }^{4 /}$ & -1.4 & -1.0 & -0.3 & 0.2 & 1.6 \\
\hline Underlying current account deficit & 6.5 & 6.9 & 6.0 & 6.1 & -0.4 \\
\hline \multicolumn{6}{|l|}{ Memo item: } \\
\hline Implied overvaluation, in percent & 25 & 28 & 22 & 22 & \\
\hline
\end{tabular}

Source: WEO and IMF staff calculations.

1/ Calculations based on MULTIMOD elasticities as discussed in Isard and Faruqee (1998)

2/ Calculations using import content coefficients as specified in Sideris and Zonzilos (2005).

3/ The calculations sets the baseline for the Baltic Exchange Dry Index at 2,800.

$4 /$ The baseline for the oil price is set at US\$ 60 per barrel.

\section{The underlying current account has averaged 6.3 percent of GDP in recent}

years (see table below). This suggests that the deterioration in the current account reflects primarily cyclical/transitory factors and thus, barring other shocks, the deficit should return to its underlying level of 6 percent of GDP when the transitory factors have run their course. This leads to the question whether a deficit of 6.3 percent is sustainable.

\section{The equilibrium current account $\left(\mathrm{CA}_{E}\right)$ for Greece is estimated at 2.7 percent} of GDP. This estimate is based on the levels of economic fundamentals (fiscal balance, demographics, wealth, oil balance, economic growth, etc) that are expected to prevail in the medium term. The "equilibrium" is of a statistical nature - in the sense that the current account matches the prediction of a reduced form econometric model — and, as such, reflects average behavior of industrial countries. The main factors that underpin the value of the $\mathrm{CA}_{\mathrm{E}}$ for Greece are the high growth rate (i.e. convergence) and population aging.

\section{The gap between $C A_{U}$ and $C A_{E}$ suggests a real overvaluation of about}

24 percent of GDP. ${ }^{8}$ The confidence interval around this estimate is rather wide,

\footnotetext{
${ }^{8}$ The elasticity of the current account with respect to the exchange rate is given by $(X / Y) \eta_{X}+(M / Y)\left(\eta_{M}-1\right)$ where $(X / Y)$ and $(M / Y)$ denote the shares of exports and imports to nominal GDP and $\eta_{X}$ and $\eta_{M}$ the export and
}

(continued...) 
reflecting the fact that the calculations are based on assessments about the cyclical position of the economy at home and abroad, the underlying levels of oil prices and freights, and the equilibrium level of the current account, all of which are difficult to estimate precisely. Robustness checks using alternative assessments of the key parameters suggest a confidence interval of \pm 6 percentage points around the point estimate.

\section{The ERER approach assesses compares the actual to an equilibrium exchange} rate. Intuitively, it assesses whether the real exchange rate appreciation is a benign equilibrium phenomenon that does not require a policy response (for instance, the result of catching up or price level convergence) or the manifestation of external imbalances that need to be rectified (e.g. eroding competitiveness). The equilibrium exchange rate is the one consistent with internal and external balance. Several approaches have been proposed in the literature for defining and estimating the equilibrium exchange rate. ${ }^{9}$ The variant used here estimates it from a panel regression that relates the real effective exchange rate (CPI based) to a set of fundamentals - net foreign assets, productivity differential (Balassa-Samuelson effect), commodity terms of trade, government consumption, trade restrictions, and price controls.

\section{This approach suggest that the exchange rate was about right at the time} Greece acceded to the EMU but has since appreciated, and in early 2006 was 18 percent above the level implied by fundamentals. This overvaluation reflects the appreciation of the REER as well as a fall of the equilibrium rate. The former stems from the higher inflation whereas the latter is driven by the accumulation of net foreign liabilities (NFL), which more than offsets a weak Balassa-Samuelson effect.

import elasticities with respect to the exchange rate. The calculations are based on MULTIMOD elasticities $\left(\eta_{X}=0.71, \eta_{M}=0.92\right)$. The quarterly BoG component (Sideris and Zonzilos, 2005) reports similar long-run elasticites $\left(\eta_{X}=0.6, \eta_{M}=0.9\right)$.

${ }^{9}$ A comprehensive discussion of the different approaches for estimating the equilibrium exchange rate can be found in Driver and Westaway (2204). See also MacDonald (2000, 2006), MacDonald and Stein (1999), and Williamson (1994). 


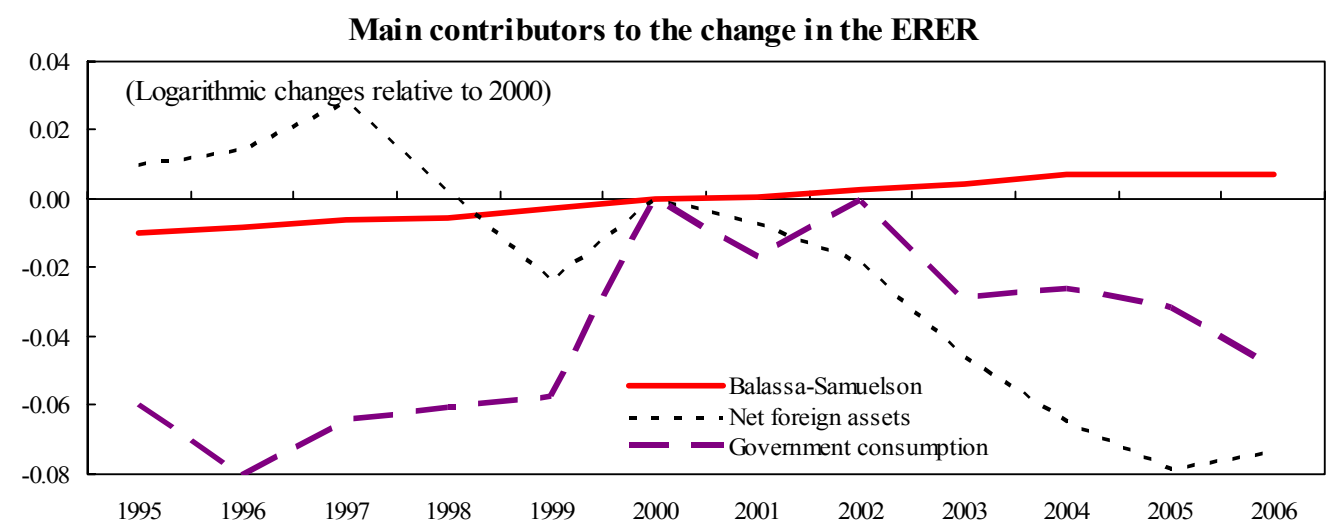

\section{Several factors account for the relative weakness of the Balassa-Samuelson}

effect in Greece. First, the traded goods sector is the smallest among EMU countries and, as a result, does not play a leading role in wage setting. ${ }^{10}$ In fact, the tone for wages is set by the large government sector. As a result, the traded goods sector is forced to adjust employment and raise productivity (including through exit of firms). ${ }^{11}$ Second, the productivity growth differential between the traded and nontraded goods sectors averaged only 2 percentage points in 1995-2003, which is not much higher than in other EMU countries. Finally, a cross-country comparison of the evolution of tradables prices provides evidence that demand stimuli have been driving the real appreciation. The evidence is most clear in the case of audio-visual, photographic and information processing equipment (traded goods par excellence) whose prices in 2000-06 registered the smallest decline in Greece among EMU countries, reflecting the large non-traded component of the price and relatively slow progress in strengthening competition. The decrease was low also in other EMU countries experiencing strong domestic demand.

\footnotetext{
${ }^{10}$ The two cornerstones of the Balassa-Samuelson effect is that the price of tradables are the same at home and abroad and wages are set so as to ensure the competitiveness of the traded goods sector. The latter is assumed to set the tone for the level of wages at home.

${ }^{11}$ In assessing the significance of the Balassa-Samuelson effect it is important to identify whether the productivity growth stems from efficiency gains or from the closure of unprofitable firms. Only the former can support a thriving export sector and raise productivity growth on a sustainable basis.
} 
Change in the prices of audio-visual, photographic, and information processing

(Annual average change, in percent)

\begin{tabular}{lc} 
Austria & -8.8 \\
Spain & -7.3 \\
France & -7.1 \\
Germany & -6.9 \\
Belgium & -6.6 \\
Euro Area & -6.6 \\
Netherlands & -6.4 \\
Finland & -5.7 \\
Ireland & -4.4 \\
Italy & -3.3 \\
Portugal & -3.0 \\
Greece & -1.1 \\
\hline Source: Eurostat, HICP databank &
\end{tabular}

Source: Eurostat, HICP databank.
Greece is the least open among the smaller European economies

\begin{tabular}{|c|c|c|}
\hline & 2001-05 & $1991-95$ \\
\hline & Trade to GDP, a & urrent prices \\
\hline Ireland & 160.3 & 122.9 \\
\hline Austria & 94.7 & 69.9 \\
\hline Denmark & 87.8 & 70.1 \\
\hline Switzerland & 84.3 & 66.3 \\
\hline Sweden & 84.0 & 61.4 \\
\hline Finland & 70.4 & 56.6 \\
\hline Portugal & 65.2 & 61.1 \\
\hline Spain & 56.5 & 38.9 \\
\hline Greece & 51.1 & 43.0 \\
\hline Italy & 50.9 & 40.4 \\
\hline
\end{tabular}

Source: OECD Analytical Database.

\section{The ES approach looks the current account balance from the vantage point of} the sustainability of the country's foreign asset (NFA) position. It consists of three steps: first, it assesses the sustainable level for the net foreign asset position; second, it uses this to determine the current account balance that stabilizes the net foreign asset position at a sustainable level $\left(\mathrm{CA}_{S}\right)$; and finally, it measures the external misalignment by the adjustment in the real effective exchange rate needed to close the $\mathrm{CA}_{\mathrm{U}}-\mathrm{CA}_{\mathrm{S}}$ gap. Unlike the MB and ERER approaches, which rely on econometric estimation, the ES approach requires assumptions about the country's potential growth rate, inflation, and rates of return on external assets and liabilities, as well as an assessment of what constitutes a sustainable level of NFA.

\section{The sustainable current account deficit $\left(\mathrm{CA}_{S}\right)$ is estimated at 3.9 percent of} GDP, which is higher than the $\mathrm{CA}_{\mathrm{E}}$. It is given by: ${ }^{12}$

$$
C A_{S}=-\gamma(1+\gamma)^{-1} N F A_{S}
$$

where $\gamma$ stands for nominal GDP growth and $N F A_{S}$ denotes the sustainable level of the net foreign asset position. In the calculations, $\gamma$ is set at its projected medium-term value of 5.5 percent and $N F A_{S}$ at -85 percent, its level at end-2005 (the highest among EMU countries ${ }^{13}$ ).

\footnotetext{
${ }^{12} \mathrm{CA}_{\mathrm{S}}$ is derived from the equation of motion of NFA under the simplifying assumption of zero valuation effects on NFA and zero transfers.

${ }^{13}$ To some extent, the high net foreign liabilities reflects measurement problems in the numerator and the denominator. Official statistics are unlikely to fully capture real estate and financial assets that Greek residents accumulated abroad prior to financial liberalization; extensive tax evasion continues to contribute to the under-
} 
The sustainable level of NFA is difficult to pin down with precision, especially in the case of an EMU country because the elimination of the country-specific exchange rate risk has made the supply of foreign credits more elastic, eased financing restrictions, and made the level of NFA largely demand determined. ${ }^{14}$ However, the current level of the underlying current account deficit (about 6 percent of GDP) is unlikely to be sustainable, as it implies a rather high steady-state NFA of 115 percent of GDP.

Sensitivity of $\mathrm{CA}_{\mathrm{S}}$ to variations in $\gamma$ and $\mathrm{NFA}_{\mathrm{S}}$

\begin{tabular}{|c|c|c|}
\hline & -75 & -85 \\
\hline $\begin{array}{r}\gamma \\
5.0\end{array}$ & 3.6 & 4.0 \\
\hline 5.5 & 3.9 & 4.4 \\
\hline 6.0 & 4.2 & 4.8 \\
\hline
\end{tabular}

Robustness of the overvaluation estimate

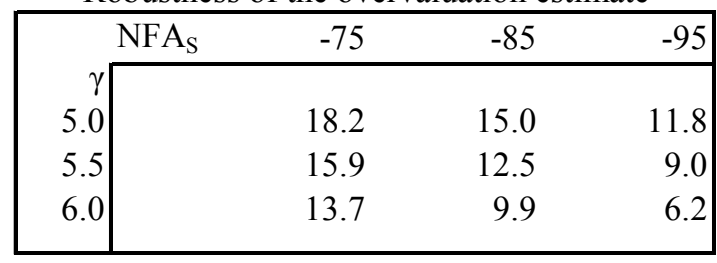

22. The ES approach suggests an overvaluation of $12^{1 / 2}$ percent. ${ }^{15}$ Uncertainty regarding the choices of medium term nominal growth, sustainable NFA, and the elasticity of the current account with respect to the exchange rate imply a margin of error of \pm 6 percentage points around the central estimate.

reporting of foreign assets; and the recent upward revision of the national accounts (which has not been used in these calculations) reduces the ratio of net foreign assets to GDP to 56 percent.

\footnotetext{
${ }^{14}$ Nevertheless, a large rise in external indebtedness would bring increasingly more risky borrowers into the picture raising (at the margin) the cost of borrowing.

${ }^{15}$ The calculations are based on MULTIMOD elasticities, as detailed in footnote 6.
} 


\section{Constant Market Shares Analysis of Competitiveness}

23. The structure of exports changed profoundly during the past decade. There has been a shift of merchandise exports from the EU towards neighboring countries in the Balkans and Turkey. The share of agricultural products and textiles has fallen, while that of services in has risen to 66 percent, more than double that in other EU member countries. ${ }^{16}$ Constant Market Shares (CMS) analysis provides a platform for assessing the extent to which the increase in exports reflects greater penetration of existing markets or a shift towards more dynamic regions/markets.

\section{CMS analysis decomposes the growth in exports $\left(X^{1}-X^{0}\right)$ into four}

components: global market growth, commodity composition, market distribution, and competitiveness (see Annex I):

$$
\begin{aligned}
& X^{1}-X^{0}=r X^{0}+\sum_{i}\left(r_{i}-r\right) X^{0}{ }_{i}+\sum_{i j}\left(r_{i j}-r_{i}\right) X^{0}{ }_{i j}+\sum_{i j}\left(\rho_{i j}-r_{i j}\right) X^{0}{ }_{i j} \\
& \text { Global market growth }+ \text { Commodity composition }+ \text { Market distribution }+ \text { Competitiveness }
\end{aligned}
$$

where $X_{i j}^{t}=$ value of Greek exports of commodity $i$ to country $j$ during period $t$

$r=$ growth rate of world exports

$r_{i}=$ growth rate of world exports of commodity $i$

$r_{i j}=$ growth rate of world exports of commodity $i$ to country $j$

$\rho_{i j}=$ growth rate of Greek exports of commodity $i$ to country $j$

- The global market growth effect (first term) calculates by how much Greek exports rose to keep Greece's share in world trade unchanged. This sets the benchmark against which competitiveness is assessed. A faster increase of exports is prima facie evidence of improving competitiveness.

- The commodity composition effect (second term) examines whether export growth has benefited from the concentration of exports on commodities for which demand has been growing rapidly. It reflects the specialization of the exporting country and the income and price elasticities of demand for its exports.

- $\quad$ The market distribution effect (third term) examines whether export growth has benefited from the concentration of exports in rapidly growing markets/regions.

\footnotetext{
${ }^{16}$ A discussion of long term trends in Greece's external trade can be found in the BoG Annual Report for 2005 (Box IX.2). See also Dimelis (2004, 2004a) and Arghyrou and Bazina (2002).
} 
Changes in the Composition of Greek Exports

The Geographic Composition of Greek Merchandize Exports

\begin{tabular}{|c|c|c|c|c|c|c|c|c|}
\hline \multirow[b]{4}{*}{ Total exports } & & & & & & & 1990-94/ & 2000-05/ \\
\hline & $1960-69$ & $1970-79$ & $1980-89$ & 1990-94 & $1995-99$ & $2000-05$ & $1970-79$ & $1990-94$ \\
\hline & \multicolumn{6}{|c|}{ (Percentage composition) } & \multicolumn{2}{|c|}{ (Change) } \\
\hline & 100.0 & 100.0 & 100.0 & 100.0 & 100.0 & 100.0 & & \\
\hline European Union-15 & 50.0 & 55.2 & 58.8 & 64.6 & 55.0 & 45.1 & 9.3 & -19.4 \\
\hline Euro Area & 42.0 & 49.5 & 51.5 & 56.8 & 47.3 & 36.4 & 7.3 & -20.4 \\
\hline Developing European countries & 26.7 & 18.1 & 11.1 & 14.8 & 26.0 & 33.5 & -3.3 & 18.6 \\
\hline New EU member states & 8.9 & 6.1 & 3.7 & 5.6 & 6.7 & 8.4 & -0.5 & 2.8 \\
\hline Balcans & 7.0 & 5.0 & 2.7 & 4.8 & 9.6 & 13.6 & -0.2 & 8.9 \\
\hline Turkey & 0.2 & 0.5 & 0.8 & 1.5 & 3.1 & 4.3 & 1.0 & 2.9 \\
\hline FSU & 7.3 & 3.5 & 2.2 & 1.8 & 4.0 & 3.4 & -1.6 & 1.6 \\
\hline Non-EU industrial countries & 16.4 & 10.2 & 10.4 & 8.8 & 7.4 & 8.7 & -1.4 & -0.1 \\
\hline USA & 12.2 & 6.4 & 7.2 & 5.0 & 4.3 & 5.5 & -1.4 & 0.5 \\
\hline Africa & 0.9 & 2.7 & 2.9 & 2.0 & 1.8 & 2.4 & -0.7 & 0.4 \\
\hline Asia & 0.3 & 0.6 & 1.3 & 1.5 & 2.3 & 2.8 & 0.9 & 1.4 \\
\hline Middle East & 4.9 & 12.7 & 15.1 & 6.8 & 5.8 & 6.2 & -6.0 & -0.6 \\
\hline Latin America & 0.7 & 0.4 & 0.4 & 1.6 & 1.7 & 1.3 & 1.1 & -0.3 \\
\hline Other & 0.1 & 0.0 & 0.0 & 0.0 & 0.0 & 0.0 & & \\
\hline
\end{tabular}

Sources: IMF, Direction of Trade.

Sectoral composition of Greek Merchandize exports, 1992-2005

\begin{tabular}{|c|c|c|c|c|c|}
\hline & 1992 & 2000 & 2005 & $\begin{array}{r}\text { Change in } \\
1992-2005\end{array}$ & $\begin{array}{r}\text { Market share } \\
\text { in } 2005\end{array}$ \\
\hline & \multicolumn{2}{|c|}{ (Percentage composition) } & & (Change) & $(1992=100)$ \\
\hline Foodstuff & 34.8 & 22.6 & 22.7 & -12.1 & 48.4 \\
\hline Minerals and fuels & 9.4 & 17.9 & 11.9 & 2.5 & 61.4 \\
\hline Chemicals & 3.4 & 7.1 & 12.1 & 8.7 & 107.1 \\
\hline Raw materials & 7.9 & 7.1 & 9.2 & 1.2 & 56.3 \\
\hline Textiles & 28.6 & 20.5 & 15.6 & -13.0 & 28.0 \\
\hline Metals & 9.9 & 9.9 & 13.1 & 3.2 & 47.6 \\
\hline Manufacturing items & 4.2 & 10.6 & 10.6 & 6.4 & 78.3 \\
\hline Transportation equipment & 0.8 & 2.3 & 2.8 & 2.0 & 133.4 \\
\hline Other manufacturing items & 0.9 & 2.0 & 1.9 & 1.0 & 73.4 \\
\hline Total & 100.0 & 100.0 & 100.0 & & 39.8 \\
\hline
\end{tabular}

The share of services in total exports has been increasing...



....and is the highest among OECD countries

\begin{tabular}{ll}
\multicolumn{2}{c}{$\begin{array}{c}\text { Share of services in } \\
\text { exports (2003-05) }\end{array}$} \\
\hline Greece & 66.5 \\
United Kingdom & 34.9 \\
Ireland & 34.1 \\
Spain & 32.1 \\
Austria & 31.5 \\
Portugal & 28.2 \\
Sweden & 23.7 \\
France & 21.0 \\
Italy & 19.4 \\
Netherlands & 19.0 \\
Belgium & 17.7 \\
Germany & 13.9 \\
Finland & 13.5 \\
\hline
\end{tabular}


- $\quad$ The competitiveness effect (fourth term) captures changes in export market share after adjusting for the impact of the other effects. That is, it is the residual. Moreover, it is assumed to be independent of the other effects and is taken to reflect largely exchange rate developments and the role of domestic factors in the exporting country such changes in the quality and composition of exports. When trade flows are in nominal terms (as it is the case with the Comtrade databank used here) the competitiveness effect also incorporates the effects of terms of trade changes.

Greece: CMS Analysis of Exports Changes

(Value in billion US dollars; unless otherwise indicated)

\begin{tabular}{lrr}
\hline & $1992-2005^{1 /}$ & $2000-2005^{2 /}$ \\
\hline Change in exports & & \\
$\quad$ in bln US\$ & 7.5 & 6.3 \\
Average annual growth rate (in percent) & 4.5 & 9.8 \\
& & \\
Due to: & & 6 \\
World Trade Effect & 33 & -1 \\
Commodity Composition Effect & -9 & 3 \\
Market Distribution Effect & 11 & -1 \\
Competitiveness effect & -27 & \\
\hline
\end{tabular}

Source: Comtrade databank and IMF staff estimates.

${ }^{1 /}$ Based on the commodity composition of exports in 1992.

${ }^{2 /}$ Based on the commodity composition of exports in 2000.

\section{The results of the CMS calculations for Greece can be summarized as: ${ }^{17}$}

- The growth of Greek merchandise exports in 2000-05 is explained largely by rising world trade, with the competitiveness effect having only a small, though negative effect. In contrast, in 1992-2000 export growth fell well short of what would be expected from world trade developments (that is, market share was lost), implying a large competitiveness (residual) loss. ${ }^{18}$ In view of the significant REER appreciation since 2000, the small loss of market share suggests that chronic problems in export sectors are being rectified.

\footnotetext{
${ }^{17}$ Calculations are based on the UN Comtrade (Commodity Trade Statistics) database using annual data for the period 1992-2005. Commodities are grouped in nine categories (food, mineral fuels, chemicals, raw materials, textiles, metals, manufacturing items, transportation equipment, and other manufacturing goods) and export markets in 13 regions (Germany, Italy, UK, France, Spain, Cyprus, Rest of EU15, USA, Turkey, Bulgaria, Romania, Albania, and the rest of the world).

${ }^{18}$ This negative competitiveness effect is consistent with econometric evidence, based on longer samples, which suggest a below unity elasticity of exports with respect to world demand (Zonzilos, 2006).
} 
- $\quad$ The negative commodity composition effect, though very small for the recent period, indicates that Greek exports are tilted towards items for which world demand has been growing at below average rates.

- The positive market distribution effect reflects that the rapidly expanding southeastern European economies have been a significant driver for Greek exports, although again less so in recent years.

- The negative competitiveness effect indicates a significant erosion of competitiveness. The bulk of the this erosion occurred in the 1990s when the Greek economy was slow to take advantage of the opportunities opened up by increasing globalization and the surging imports of emerging market economies. Since the euro adoption there has been a further small loss of export market share that is consistent with the appreciation of the real effective exchange rate.

26. Several caveats apply to these conclusions. First, the analysis excludes services exports, which are double the size of merchandise exports. Moreover, the erosion of competitiveness could be underestimated by the rapid expansion in recent years of intraindustry trade with neighboring Balkan countries. Finally, the analysis is based on values and, thus, cannot distinguish between volume and price effects.

\section{E. Should external imbalances be of concern in a euro-area country?}

\section{Adoption of the euro has reduced the significance of the current account} deficit and external indebtedness as risk factors. First, there are statistical measurement problems, shared by all EMU member countries: the deepening of economic and financial integration is making it increasingly more difficult to capture trade and financial flows visà-vis other EMU countries. In Greece, an additional complicating factor is still extensive tax evasion and the large underground economy. ${ }^{19}$ Second, and more important, the elimination of country-specific exchange rate risk has made the supply of foreign financing elastic and CA and NFA largely demand determined. In such an environment, and to the extent that the economy is free of distortions - external borrowing is contracted mainly by the private sector and is based on capacity to repay, risks are correctly priced, prices are flexible, and the corporate and household balance sheets are sound - the current account deficit and external indebtedness are equilibrium outcomes that reflect primarily time preferences and expectations of future income. All this does not mean, however, that endogenous adjustment will not eventually occur, and the key policy issue is how best to ensure a smooth unwinding of imbalances.

\footnotetext{
${ }^{19}$ New national accounts data, which capture better the underground economy, revised the 2005 current account deficit from 8 percent to 6 percent and the IIP from 82 percent to 65 percent.
} 
Evolution of Greece's net International Investment Position

\begin{tabular}{lrrrr}
\hline & 2002 & 2003 & 2004 & 2005 \\
\cline { 2 - 5 } Private sector & \multicolumn{4}{c}{ (In percent of $G D P$ ) } \\
Direct investment & $-\mathbf{1 5}$ & $\mathbf{- 1 1}$ & $\mathbf{- 8}$ & $\mathbf{- 9}$ \\
Portfolio investment & 4 & -5 & -6 & -7 \\
Other investment & -15 & -13 & -9 & 12 \\
Goverment bonds & $\mathbf{- 4 4}$ & $\mathbf{- 5 1}$ & $\mathbf{- 6 7}$ & $-\mathbf{- 7 4}$ \\
Reserves & $\mathbf{6}$ & $\mathbf{3}$ & $\mathbf{1}$ & $\mathbf{1}$ \\
Total & $\mathbf{- 5 3}$ & $\mathbf{- 5 9}$ & $\mathbf{- 7 4}$ & $\mathbf{- 8 2}$ \\
\hline
\end{tabular}

Source: IMF, IIP databank.

\section{Greece's recent high current account deficits have not encountered financing}

problems. Enterprises have relatively small net foreign liabilities (see table above) and encounter no difficulty in attracting external financing, and the banking system is sound. In addition, households have large real estate holdings that can used to finance current consumption. Moreover, external deficits have been financed almost exclusively by running down assets (mainly holdings of government securities) at a time when international financial markets were generously endowed with liquidity and the ratings of Greek government securities were raised. ${ }^{20}$ As a result, the bulk of external indebtedness comprises government securities. About $1 / 4$ of these securities have remaining maturity of less than 2 years, a short maturity that creates vulnerability because in the event of turbulence in international financial markets. Lengthening the maturity of public debt or, preferably, creating propitious conditions for replacing public debt by foreign direct investment could mitigate this vulnerability.
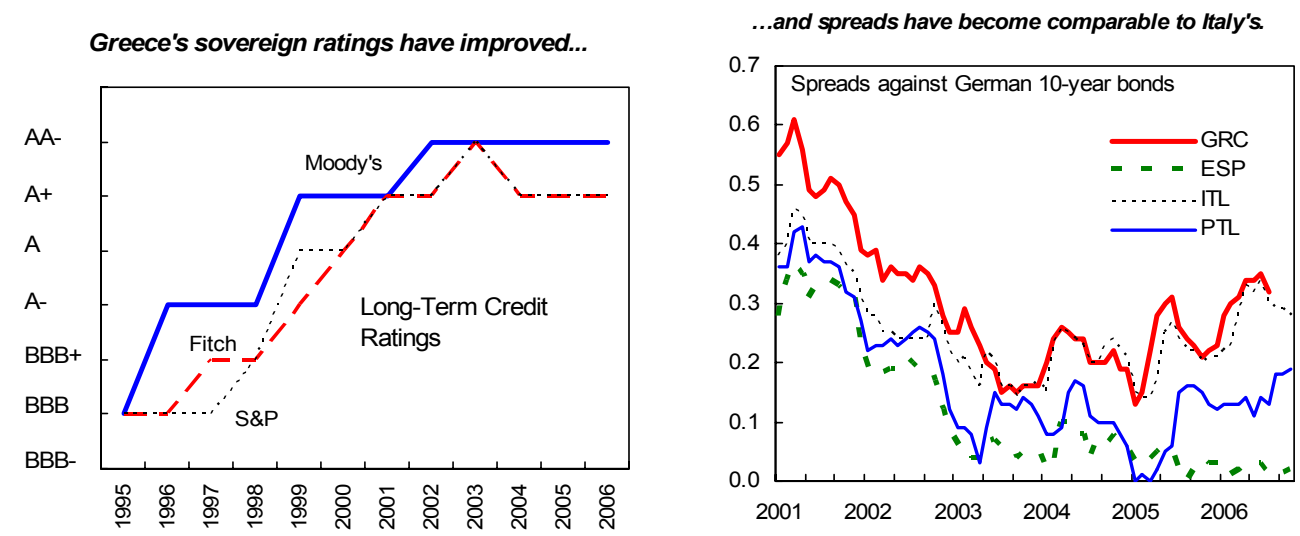

\footnotetext{
${ }^{20}$ According to preliminary flow of funds data, the decumulation of assets reflects banks' running down of their government securities holdings to finance more profitable credit expansion. Households' net financial position has declined very little, as the increase in bank borrowing was largely offset by an increase in households' financial assets.
} 
29. A real appreciation could pose serious challenges for euro-area economies. If the appreciation is unsustainable (in the sense of being inconsistent with the expected evolution of fundaments) and nominal wages are characterized by downward rigidity, there is need for policy action: with exchange rate realignment not an option, a large real depreciation may necessitate a correspondingly large real wage contraction to bring ULC growth below that in euro-area partners. For example, the elimination of an 18 percent real overvaluation (the average of the estimates in Section C) requires a 5 year long nominal freeze. ${ }^{21}$ Wage restraint of this order is unlikely to happen without a deep recession.

\section{The factors that have been boosting domestic demand in recent years are} running their course. In particular, when financial liberalization matures and households' indebtedness approaches its new higher equilibrium level, consumption growth will decelerate towards its new steady-state level, ${ }^{22}$ and will accordingly dent GDP growth. The decline in growth could be averted by replacing faltering domestic demand with exports. But this will require a reduction in the relative price of nontradables so as to (i) facilitate the transfer of productive resources to the export sector and (ii) restore the competitiveness of the export sector. Box 1 sketches the adjustment of a small open economy to a demand shock. ${ }^{23}$

\footnotetext{
${ }^{21}$ The calculation assumes that productivity in Greece remains on its current trend and wage moderation continues in the rest of the euro area. In this scenario nominal wages take the brunt of the adjustment. Supportive structural policies can take off some pressure from wages. For example, if structural reforms and capital deepening raise productivity growth by 1 percentage point to $3 \frac{1}{2}$ percent per year, the adjustment period will be shortened to $4 \frac{1}{4}$ years.

${ }^{22}$ The new level of steady-state consumption is lower than the current rate and roughly equal to productivity growth plus population growth.

${ }^{23}$ See Blanchard (2006a) for a similar analysis based on an optimizing model. In related work, Krugman (1987) argues that a long period of low production may permanently lower productivity and emphasizes the role of external learning by doing.
} 


\section{Box 1. A Simple Model of Internal and External Adjustment}

The gist of adjustment can be captured by a simple IS model:

$$
y=D D(y, s)+N X(\varepsilon, y)
$$

where $y$ stands for output, $D D(.$.$) denotes domestic demand, and is assumed to be an increasing function$ of output and an index of fiscal policy, $g$, and a demand shock, $s ; N X(\ldots)$ is net exports, assumed to be a decreasing function of the real exchange rate, $\varepsilon$, and output. Internal balance requires that $y=y^{*}$, where $y^{*}$ is potential output. External balance requires $N X(\ldots)=0$. The model is closed with a Phillips curve, which stipulates that internal imbalance leads to higher inflation and to real appreciation.

The relations are plotted in the figure below, with the real exchange rate on the vertical axis and output on the horizontal axis. The $I S$ curve is drawn for given values of $g$ and $s$ and is downward sloping: an appreciation decreases the equilibrium level of output. The internal balance is vertical at $y=y^{*}$. To the right of $y^{*}$, the real exchange rate appreciates and the economy moves up along the $I S$ curve. To the left of $y^{*}$, the real exchange rate depreciates and the economy moves down along the IS curve. The external balance is given by the $N X=0$ curve and is downward sloping and flatter than the $I S$ curve (because the marginal propensity to spend is less than one). Let the economy be in internal and external equilibrium at point A.

Now suppose that a shock (say, financial liberalization) raises domestic demand. This will shift the IS curve to the right to $I S$ ', while the $N X=0$ locus remains unchanged; and will bring the economy to A'. At this point, output is above potential and external trade in deficit. If the economy is left to run its course unhindered, inflation will increase, the real exchange rate will appreciate and the trade deficit will widen. The economy will move along the $I S$ ' curve and eventually reach A'. At this point, output is back at potential but the real exchange rate is overvalued, the trade balance in deficit, the IIP worse than in the initial equilibrium (due to the accumulation of external deficits). The servicing of external debt will reduce disposable income, lead to a contraction of domestic demand, reduce output below potential and put in motion a competitive disinflation. The contraction of demand will eventually take the economy, along path A"A, to the original equilibrium. The adjustment will be faster if the demand shock weakens over time.

\section{This boom-bust cycle could} have been attenuated with a

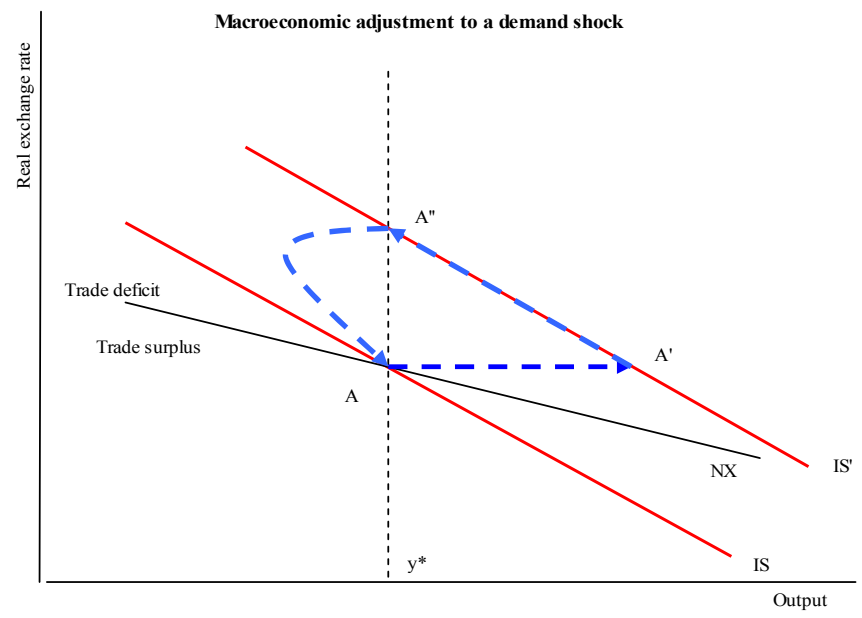
fiscal contraction at the

beginning of the cycle. Although the real appreciation is an equilibrium phenomenon, the case for policy intervention can be made on the fact that the costs of departures from potential output are not symmetric. They are higher when the economy is below potential. Also, costs are smaller when the economy is growing rapidly (the adjustment requires a growth recession) than slowly (the adjustment may require stagnation or even contraction of output). 


\section{F. How could the lost competitiveness be clawed back?}

\section{Several channels can help recover competitiveness, in the absence of a} nominal exchange rate depreciation. Wage restraint lowers ULC and, to the extent that it reduces domestic absorption, facilitates the transfer of resources to exportables. Structural reform raises productivity growth, lowering ULC and raising potential growth. Fiscal consolidation eases inflationary pressures, thereby lowering ULC growth and, by reducing absorption, facilitates the transfer of resources to the export sector. Finally, the recovery of competitiveness will be assisted also by the fading of the financial liberalization shock and possible wealth effects (for instance, social security funding or asset price corrections).

\section{The almost 20 percent competitiveness deficit is too large to be eliminated} within a reasonably short period via any single channel. Policy intervention on a broad range of areas and policy complementarities will shorten the adjustment period and ameliorate side effects.

- Wage restraint. Any effective strategy of restoring competitiveness needs to reduce ULC growth below that in euro-area countries. Restraining nominal wage growth to productivity growth plus euro area inflation would stop further widening of the competitiveness gap, but would not close it. ${ }^{24}$ To illustrate how the effect of wage growth on closing the gap, consider the following examples. A nominal wage freeze would take 5 years to eliminate the competitiveness deficit. It would take twice as long with nominal wage growth of 2 percent a year, that is, zero real wage growth at the ECB's inflation target. Wage restraint of this order is not feasible in the absence of a deep recession.

- $\quad$ Structural reforms can significantly reduce the need for wage restrain by cutting labor costs and raising potential growth. They operate primarily through two channels, the reduction of labor costs and the increase in potential growth. Reforms can boost labor productivity and dent inflation (by strengthening competition and align wages better with productivity). For example, a rise in productivity growth by 1 percentage point and a decline of inflation by 0.3 percentage points (a temporary effect lasting only while competition intensifies) would shorten the time needed to eliminate the competitiveness gap by $1 \frac{1}{2}$ years. Potential growth is increased by

\footnotetext{
${ }^{24}$ The above calculations refer to average wages. Actual wage settlements should ideally be guided by productivity and demand conditions in each individual industry. Wage restraint can be effected through fiscal policy and, in particular, by showing restraint in setting the public sector wage bill. This is of particular importance in Greece, where the public sector is large and sets the tone in wage negotiations.
} 
aggregate productivity increases, but also through improved non-price competitiveness that allows a shift in production to higher-value items. Higher potential growth would, in turn, permit deflationary pressures (an output gap) to arise while still maintaining acceptable actual growth.

- $\quad$ Export growth. The current account can be brought to its fundamental or sustainable level through higher import growth. To illustrate, eliminating 3 percentage points of current account deficit within five years would require 4.2 percent ( \pm 0.7 percent) higher export growth. ${ }^{25}$ The broad based rebound of exports in 2005-06 suggests that faster export growth is feasible if the world economy continued to grow at its current fast pace, although sustaining such a performance for 5 years would be a challenge. The removal of administrative impediments to exports and active export promotion would help, as would structural policies that facilitate the reallocation of resources from the non-traded to the traded sector and eliminate bottlenecks.

Additional export growth needed to close the gap
\begin{tabular}{|rccr|}
\hline CA adjustment & 2.5 & 3 & 3.5 \\
\hline$\gamma$ & & & \\
4.5 & 3.5 & 4.1 & 4.7 \\
5.5 & 3.5 & 4.2 & 4.8 \\
6.5 & 3.6 & 4.2 & 4.9 \\
\hline
\end{tabular}

- $\quad$ Higher net savings. From the savings-investment perspective, the current account deficit could be cut by increasing cyclically adjusted net savings. The authorities announced medium-term fiscal consolidation target implies a reduction in the cyclically adjusted deficit by about 3 percent of GDP. Private savings could rise as the effects of financial liberalization and lower interest rates on euro adoption wane. Other factors, such as concerns about the viability of the social security system could also raise the savings rate. Finally, external adjustment could be supported also by the discouragement of investment from the real effective appreciation.

\section{Depending on the constellation of policies and luck, adjustment might follow} three alternative scenarios:

- In the good scenario, lost competitiveness is clawed back without the economy having to go through a recession. This presupposes the gradual unwinding of the demand stimuli and strong policy bundle comprising fiscal consolidation, structural reforms, wage moderation, and strong financial oversight.

\footnotetext{
${ }^{25}$ The calculation assumes that the import content of exports is 30 percent. An import content of 40 percent would necessitate a further acceleration of exports by $1 \frac{1 / 2}{2}$ percentage points.
} 
- $\quad$ The bad scenario involves a hard landing triggered by a sudden unwinding of the demand stimuli and accumulated vulnerabilities. A weak fiscal situation (that is, a fiscal deficit close the Maastricht threshold) would limit the scope for the automatic stabilizers while the overvaluation and structural rigidities would prevent an offsetting increase in exports.

- In the ugly scenario, the hard landing is exacerbated by financial sector problems. A sudden economic slowdown might reveal banking-sector vulnerabilities that have heretofore been masked by strong growth (these are hypothetical, as the banking sector appears to be strong by the usual indicators). A resulting contraction of credit would exacerbate the downturn.

34. What can we learn from other countries? A relevant and instructive episode from Europe is the recent hard landing of the Portuguese economy. A sharp drop in interest rates and expectations of faster growth - both, as is the case in Greece, triggered by the prospects of EMU accession - led to a decrease in private savings and an investment boom. The result was fast output growth, rising wages, real appreciation, and widening current account deficits. However, the investment boom came to an end, and with disappointed expectations, private savings increased. Countercyclical fiscal policy could not prevent the slump. ${ }^{26}$ The main lessons from the Portuguese experience are the importance of having a strong fiscal position to allow automatic stabilizers to operate fully when the demand stimulus unwinds, withdrawing some stimulus during the "lending boom" phase of the cycle to temper the subsequent size of adjustment, and pursuing structural reform.

\section{The growth cycle in Greece shares many common elements with the}

Portuguese one. Important similarities include the rapid growth in credit and domestic demand, the large real effective appreciation, the widening current account deficit, and a weak fiscal situation. However, other factors work to Greece's advantage. The private sector is less leveraged and real estate price increases have been less extreme, suggesting smaller vulnerabilities. Productivity has been growing fast, compared to stagnation in Portugal, and the recent attention to improving the business climate should bolster productivity further. And the fiscal situation has recently improved; if this is sustained, fiscal room to maneuver may be enough to help stabilize the economy in the event of an adverse shock. These considerations provide hope that the "good scenario" will prevail over the medium term.

\section{Restoring external competitiveness will require concerted action on four} fronts:

\footnotetext{
${ }^{26}$ See also Blanchard $(2006,2006 a)$ and Fagan and Gaspar (2005).
} 
- Wage restraint, especially in the public sector, which sets the tone for national wage negotiations.

- $\quad$ Structural reform, to boost productivity, lower inflation (by strengthening competition and improving the wage bargaining process), and create an environment that nurtures innovation and encourages specialization in less price sensitive products.

- $\quad$ Fiscal consolidation, to alleviate current appreciation pressures and allow room for automatic stabilizers to operate fully when the demand shock dissipates.

- $\quad$ Proactive and forward looking prudential oversight, to safeguard financial stability. 


\section{Annex I. Derivation of the CMS Decomposition}

The decomposition of the change in exports $\left(X^{l}-X^{0}\right)$ is derived as follows:

$$
\begin{aligned}
& X^{1}-X^{0}=\sum_{i j} \rho_{i j} X^{0}{ }_{i j}= \\
& =r X^{0} \\
& =r X^{0}+\Sigma_{i} r_{i} X_{i}^{0}-\Sigma_{i} r_{i .} X^{0}{ }_{i} \\
& =r X^{0}+\Sigma_{i}\left(r_{i} X^{0}{ }^{-} r X_{i}^{0}\right) \\
& =r X^{0}+\Sigma_{i}\left(r_{i}-r\right) X^{0}{ }_{i}+\sum_{i j} r_{i j} X^{0}{ }_{i j}-\sum_{i j} r_{i j} X^{0}{ }_{i j}-\Sigma_{i j} r_{i} X^{0}{ }_{i j}+\Sigma_{i j} \rho_{i j} X^{0}{ }_{i j}= \\
& =r X^{0}+\Sigma_{i}\left(r_{i}-r\right) X^{0}{ }_{i}+\Sigma_{i j}\left(r_{i j}-r_{i}\right) X^{0}{ }_{i j} \quad-\Sigma_{i j} r_{i j} X_{i j}^{0}+\Sigma_{i j} \rho_{i j} X^{0}{ }_{i j}= \\
& =r X^{0}+\Sigma_{i}\left(r_{i}-r\right) X^{0}{ }_{i}+\sum_{i j}\left(r_{i j}-r_{i}\right) X^{0}{ }_{i j}+\sum_{i j}\left(\rho_{i j}-r_{i j}\right) X_{i j}^{0}
\end{aligned}
$$

An early statement of the CMS methodology can be found in see Richardson, D. 1971, "Constant-Market-Shares Analysis of Export Growth", Journal of International Economics, 1, pp. 227-239. For alternative formulations and refinements of the methodology, see Milana, C. 1988, "Constant-Market-Shares Analysis and Index Number Theory", European

Economy, Vol. 4, pp. 453-478 


\section{REFERENCES}

Arghyrou, M. and E. Bazina, 2002, "Competitiveness and the External Trade Performance of Greece in the 1990s,” Public Policy Discussion Paper 02-06, Brunel Business School, Brunel University.

Blanchard, O.,2006, “Adjustment with the Euro. The Difficult Case of Portugal,” MIT Working Paper 06-04

Blanchard, O.,2006a, "Current Account Deficits in Rich Countries," Mundell-Fleming Lecture delivered at the IMF's $7^{\text {th }}$ Jacques Polak Annual Research Conference.

Dimelis, S., 2004, "Comparative Advantages of the Greek Economy: An Aggregative and Sectoral Analysis," Center of Planning and Economic Research, Studies 53.

Dimelis, S., 2004a, "Prospects for the Greek economy in the Post-Enlargement Era," The World Economy, Vol. 27, No. 6, pp. 803-827.

Driver, R. L., and P. F. Westaway, 2004, “Concepts of Equilibrium Exchange Rates,” Bank of England Working Paper No. 248, London.

Fagan, G. and V. Gaspar (2005), "Adjusting to the Euro Area: Some Issues Inspired by the Portuguese Experience," mimeo

Isard, P. and H. Faruqee (1998), "Exchange Rate Assessment: Extension of the Macroeconomic Balance Approach”, IMF Occasional Paper 167

Isard, P., R. Kinckaid, M. Fetherstone and H. Faruqee (2001), "Methodology for Current Account and Exchange Rate Assessments," IMF Occasional Paper 209

MacDonald, R., and J. L. Stein, 1999, Equilibrium Exchange Rates, Massachusetts: Kluver Academic Publishers.

MacDonald, R., 2000, "Concepts to calculate Equilibrium Exchaneg Rates: an Overview," Economic Research Group of the Deutsche Bundesbank, Discussion Paper 3/00.

MacDonald, R., 2006, The Economics of Exchange Rates: Theories and Evidence, Taylor and Francis, forthcoming.

Pesola, J. (2001), “The Role of Macroeconomic Shocks in Banking Crises,” Bank of Finland Discussion Paper 6.2001 
Reisen, H., 1998, "Sustainable and Excessive Current Account Deficits," OECD

Development Centre Working Paper No. 132

Sideris, D and N. Zonzilos (2005), "The Greek Model of the European System of Central Banks Multi-Country Model”, Bank of Greece Working Paper 20

Williamson, J., 1994, Estimating Equilibrium Exchange Rates, Washington DC, Institute for International Economics 


\section{GReECE's Fiscal AdJUSTMENT In AN InTERNATIONAL CONTEXT? ${ }^{27}$}

\section{A. Introduction}

1. While the boldness of fiscal adjustment is often assessed in terms of the targeted fiscal balance, international evidence suggests the composition of the adjustment is key to successful and durable results. Alesina and Perotti (1995 and 1996) show that permanent improvements in the fiscal balance are implemented mainly through cuts in transfer programs and compensation of government employees. Temporary adjustments rely instead on tax hikes and cuts in investment programs. When embarking in fiscal consolidation, a key issue is therefore to identify the components of the budget, both on the expenditure and revenue side, that are most likely to deliver durable adjustment.

2. The Hellenic Stability and Growth Program for 2005-08 commits the Greek government to implement substantial reforms, including fiscal consolidation, to improve the competitiveness of the economy. But how does this strategy, including the portion that has already been implemented, compare with the "received wisdom" of international experience?

3. This chapter looks first at whether the lessons from international experience are still valid. To this end, it updates the empirical literature by looking at more recent cases of fiscal consolidation in several developed economies. It then considers the characteristics of the fiscal adjustment (already implemented and still to be implemented) by the Greek authorities. It concludes with an assessment of how well Greece's fiscal strategy conform to the stylized facts emerging from the analysis of the international experience.

\section{B. Methodology}

4. The first step is to develop a measure of the fiscal stance (fiscal impulse). There are various measures of fiscal stance that try to gauge the discretionary component of fiscal policy. Following Blanchard (1993) budget expenditures and revenues are estimated net of built-in stabilizers and progressivity in the tax system. In practice, the measure is constructed, for each country, (i) by regressing social transfers (as share of GDP) onto a constant, a trend, and the unemployment rate; and (ii) using the regression's estimated coefficients and residuals, by calculating the level of transfers that would have prevailed had unemployment remained the same as in the previous year. The same procedure is applied to total revenues. The measure of fiscal impulse is then calculated as the difference

\footnotetext{
${ }^{27}$ Prepared by Marco Rossi (EUR).
} 
between the unemployment-adjusted measure of the primary deficit and the previous year's primary deficit.

5. The second step is to identify episodes of fiscal adjustment and qualify them. For this, an arbitrary threshold level for the fiscal impulse is set, which characterizes the fiscal adjustment as "tight" or "very tight". Following Alesina and Perotti (1995), the fiscal adjustment, for any given year and for any given country, is defined according to the fiscal impulse $\left(\mathrm{FI}_{\mathrm{i}}\right)$ as follows:

$$
\begin{aligned}
& \text { - } \quad \text { Tight if }\left(\mu_{\mathrm{i}}-\sigma_{\mathrm{i}}\right) \leq \mathrm{FI}_{\mathrm{i}} \leq\left(\mu_{\mathrm{i}}-0.5 \sigma_{\mathrm{i}}\right) \\
& \text { - } \quad \text { Very tight if } \mathrm{FI}_{\mathrm{i}}<\left(\mu_{\mathrm{i}}-\sigma_{\mathrm{i}}\right)
\end{aligned}
$$

where $\mu_{\mathrm{i}}$ and $\sigma_{\mathrm{i}}$ denote, respectively, the average and the standard deviation of the change in the unemployment-adjusted primary deficit for country $i^{28}$

\section{The third step is to identify the episodes of fiscal adjustments that have been} successful - that is, sustained. Again, an arbitrary threshold for the value of the unemployment-adjusted fiscal deficit in the years following the adjustment is set. Specifically, a fiscal adjustment is deemed successful if the average of the unemploymentadjusted fiscal deficits over the three years following the adjustment is 2 percent or 1 percent below the level it had the year preceding the adjustment, according to whether the fiscal stance during the adjustment is defined tight or very tight, respectively.

\section{The analysis is completed by looking at the characteristics of the fiscal} adjustment, including the type of expenditure cuts and revenue increases specifically in relation to whether the adjustment proved successful or not.

\section{Recent Experiences}

8. The source for the data is the OECD. The data set spans 30 countries over the period 1990-2004. Information is not available for all series and all countries, which reduces the number of observations on $\mathrm{FI}_{\mathrm{i}}$ to 338 .

\section{About a third of all observations indicates a fiscal adjustment, as defined} above (Tables 1 and 2). Of these, more than half were examples of a tight fiscal stance. On average, the adjustment came primarily through expenditure cuts. A relatively small percentage of all episodes of fiscal adjustment was successful, with no significant

\footnotetext{
${ }^{28}$ The explicit consideration of fiscal policy volatility, as proxied by $\sigma_{\mathrm{i}}$, tries to account for the possibility that the same amount of fiscal impulse may be extraordinary for a usually-fiscally-disciplined country but rather ordinary for less-disciplined country.
} 
difference between tight and very tight adjustment (Tables 3 and 4). The majority of failed attempts at fiscal consolidation appears to occur when the fiscal stance is tight. In this regard, it is worth noting that, in the case of Canada (1994-97), the UK (1995-99) and the USA (1994-98), prolonged periods of fiscal austerity — that is, periods in which the index of fiscal impulse indicates a tight or very tight fiscal stance - ended with failure. In all cases, only the first three years would qualify as successful according to the definition above.

10. Table 5 confirms the results in the literature. Successful adjustments tend to reduce payroll costs - either through wages or employment or, more likely, both - and welfare payments - usually through a rationalization of benefits and transfer programsrelatively more than unsuccessful consolidations. Also, income tax increases are the main channel to raise revenues.

Table 1. Fiscal Adjustment, Total Expenditure and Revenues

\begin{tabular}{|c|c|c|c|c|c|}
\hline & \multirow{2}{*}{$\begin{array}{c}\text { No. of } \\
\text { episodes }\end{array}$} & \multicolumn{2}{|c|}{ Index of fiscal impulse } & \multirow{2}{*}{$\begin{array}{c}\text { Average } \\
\text { primary } \\
\text { expenditure }\end{array}$} & \multirow{2}{*}{$\begin{array}{l}\text { Average } \\
\text { taxation }\end{array}$} \\
\hline & & Average & $\begin{array}{l}\text { Standard } \\
\text { deviation }\end{array}$ & & \\
\hline Tight & 58 & -1.3 & 0.3 & -0.7 & 0.2 \\
\hline Very tight & 45 & -4.3 & 0.4 & -2.8 & 1.1 \\
\hline All observations & 338 & -0.1 & 2.2 & -0.1 & 0.1 \\
\hline
\end{tabular}

Table 2. Fiscal Adjustment: List of Countries 1/

\begin{tabular}{ll}
\hline & AUS (1993, 1995, 1997, 1999, 2002), AUT (1992, 2000), BEL (1993, 1994, 2000, \\
& 2001), CAN (1994, 1999), DNK (1996, 2000), FIN (1998), FRA (1997), DEU (2000), \\
& GRC (1999, 2000), HUN (2003, 2004), ISL (1992), IRL (1996, 1997, 2004), ITA \\
& (1992), JPN (1997, 2001), KOR (1993, 1995, 1999), LUX (1994), NLD (1991, 1993), \\
& NZL (1993), NOR (1995, 1996, 1999, 2004), POL (1997, 2000, 2002), ESP (2001, \\
& 2002), ESP (2001, 2002), SWE (1995, 2000), CHE (1996), GBR (1991, 1995, 1997, \\
& 1999), USA (1991, 1994-95, 1997, 1998, 2000) \\
& AUS (1996), AUT (1996-97, 2001), BEL (1997-98), CAN (1995-97), CZE (1996, \\
& 2004), DNK (1997, 1999, 2004), FIN (2000), FRA (1996), DEU (1996), GRC (1994), \\
& ISL (1995, 1997, 1999), IRL (2000), ITA (1991, 1995, 1997), JPN (1999), KOR \\
& (2000), LUX (1993, 2000), NLD (1996), NZL (1994, 2000, 2002), NOR (2000), OIK \\
& (2004), PRT (1992, 1995, 2002), SVK (1994), SWE (1996), CHE (1999-2000), GBR \\
& (1998, 1998), USA (1996)
\end{tabular}

$1 /$ In several cases, fiscal adjustment continues over a period of years. For country codes, see http://www.un.org/Depts/unsd/methods/m49alpha.htm. 
Table 3. Fiscal Adjustment: Successes and Failures

\begin{tabular}{llc}
\hline & Tight & Very tight \\
\hline No. of successful adjustments & 11 & 12 \\
in percent of total adjustments & 12 & 13 \\
No. of failed adjustments & 40 & 28 \\
in percent of total adjustments & 44 & 31 \\
Total 1/ & 51 & 40 \\
\hline
\end{tabular}

$1 /$ By construction of the index of success and failure, the total in this table does not include the 12 episodes of fiscal adjustments that occurred in 2002-04, which are included in Table 1.

Table 4. Fiscal Adjustment: List of Successes

Tight AUS (1995), CAN (1994), FIN (1998), KOR (1999), NZL (1993), NOR (1999), SWE (1995), GBR (1995, 1997), USA (1994-1995)

Very tight AUS (1996), AUT (1996), CAN (1995-97), ISL (1995), ITA (1991, 1995), NZL (2000), SWE (1996), CHE (1999), GBR (1996), USA (1996)

1/ In several cases, fiscal adjustment continues over a period of years. For country codes, see http://www.un.org/Depts/unsd/methods/m49alpha.htm.

\section{Fiscal Consolidation in Greece}

11. As of 2004 and in terms of budget expenditure components, Greece's general government wage bill, and benefits and transfers remained somewhat above the average in OECD countries as a share of "old" GDP and current primary expenditure (Figures 1 and 2). ${ }^{29}$ Reflecting the large stock of public debt, interest payments take up a significant share of available resources (Figure 3). Investment expenditure in Greece has been higher than the average over the last few years of the sample, reflecting a drive to improve infrastructure and the preparation for the 2004 Olympic games. Other public expenditure components that set Greece apart vis-à-vis its OECD partners are health and military spending (Figure 4).

\footnotetext{
${ }^{29}$ The level of GDP for 2000-05 was recently revised up by about 26 percent, although growth rates of real GDP were little affected. This chapter uses the pre-revision GDP, in part because historical revisions have not yet been published. These revisions had much less important effects in the government sector.
} 
Table 5. Charactersitics of Successful and Failed Fiscal Adjustments 1/

\begin{tabular}{|c|c|}
\hline No. of successful adjustments & 23 \\
\hline $\begin{array}{l}\text { Expenditure } \\
\text { Wages } \\
\text { Investment } \\
\text { Benefits and transfers } \\
\text { Subsidies } \\
\text { Other expenditure }\end{array}$ & $\begin{array}{l}-0.4 \\
-0.2 \\
-0.4 \\
-0.1 \\
-0.4\end{array}$ \\
\hline $\begin{array}{l}\text { Taxation } \\
\text { Income tax } \\
\text { Wealth and other taxes } \\
\text { Production and imports taxes } \\
\text { Capital tax } \\
\text { Social security contributions }\end{array}$ & $\begin{array}{l}0.4 \\
0.0 \\
0.0 \\
0.0 \\
0.0\end{array}$ \\
\hline $\begin{array}{l}\text { Public employment } \\
\text { Ratio to total employment } \\
\text { Ratio to labor force }\end{array}$ & $\begin{array}{l}-0.3 \\
-0.2\end{array}$ \\
\hline No. of failed adjustments & 68 \\
\hline $\begin{array}{l}\text { Expenditure } \\
\text { Wages } \\
\text { Investment } \\
\text { Benefits and transfers } \\
\text { Subsidies } \\
\text { Other expenditure 2/ }\end{array}$ & $\begin{array}{r}-0.2 \\
-0.2 \\
0.0 \\
-0.1 \\
-1.2\end{array}$ \\
\hline $\begin{array}{l}\text { Taxation } \\
\text { Income tax } \\
\text { Wealth and other taxes } \\
\text { Production and imports taxes } \\
\text { Capital tax } \\
\text { Social security contributions }\end{array}$ & $\begin{array}{r}0.4 \\
0.0 \\
0.1 \\
0.1 \\
-0.1\end{array}$ \\
\hline $\begin{array}{l}\text { Public employment } \\
\text { Ratio to total employment } \\
\text { Ratio to labor force }\end{array}$ & $\begin{array}{r}-0.1 \\
0.0\end{array}$ \\
\hline
\end{tabular}

1/ General government. All variables are in average changes of ratios to GDP.

2/ There are two large drops in this item in 1993 (Slovak Republic) and 1995 (Czech Republic). Dropping these two observation would reduce the average change to -0.6 . 
12. With regard to the revenue side, income and wealth taxes are lower in Greece than the OECD average, both in terms of GDP and as a share of total revenues

(Figures 5 and 6). Taxes on capital had remained at a level substantially higher than the OECD average for several years prior to 2003, although they are not a large source of revenues. By contrast, taxes on production and imports, and social security contributions are higher than the OECD average.

13. Since 2004, the Greek authorities have made deficit reduction their top priority. In the context of the EU excessive deficit procedure, they are committed to lowering the deficit below 3 percent of GDP in 2006. Measures included the reduction in the corporate tax rate, the introduction of a VAT on real estate transactions, restraint of the public sector wage bill, and tighter control on the spending of public enterprises and hospitals. Consolidation, however, has also hinged heavily on increases in unspecified tax and non-tax revenues, some of which were temporary, and in lower infrastructure investment, in part reflecting the end of the Olympics. Overall, the adjustment has come mainly through tax increases, cuts in public investment and lower interest payments (Figure 7). 
Figure 1. Expenditure Components, 1990-2004

(In percent of GDP)

Greece

$\square$ Greece (revised GDP)

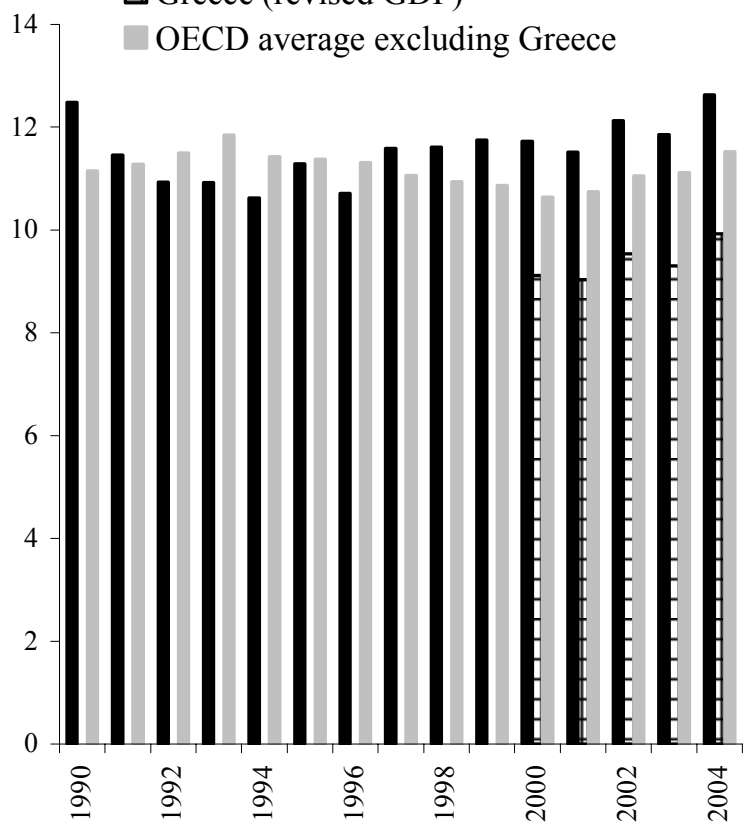

Capital accumulation

\section{Greece}

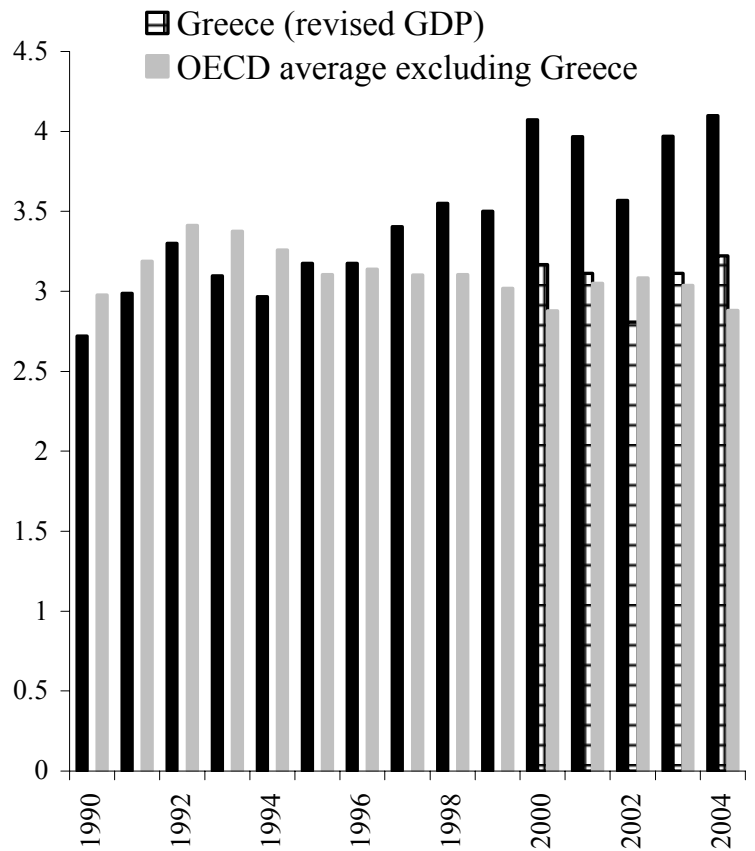

Other primary current expenditure

Greece

日Greece (revised GDP)

$127 \quad$ OECD average excluding Greece

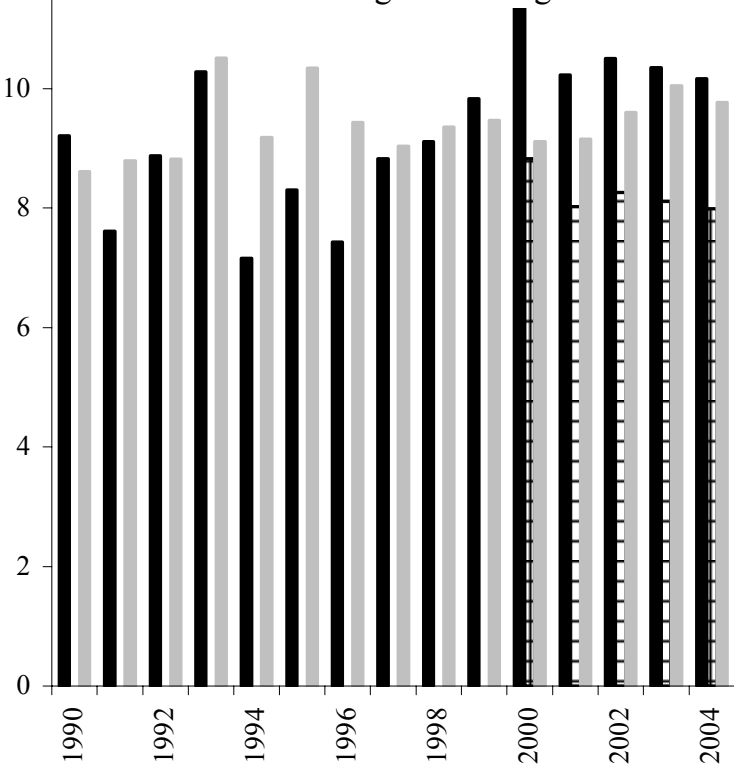

Greece

$\boxplus$ Greece (revised GDP)

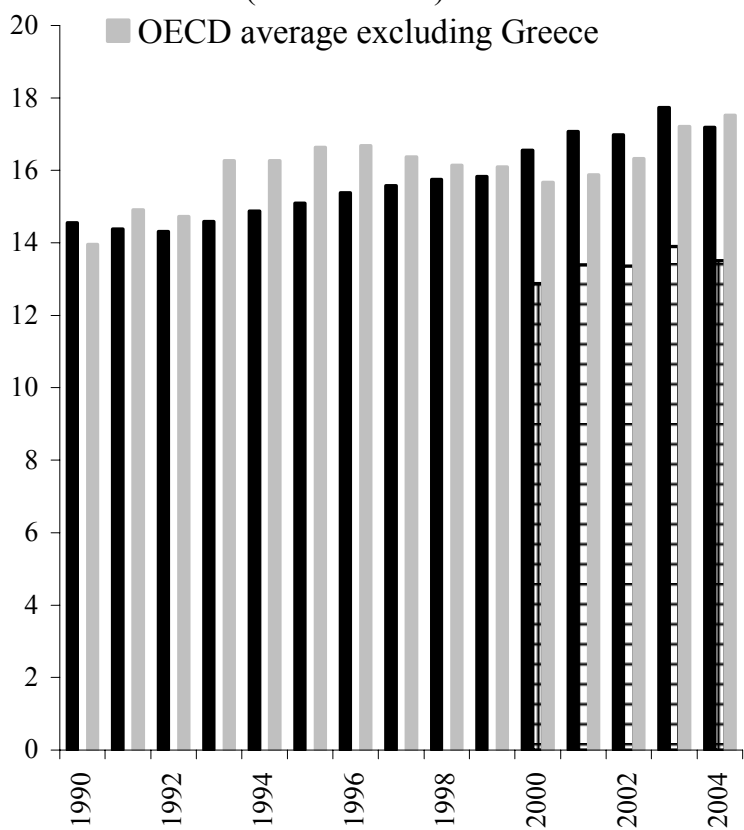

Source: OECD, IMF, and national authorities. Data are for general government. 
Figure 2. Expenditure Components, 1990-2004

(In percent of primary expenditure)

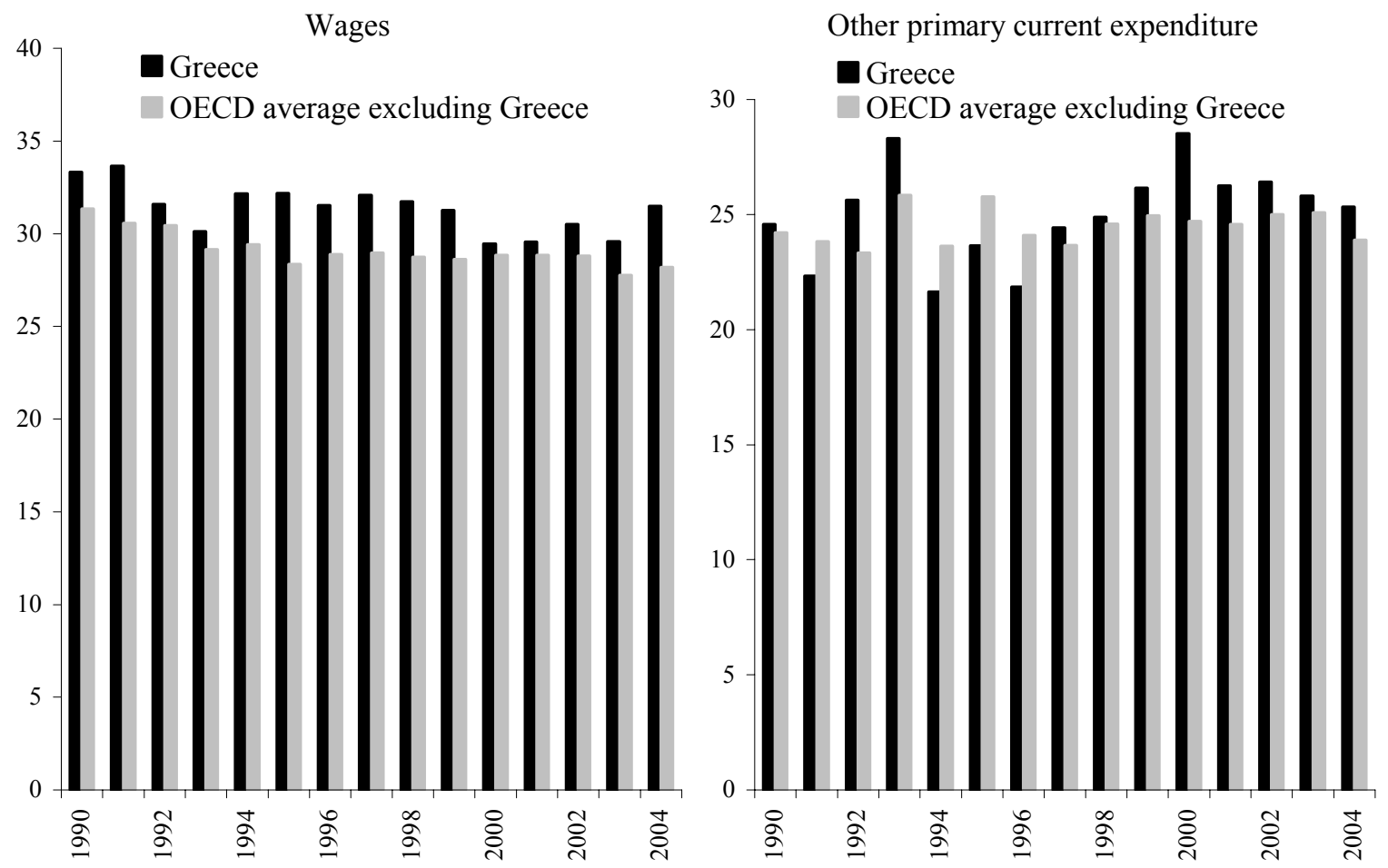

Capital accumulation
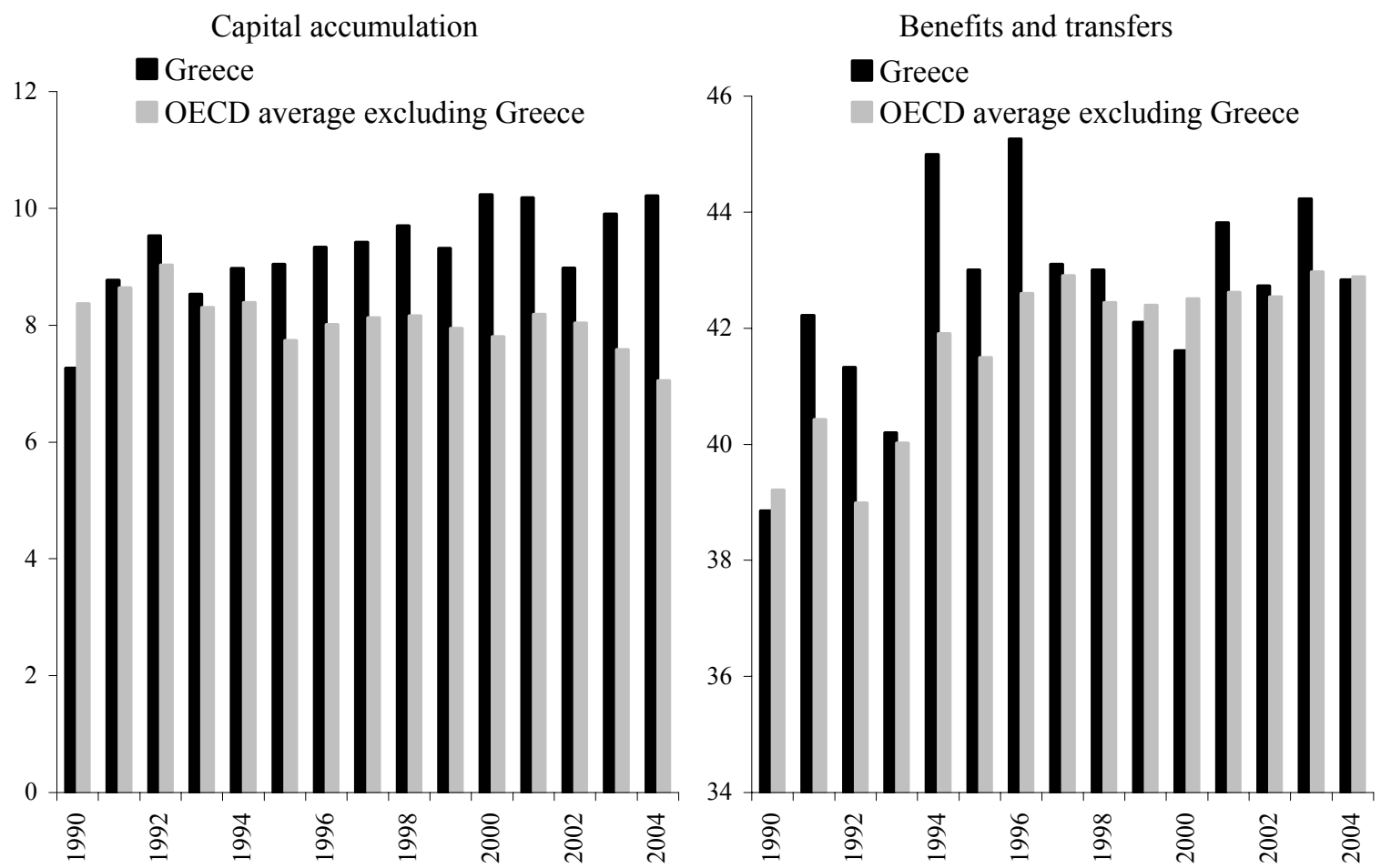

Source: OECD and IMF. Data are for general government. 
Figure 3. Interest Payments, 1990-2004
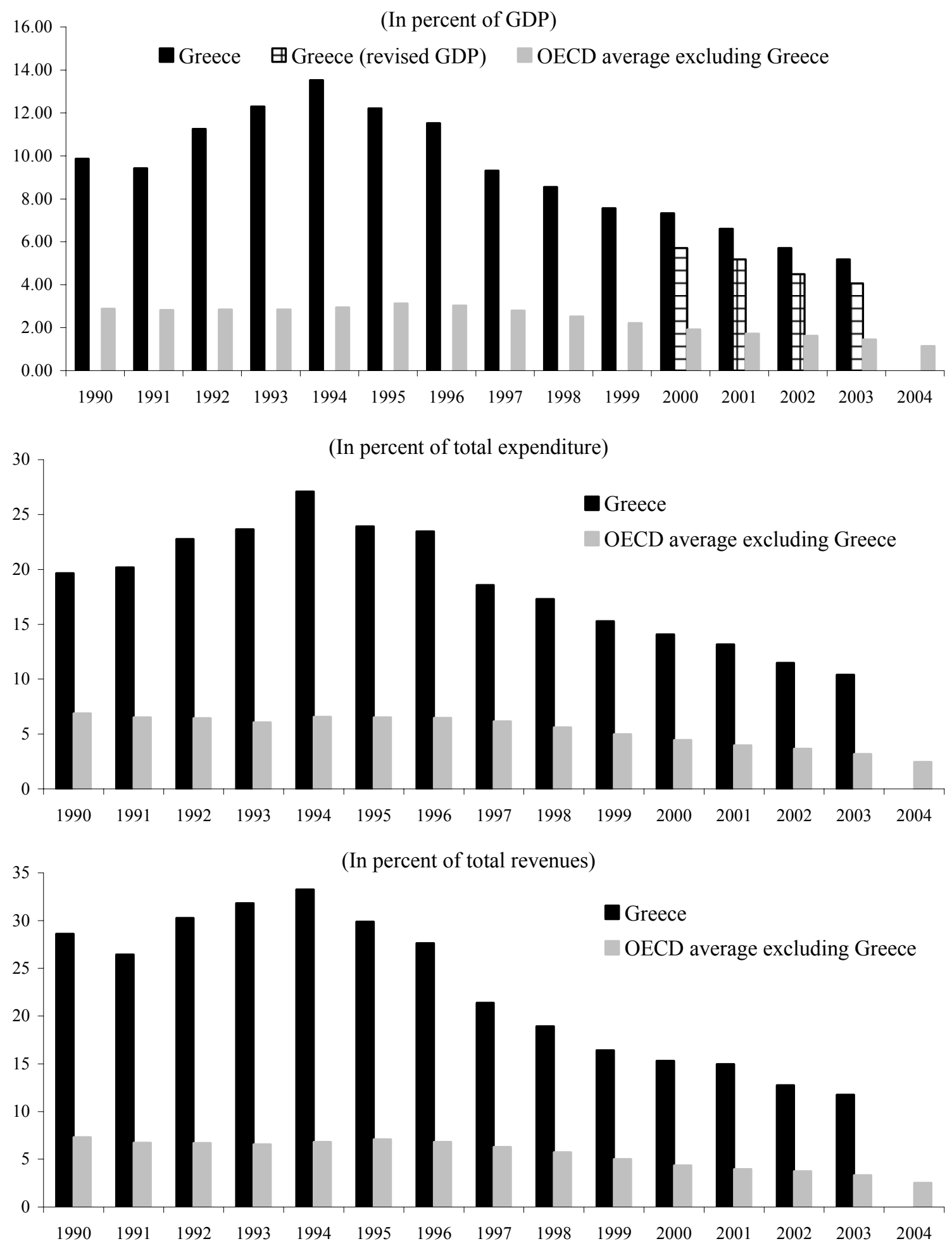

Source: OECD and national authorities. 
Figure 4. Expenditure by Function, 1990-2004

Health

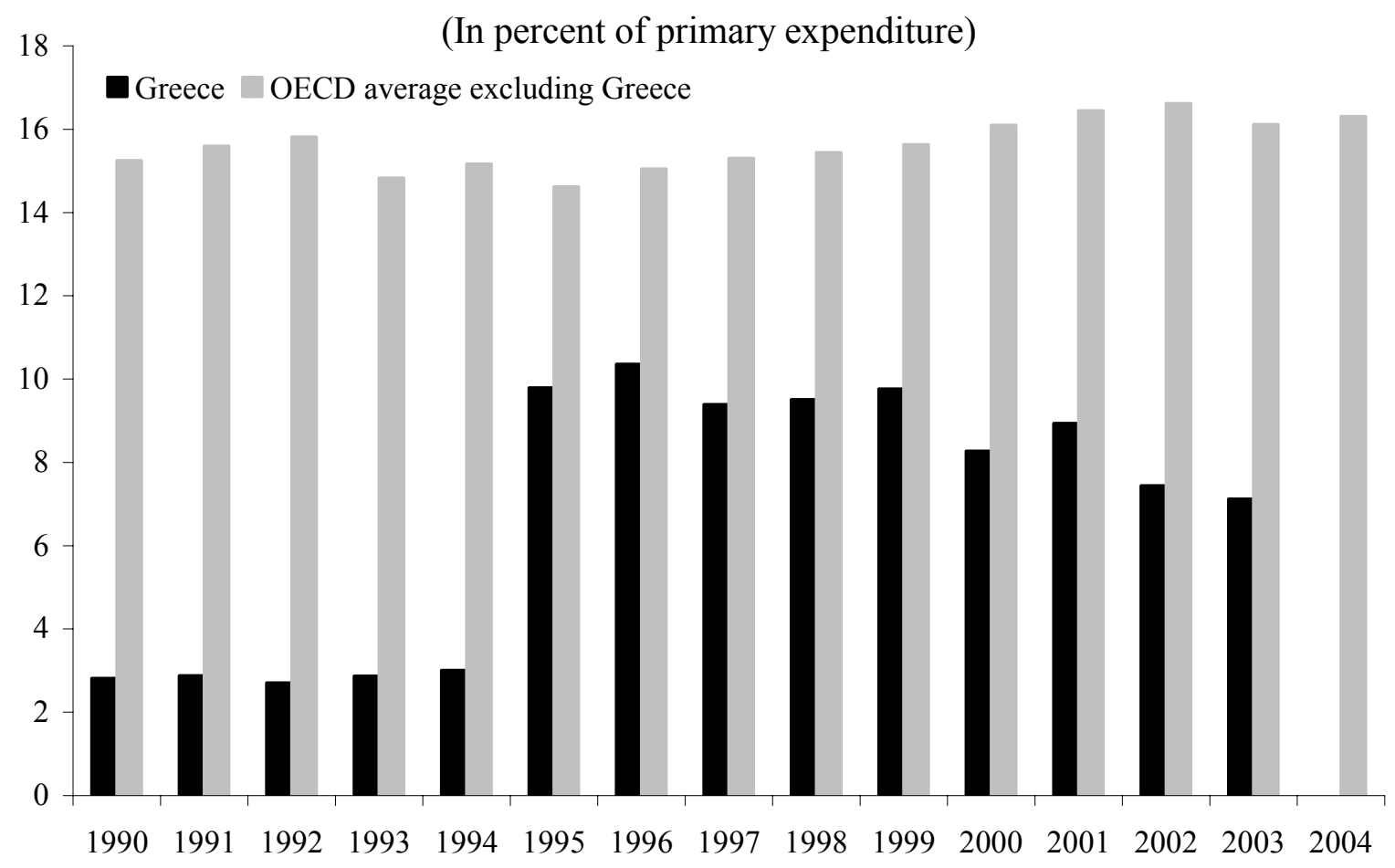

Health

(In percent of GDP)

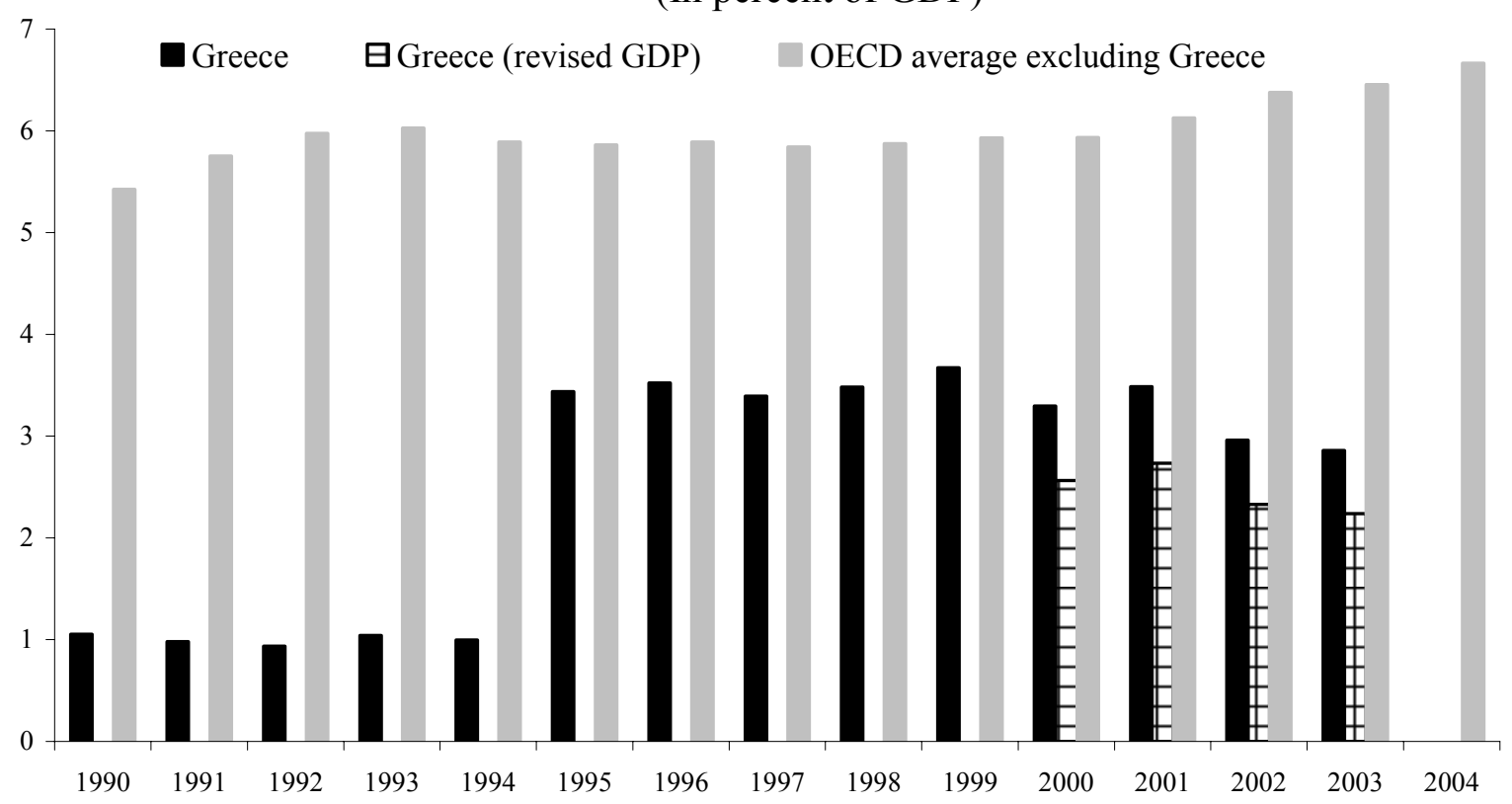

Source: OECD, IMF, and national authorities. Data are for general government. 
Figure 4. Expenditure by Function, 1990-2004 (continued)

Defense

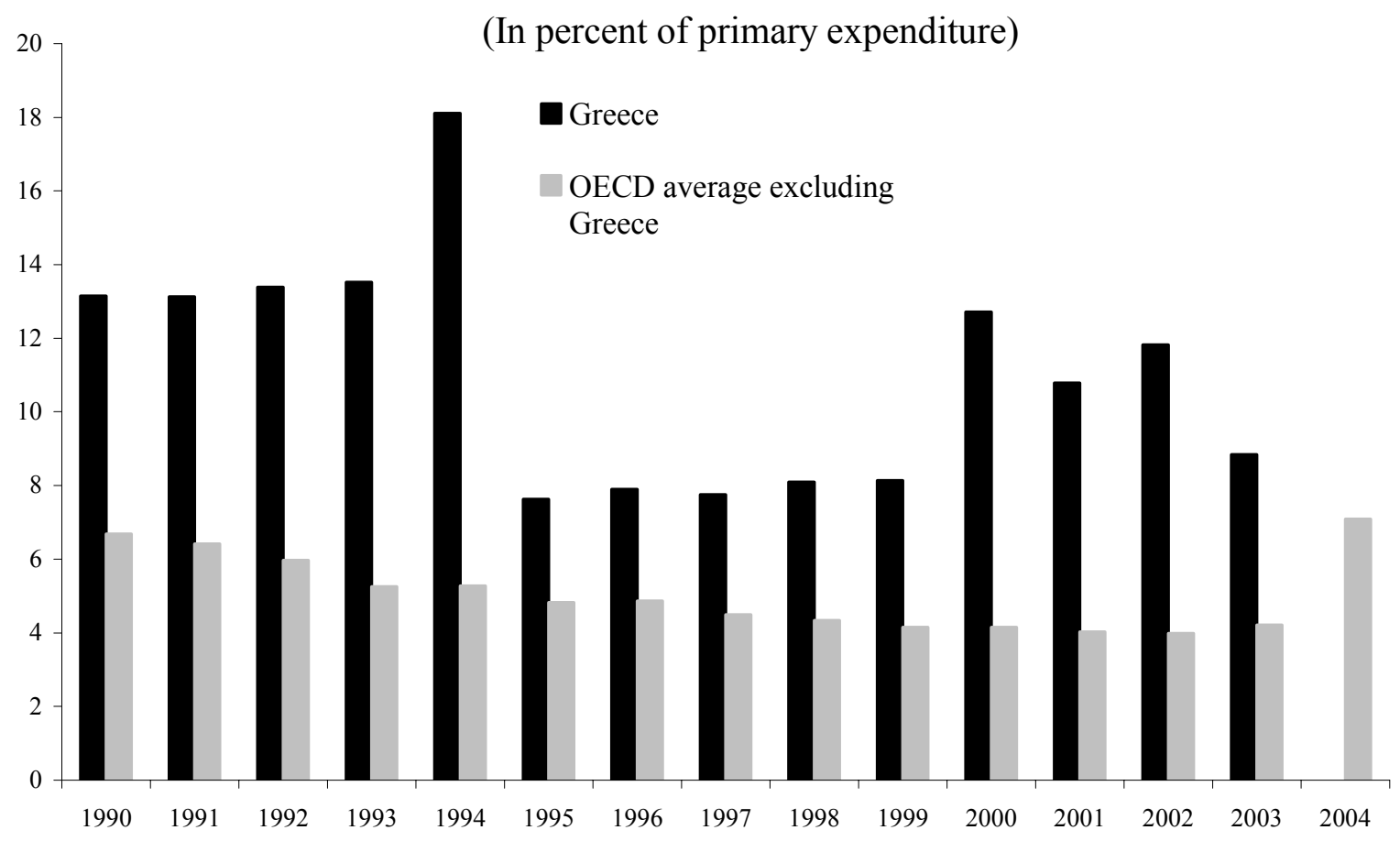

Defence

(In percent of GDP)

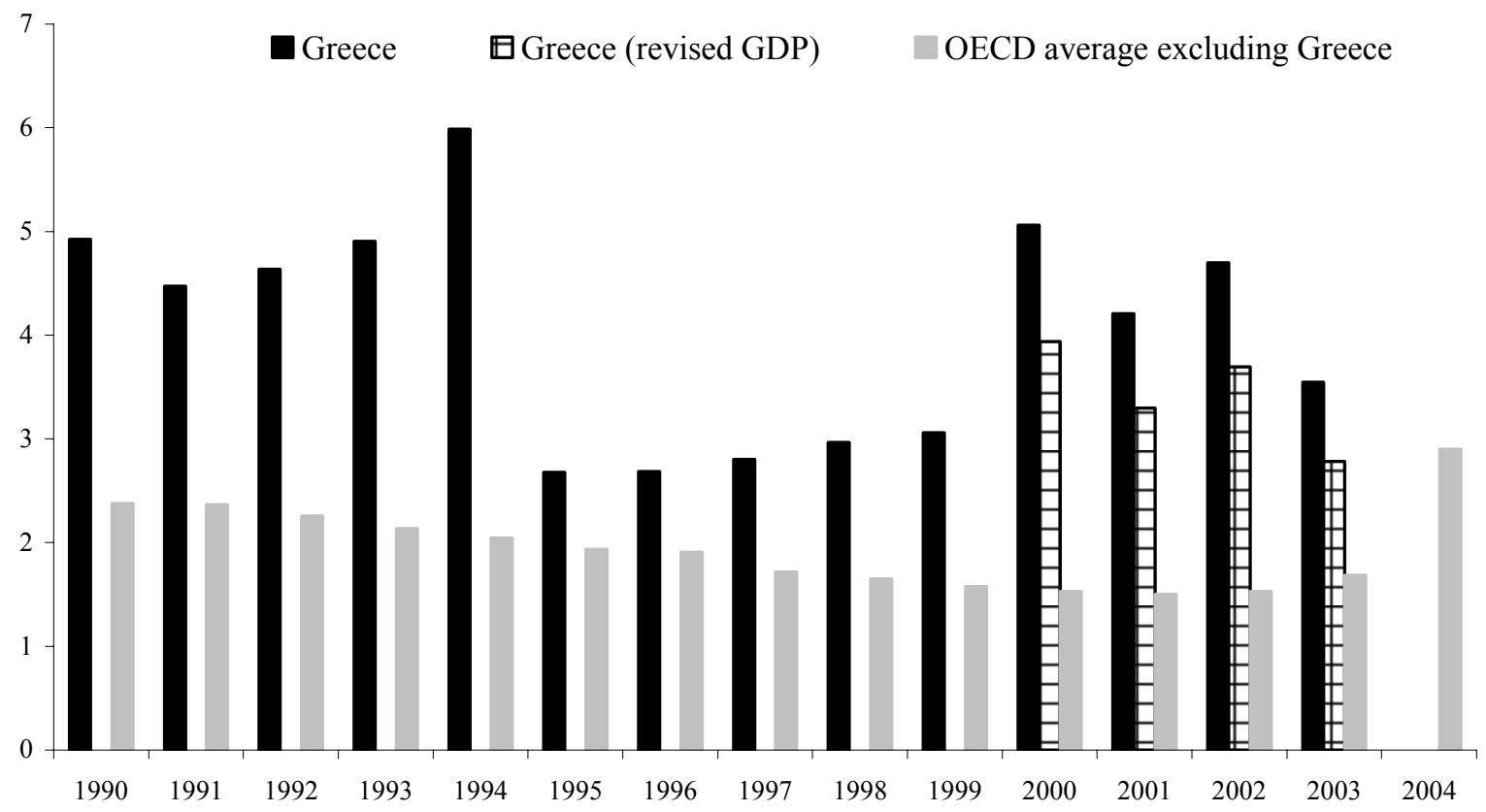

Source: OECD, IMF, and national authorities. Data are for general government. 
Figure 5. Taxation Components, 1990-2004

(In percent of GDP)

\section{Income tax}
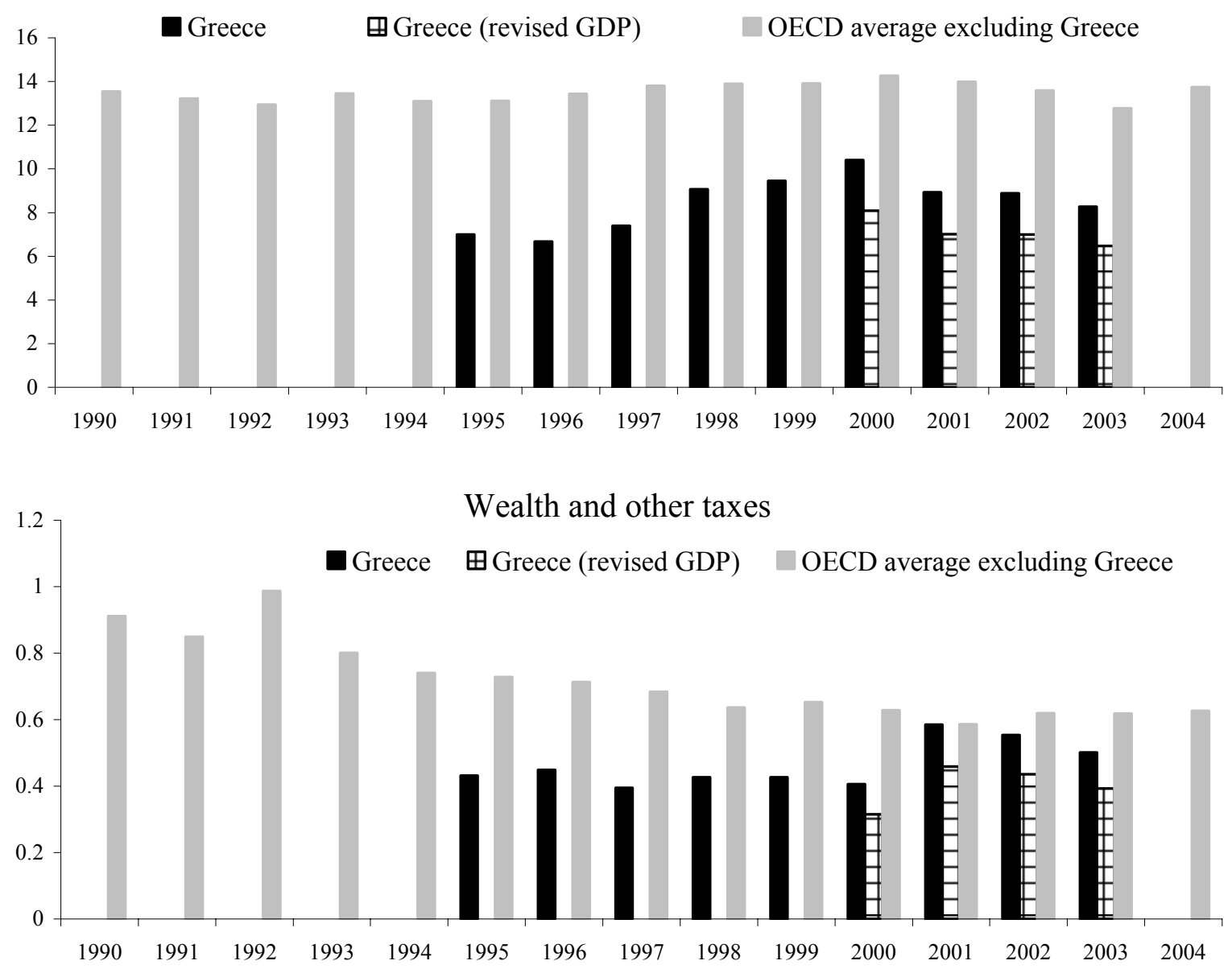

Capital tax

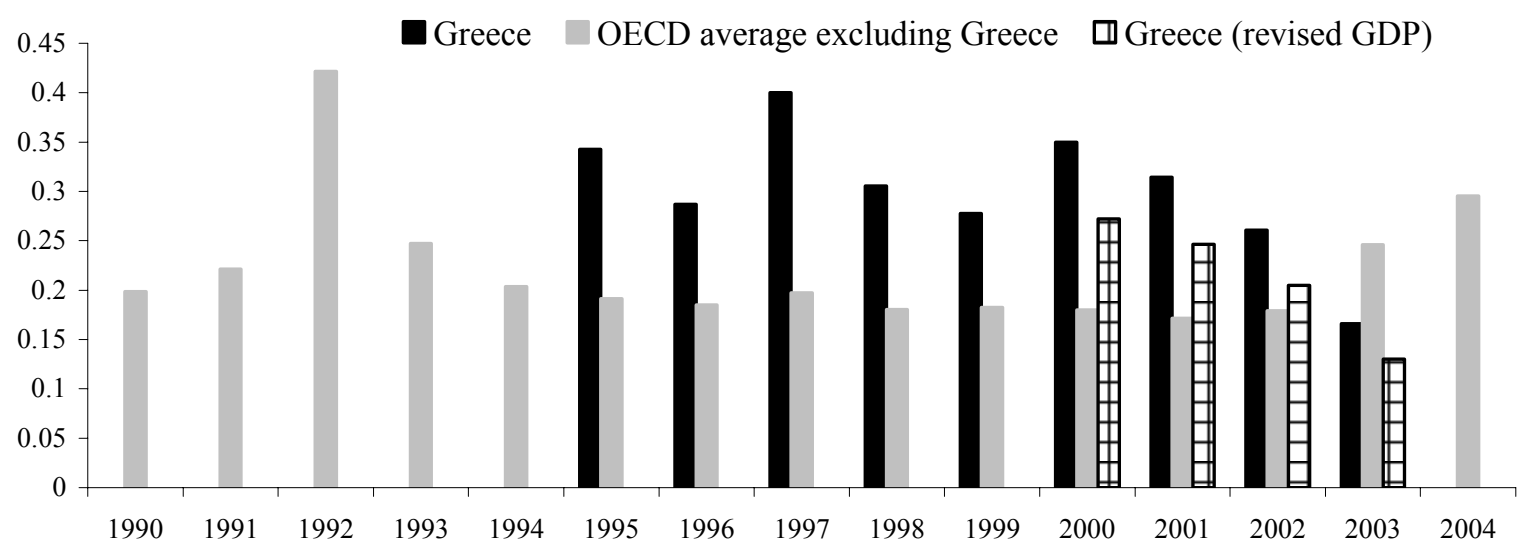

Source: OECD, IMF, and national authorities. Data are for general government. 
Figure 5. Taxation Components, 1990-2004 (continued)

(In percent of GDP)

Production and imports tax



Social security contributions

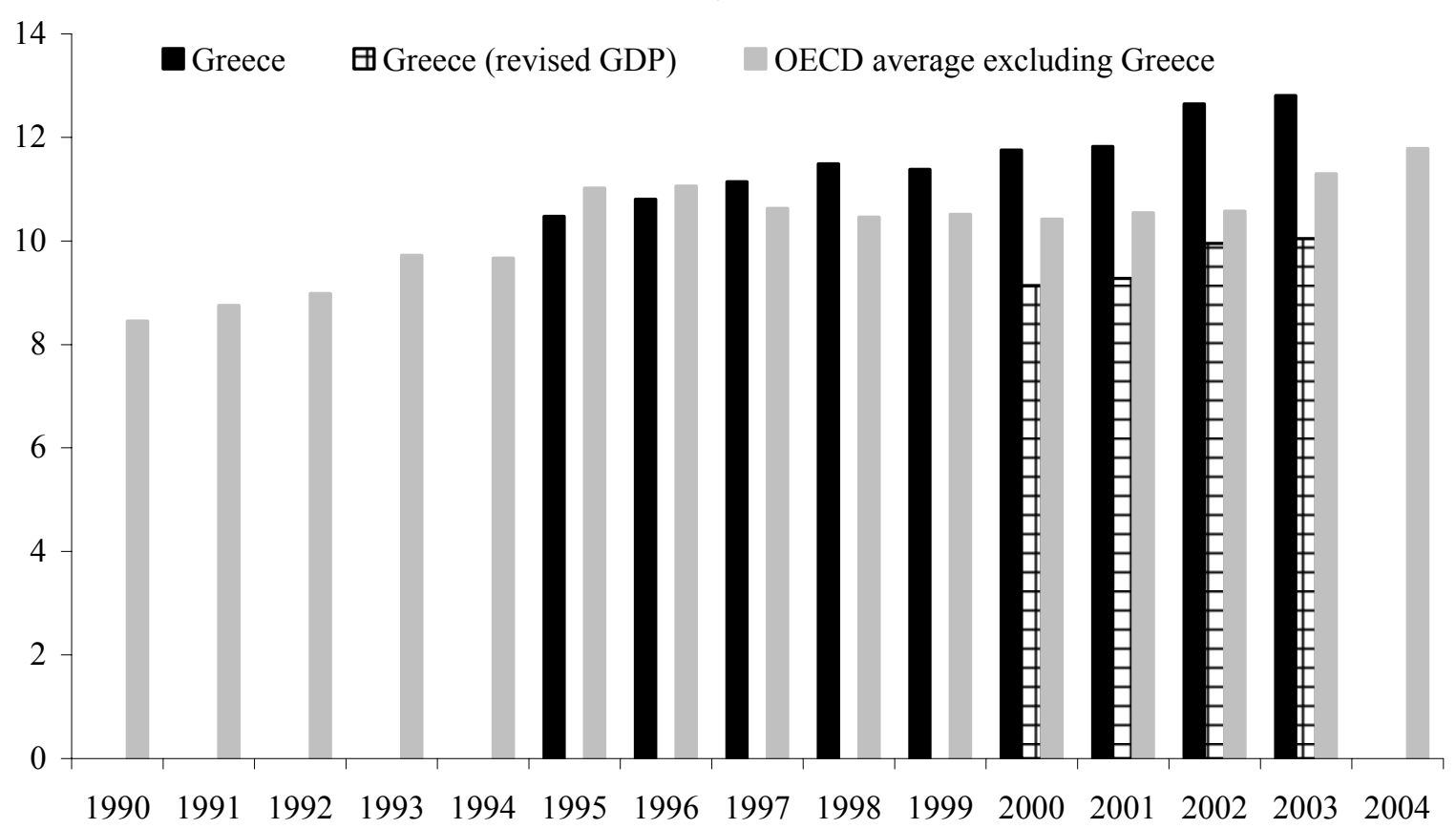

Source: OECD, IMF, and national authorities. Data are for general government. 
Figure 6. Taxation Components, 1990-2004

(In percent of total revenues)

Income tax
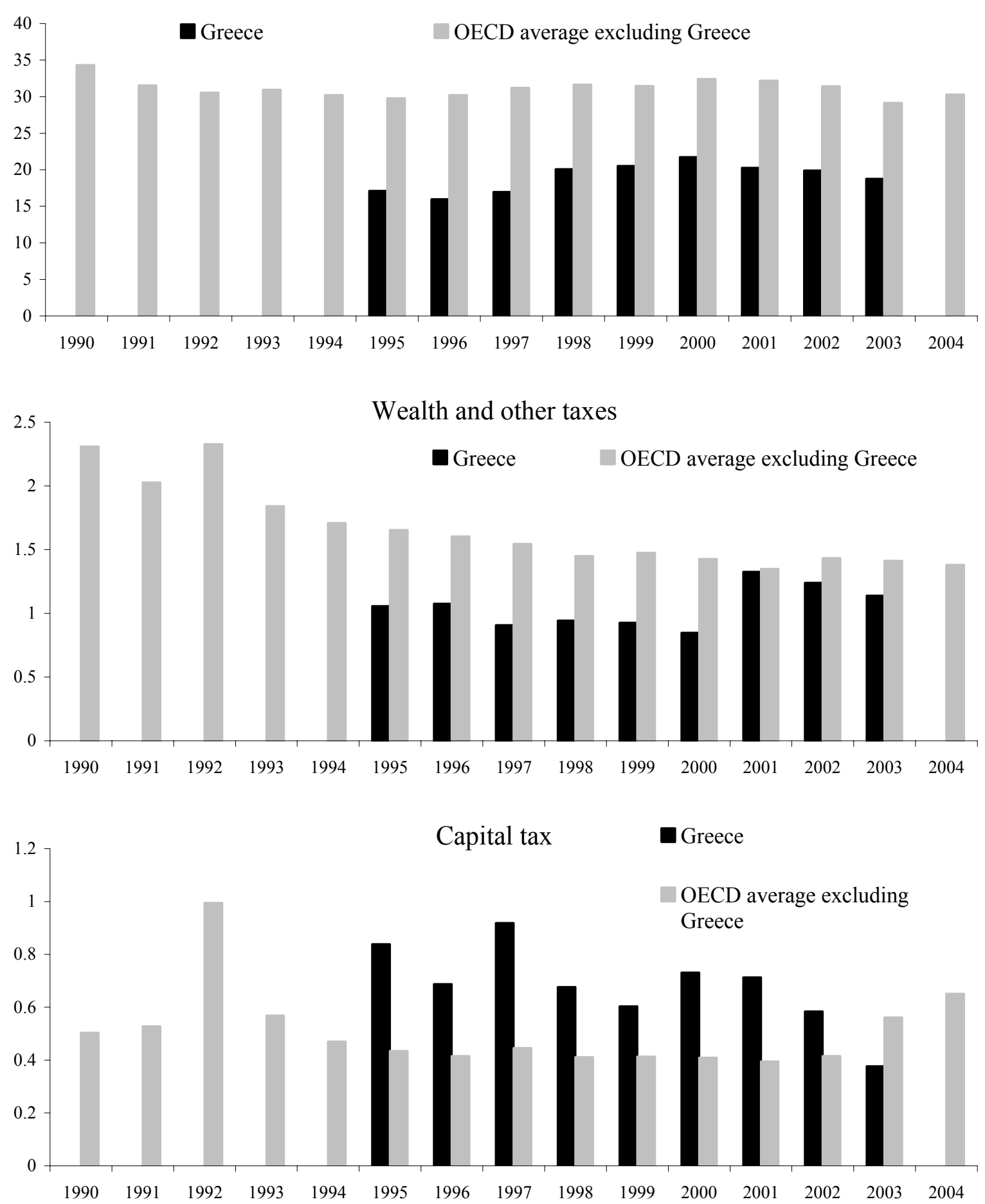

Source: OECD and IMF. Data are for general government 
Figure 6. Taxation Components, 1990-2004 (continued)

(In percent of total revenues)

Production and imports tax
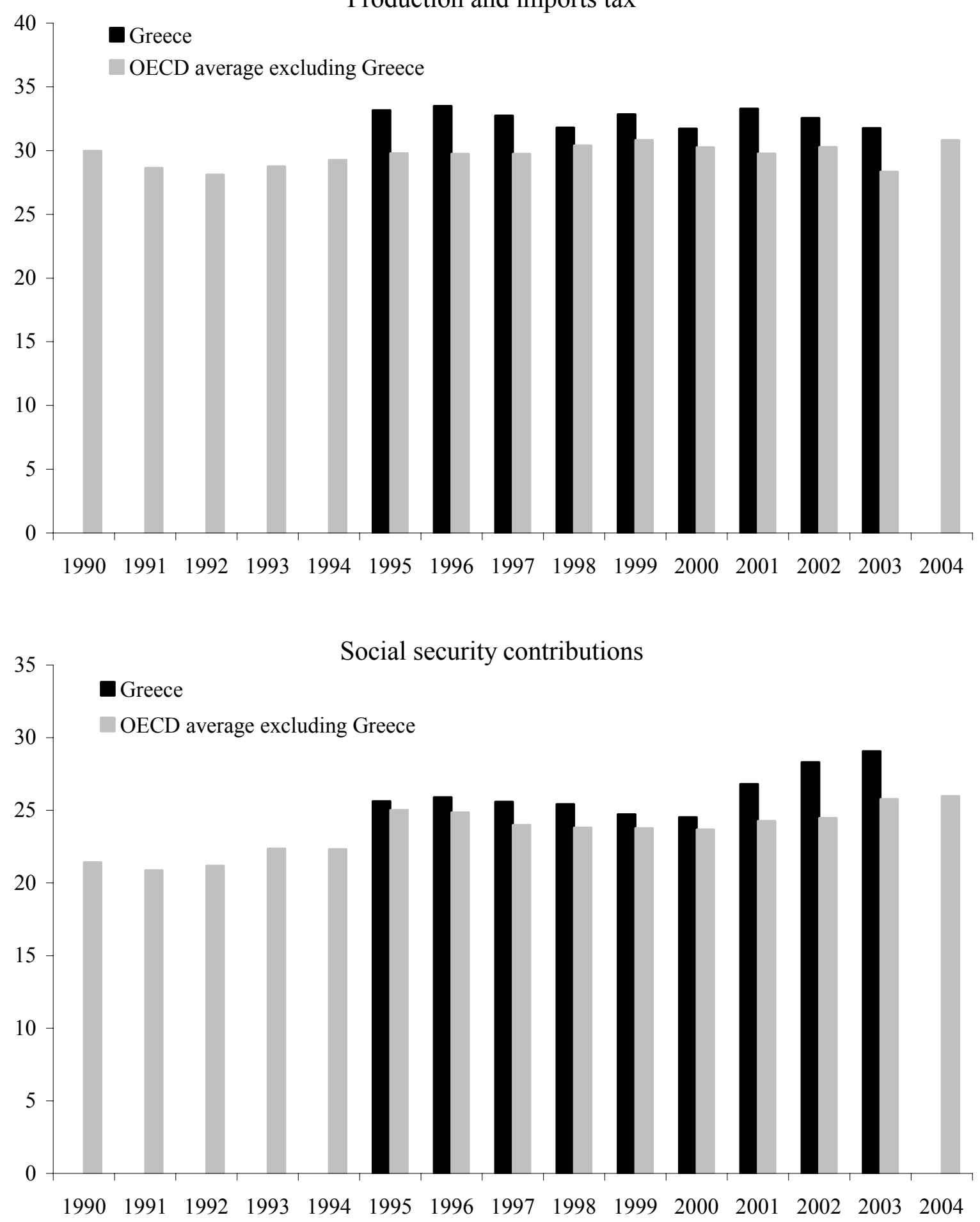

Source: OECD and IMF. Data are for general government 
Figure 7. Greece. Components of Fiscal Adjustment, 2004-06



(Contribution to deficit change)1/

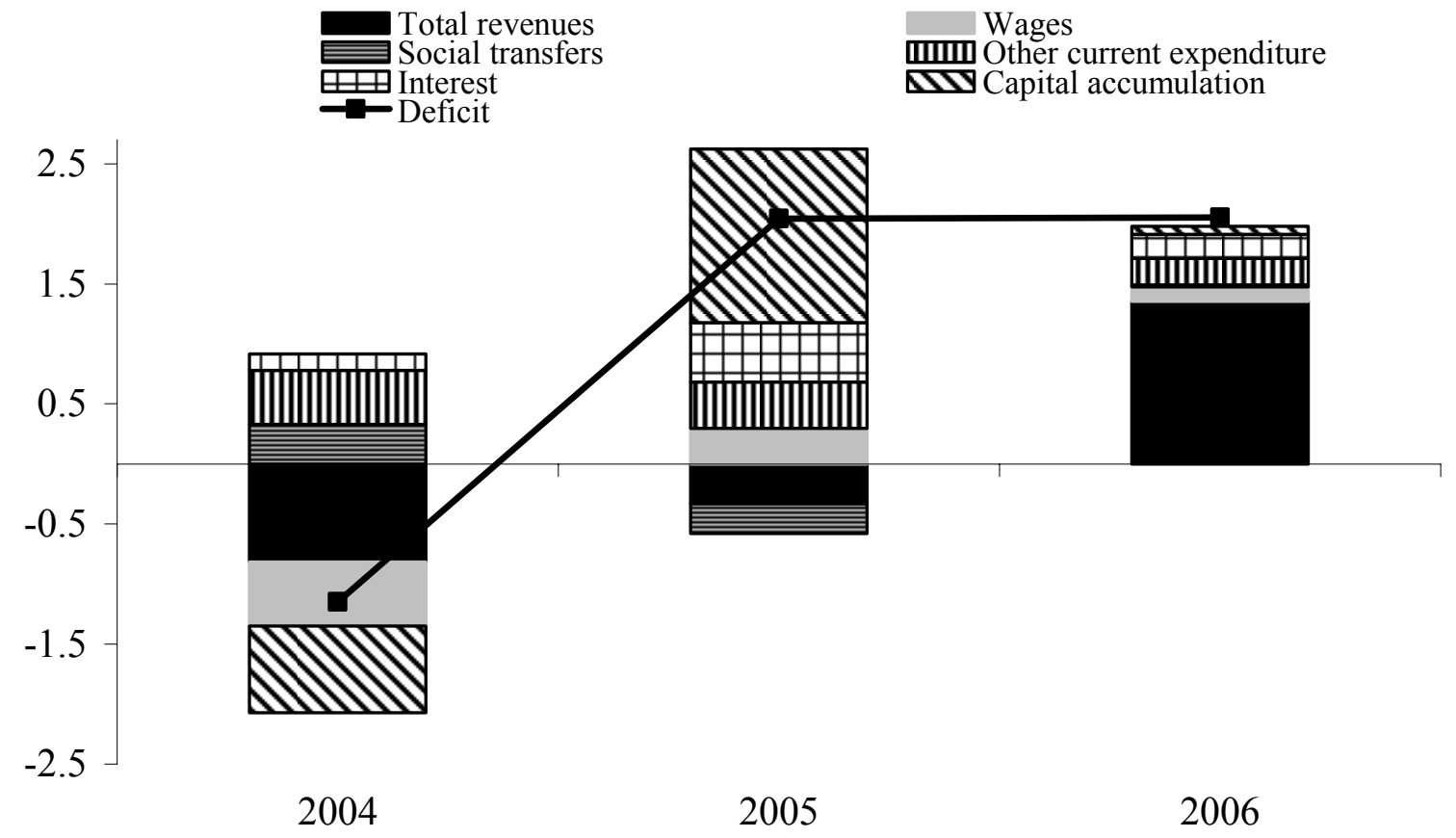

Source: National authorities. Revised GDP.

$1 /$ Change from previous year; in percent of GDP. 


\section{E. Conclusions}

14. International evidence suggests that the composition of the fiscal adjustment is key to its sustainability: quality, not only size, matters when embarking in a fiscal consolidation strategy. In this regard, fiscal consolidation that focuses on control of primary current expenditure, specifically the public sector wage bill, and of benefits and transfers programs appears more likely to be sustainable over time. Moreover, this type of fiscal adjustment is also likely to have an expansionary impact on private consumption in the long run, especially at higher debt-to-GDP ratios. ${ }^{30}$

15. Fiscal consolidation has been the top policy priority in Greece since 2004. The consolidation in 2005 and so far in 2006 has been substantial, with the authorities expected to attain a general government deficit reduction in excess of 5 percentage points, as a share of GDP. Although spending was curbed in many areas when the Olympics ended, the savings came predominantly from cuts in investment projects (about 2 percentage points lower as a share of GDP) and from an exogenous fall in interest payments (about 1 percentage point lower as a share of GDP). At the same time there has been an increase in the tax burden (about 2 percentage points higher as a share of GDP).

16. The quality of the fiscal adjustment in Greece could therefore be improved, as judged against the international experience, notably by shifting decisively toward control of current primary spending. As shown by the international evidence, the public sector wage bill, benefits and transfers programs, and defense are expenditure items whose rationalization could improve the sustainability of the fiscal efforts. In this regard, the already-contemplated reforms to budget processes, and the strengthening of expenditure management and tax administration could play an important role by focusing on strategic planning and prioritization.

\section{Indeed the size of the fiscal consolidation that is needed to bring public finances} to a balance is not that large at about $1 / 2$ percent of GDP a year over the next five years. The quality of the adjustment will, however, be key to build on the progress achieved so far to deliver durable fiscal adjustment and, ultimately, to support continued growth.

\footnotetext{
${ }^{30}$ See Alesina and Perotti (1996) and Afonso, A. (2006). Conceptually, the expansionary impact of fiscal consolidation can be predicated on the basis of demand- and supply-side effects. Among the former, wealth and credibility effects. Among the latter, unit labor costs and labor supply effects.
} 


\section{References}

Afonso, A. (2006) "Expansionary Fiscal Consolidations in Europe: New Evidence”, Working Paper No. 675, September 2006, European Central Bank, Frankfurt.

Alesina, A. and S. Ardagna (1998) "Tales of Fiscal Contractions", Economic Policy, Vol. 10, No. 21 (October), pp. 205-248.

Alesina, A. and R. Perotti (1995) "Fiscal Expansions and Adjustments in OECD Countries", Economic Policy, Vol. 10, No. 21 (October), pp. 205-248.

Alesina, A. and R. Perotti (1996) "Fiscal Adjustments in OECD Countries: Composition and Macroeconomic Effects”, Working Paper No. 96/70, International Monetary Fund, Washington.

Alesina, A., Perotti, R. and J. Tavares (1998) "The Political Economy of Fiscal adjustments", Brookings Papers on Economic Activity, 1, pp. 197-266.

Ardagna S. (1995) "Fiscal Stabilizations: When Do They Work and Why", European Economic Review, 48 (5), pp. 1047-1074.

Blanchard, O. (1993) "Suggestions for a New Set of Fiscal Indicators”, mimeo. 


\section{Credit Growth ANd BANK Vulnerability In The Euro AREA AND Greece ${ }^{31}$}

\section{A. Introduction}

1. Since the mid-1990s, Greece has experienced a sizable increase in private sector credit. Between 1995 and 2005, real private sector credit in Greece rose by an average of $14 \frac{1}{2}$ percent a year, more than any euro-area country except Ireland. This rapid expansion has reflected a variety of factors, including low levels of financial development, pent-up demand pressures following years of credit controls, financial sector deregulation, and low real interest rates.

\section{Although Greece's financial} depth remains below that in the euro area, the rapid credit expansion of recent years has raised concerns about risks. Greece's private sector credit-to-GDP ratio, at 60 percent in 2005 , is the lowest in the euro area, but nonperforming loans (NPLs) are twice as high as in the euro area. ${ }^{32}$ This could indicate that strains may have already risen as a result of the fast credit
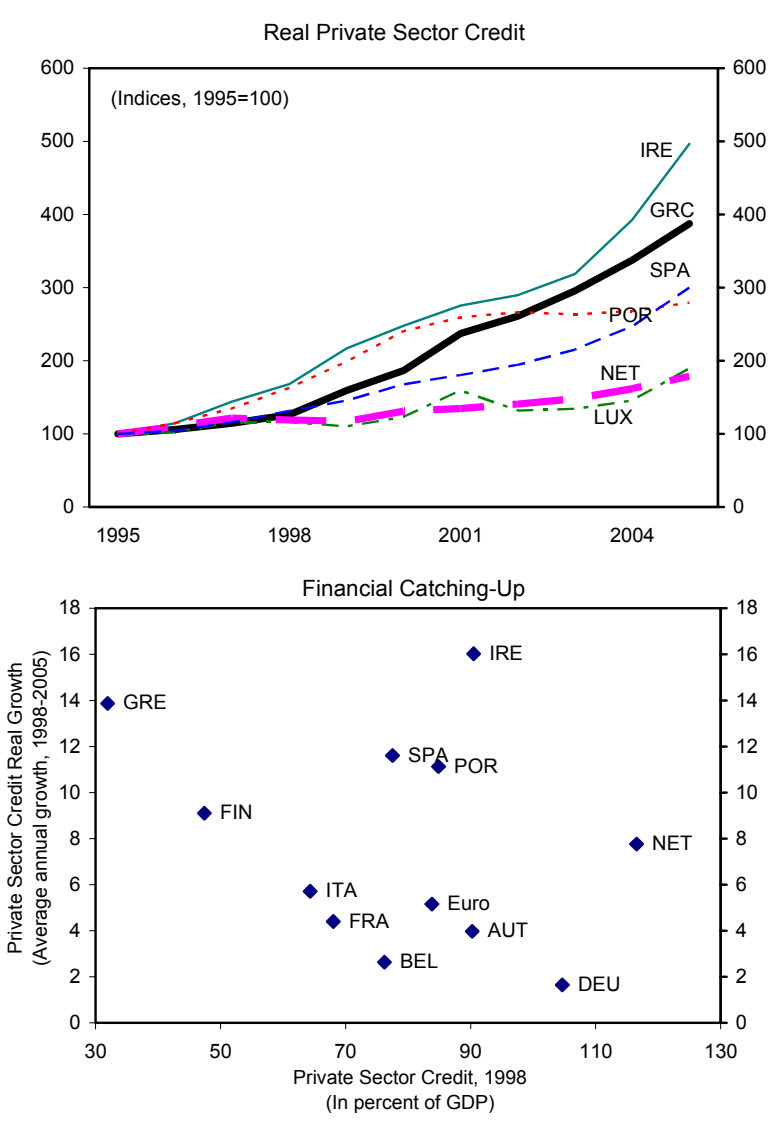
expansion.

3. This chapter analyzes the effect of rising credit growth on the vulnerability of the Greek banking sector in relation to that in the rest of the euro area. A growing body of the literature has found that rapid credit growth is associated with episodes of financial distress. ${ }^{33}$ The argument is that during a lending boom leverage increases and

\footnotetext{
${ }^{31}$ Prepared by Marialuz Moreno-Badia. I thank Nikolaos Stavrianou and Thomas Vlassopoulos for their valuable comments.

${ }^{32}$ The national accounts were revised in September 2006, raising the level of output in 2000-2005 by about 26 percent. Data presented in sections A and B reflect the new GDP. The econometric results are based on the old national accounts, but the conclusions are the same if we use the revised data.

${ }^{33}$ See, for example, Cottarelli, Dell'Ariccia, and Vladkova-Hollar (2005); Goldfajn and Valdés (1997); Demirgüc-Kunt and Detragiache (1997); Kaminsky and Reinhart (1999); and Gourichas et al (2000).
} 
bad projects obtain financing, either because monitoring becomes more difficult, due to the large volume of lending, or because the borrower's higher net worth turns out to be due to an asset price bubble. As exposure increases, the asset quality declines and the banking system becomes increasingly vulnerable. To test this hypothesis, this chapter examines the empirical relationship between credit growth and the vulnerability of banks in the euro area during 1994-2005, and addresses the following issues:

- $\quad$ Are Greek banks more vulnerable to the pace of credit growth than other euro-area banks?

- $\quad$ Does the relationship between credit growth and bank vulnerability change during downturns?

- Are financial risks higher for credit growth rates above certain threshold values?

- What are the main risks factors of the Greek banking system?

4. The main results are as follows:

- In contrast to banks in other euro-area countries, the vulnerability of Greek banks increases with credit booms.

- $\quad$ Credit growth has a larger and more immediate negative effect on Greek banks during real downturns and following an equity market bust.

- $\quad$ The impact of credit growth is more pronounced for those banks in the euro area with faster credit growth. However, Greek banks become more vulnerable at lower credit growth rates than do others in the euro area.

- $\quad$ Greek banks are exposed mainly to credit risks and persistently high NPLs suggest that banks' risk management practices need to improve. In addition, the expansion into southeastern Europe may heighten risks over the medium term as banks start lending to local firms and households whose credit worthiness is less certain.

5. Promoting proper credit assessment and risk management by banks should, therefore, continue to be a policy priority for the authorities, given Greece's rapid credit growth. The BoG has taken a proactive approach but should continue to carefully supervise banks' risk management practices, ensure sufficient provisioning of NPLs, and maintain close cooperation with its counterparts in southeastern Europe.

6. The rest of the paper is organized as follows. Section B describes trends in credit to the private sector in Greece and compares them with those of other euro area countries. Section $\mathrm{C}$ discusses the model specifications and describes the data. Section D presents the empirical results. Finally, Section E analyzes the key risks in the Greek banking system. 


\section{B. The Greek Boom in Context}

7. The lending boom in the Greek banking sector started in the mid-1990s, and since then, Greece has witnessed the most spectacular credit expansion among the euro area countries, after Ireland (Figure 1). In Greece, the credit expansion was not initially related to euro accession since no significant decrease in real interest rates occurred prior to that event (see, for example Brzoza-Brzezina (2005)). However, considerable financial liberalization of household lending took place. In particular, in 1991, commercial banks entered the mortgage market, which has previously been restricted to specialized banks and building societies. In 1993, consumer loans were allowed up to a total amount of $€ 587$, which in 1994 was extended to $€ 23,500$, including credit

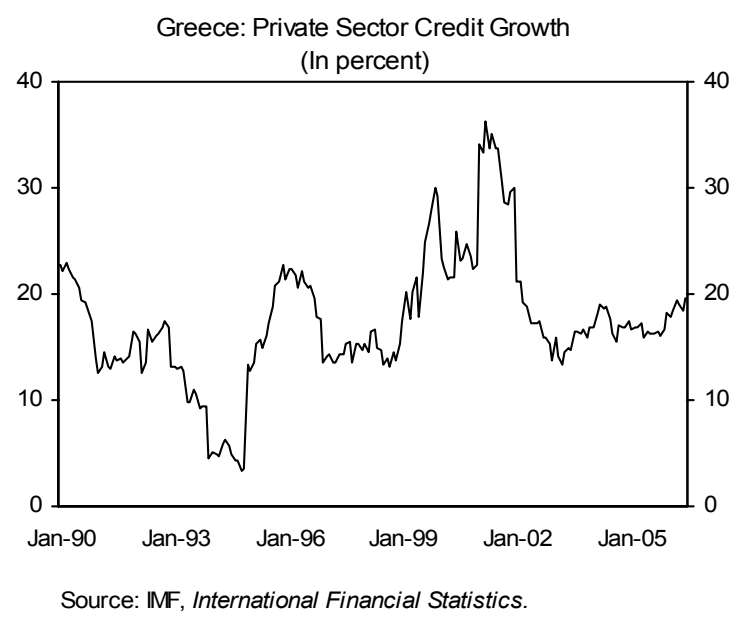
cards, although personal loans (i.e., loans without documents) could not exceed $€ 2,935$ (restrictions that were eliminated in 2003). In addition, foreign exchange controls were removed in 1993-94, resulting in a surge of lending (Honohan, 1999). Upon euro adoption, real rates dropped from $5 \frac{1}{2}$ percent in 1999 to about 1 percent in 2000 and into negative territory the following years. Strong credit growth in the last decade also reflects financial catching-up, given Greece's low levels of financial intermediation compared to other countries in the euro area, and increased competition among financial institutions, both of which were fostered by liberalization.

\section{Initially, credit expansion was driven by both corporate and household}

lending although corporate loans added more because of their higher level (Figure 2). Since 2002, however, corporate credit growth has slowed, partly reflecting a switch to bonds. As a result, the ratio of business credit-to-GDP has remained at about 30 percent of GDP, one of the lowest in the euro area. Meanwhile, household credit has taken a leading role, with very high growth pushing the ratio of household debt to GDP from 14 percent of GDP in 2001 to 29 percent in 2005 (Figure 3). The increase in household debt of recent years has been driven by both mortgage and consumer credit, but, because of its low starting level, mortgage debt is one of the lowest in the euro area. By contrast, consumer credit is one of the highest, thanks 
Figure 1. Private Sector Credit Growth in the Euro Area, 1998-2006 (Annual percent change)
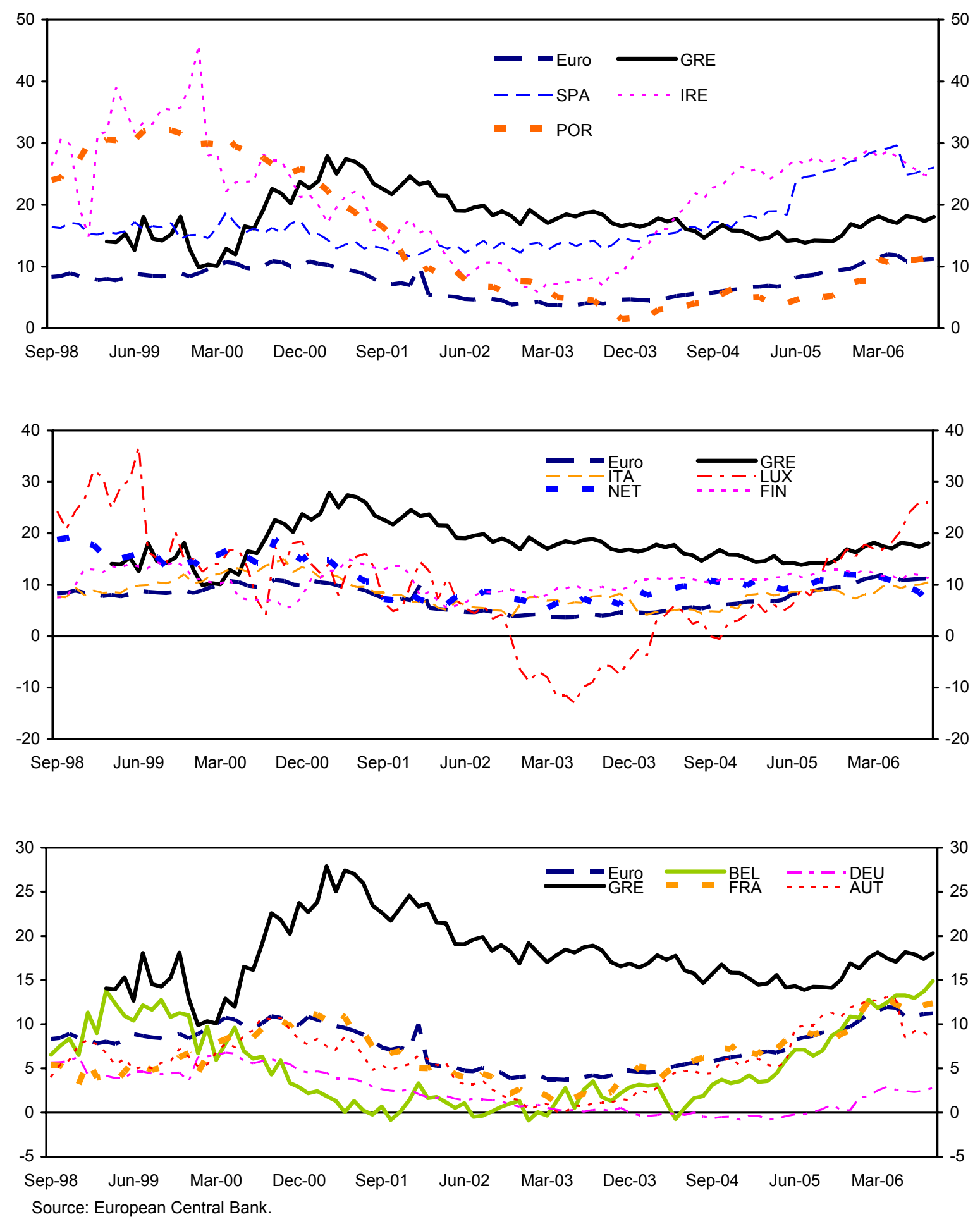
Figure 2. Greece: Private Sector Credit, 1998-2006
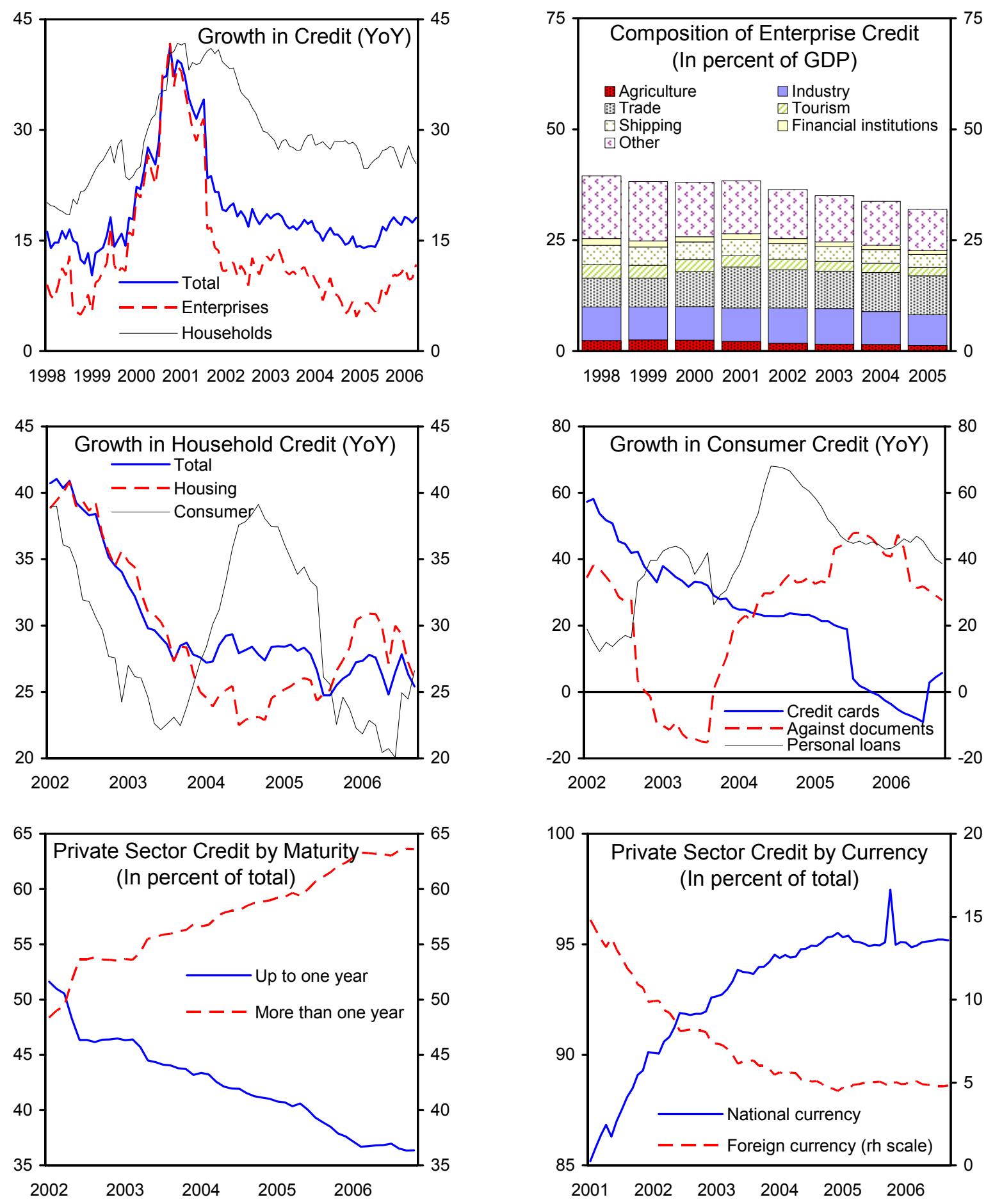

Source: Bank of Greece. 
to the unprecedented growth rates of personal loans and loans against documents. Since 2003, personal loans have increased by an average of 51 percent per year, while loans against documents have increased by 36 percent. Part of this lending has probably substituted for other sources of credit, in particular, credit cards. However, the data may not be fully comparable across countries: lumping consumer and other credit in one category, Greece has one of the lowest levels of this type of credit in the euro area.

\section{Methodology}

\section{Model}

\section{A bank's vulnerability, or alternatively its stability, is measured by their} distance to default (DD), which is increasingly used to assess soundness (De Nicoló and others, 2005; and Maechler, Mitra, and Worrell, 2006) because it is directly related to the probability of a loss exceeding equity capital. It can be summarized as

$$
D D=\frac{k+\mu}{\sigma},
$$

where $k$ is equity capital as percent of assets, $\mu$ is the average return on assets, and $\sigma$ is the standard deviation of returns on assets, a proxy for return volatility. ${ }^{34} D D$ measures the number of standard deviations a return realization has to fall in order to deplete equity under the assumption that returns are normally distributed. Therefore, a higher level of $D D$ implies less vulnerability, or greater stability.

\section{Stability is modeled as a function of credit growth and various} macroeconomic and bank-specific factors. A lagged dependent variable is included to allow for the possible persistence of financial stability. Also, two lags of the credit growth variable are included since it takes time for the vulnerabilities created by a credit boom to surface. ${ }^{35}$ Following Tamirisa and Igan (2006), a parsimonious baseline specification is selected by sequentially testing the significance of various macroeconomic and bankspecific

\footnotetext{
${ }^{34}$ To calculate this indicator, the market value of equity and assets and shareholders' profits should be used. However, due to lack of data, the book values of all variables, derived from balance sheet data, are used instead.

${ }^{35}$ In a recent study, Segoviano Basurto, Goodhart, and Hofman (2006) find that a combination of bank lending and property booms increases the likelihood of financial fragility two to three years after a boom.
} 
Figure 3. Euro Area: Private Sector Credit, 2005 (In percent of GDP)
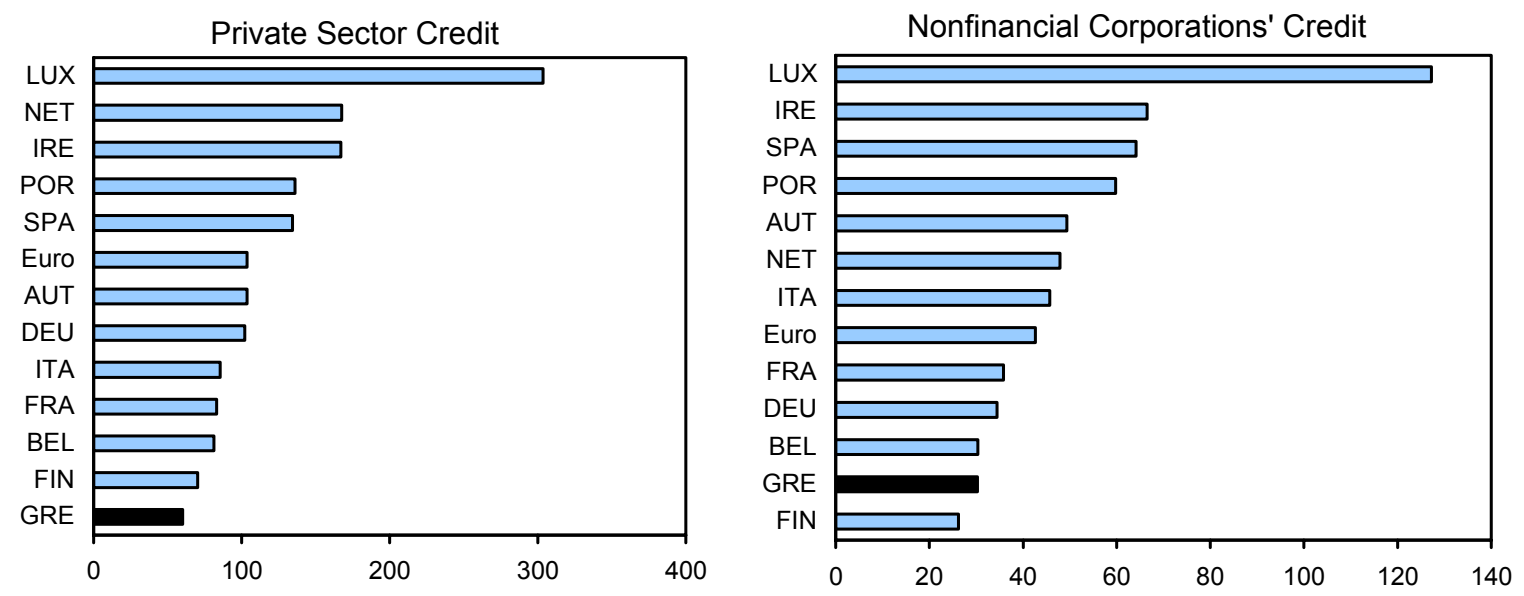

Household Credit
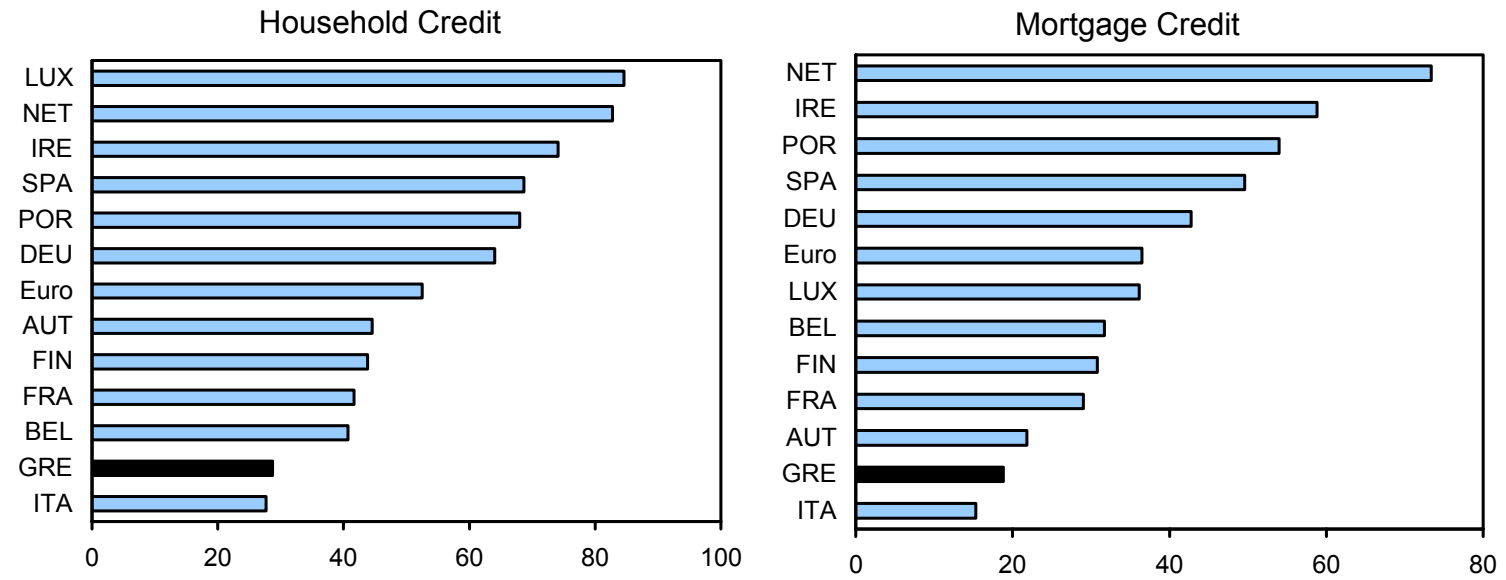

Consumer Credit
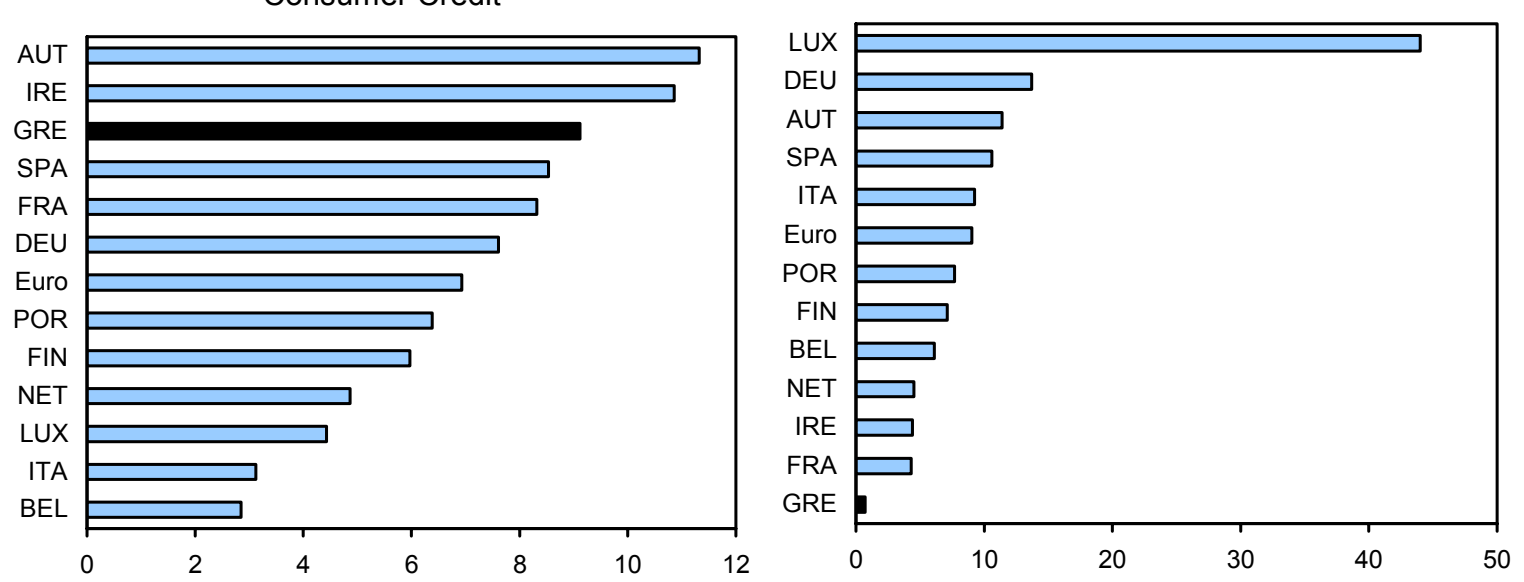

Sources: European Central Bank; IMF, World Economic Outlook; and staff's calculations. 
variables identified in the recent literature as determinants of bank soundness. ${ }^{36}$ The parsimonious baseline specification is

$$
\begin{aligned}
& F_{i, t}=\alpha_{i}+\delta_{t}+\beta_{1} F_{i, t-1}+\beta_{2} \text { Credit }_{i, t-1}+\beta_{3} \text { Credit }_{i, t-2}+\beta_{4} \text { Credit }_{i, t-1} * d_{G R C} \\
& +\beta_{5} \text { Credit }_{i, t-2} * d_{G R C}+\beta_{6} \text { Macro }_{j t-1}+\beta_{7} \text { Bank }_{i, t-1}+u_{i}+\varepsilon_{i, t},
\end{aligned}
$$

where $i$ indexes banks, $j$ indexes countries, and $t$ indexes years. $F S_{i, t}$ is the indicator of stability (i.e. the $D D$ for each bank at each observed point); Credit is the real credit growth; Macro is a set of macroeconomic variables (real GDP growth and GDP per capita); Bank is a set of bank-specific variables (cost-to-income ratio and bank size); $u_{i}$ are firm-specific fixed effects; and $\varepsilon_{i t}$ is a serially uncorrelated error term. As discussed above, the effect of credit growth is expected to change over time. In the short term, credit growth could have a positive effect on financial stability if new loans are highly profitable and risks take time to materialize. Over time, however, loan growth, if not properly managed, may increase credit risks. Positive macroeconomic conditions (measured by higher real GDP growth) and higher level of economic development (real GDP per capita), greater bank efficiency (lower cost-toincome ratio), and larger bank size should also increase stability.

\section{Equation (2) is estimated with the generalized method of moments (GMM)}

difference estimator. The fixed-effects estimator explicitly controls for bank-specific effects. However, even though the within transformation eliminates the $u_{i} \mathrm{~s}$, by construction the transformed error term $\left(\varepsilon_{i, t}-\frac{1}{T} \sum_{t=1}^{T} \varepsilon_{i, t}\right)$ is still correlated with the lagged dependent variable. The bias (which influences all variables) is a function of $T$, and as only $T$ tends to infinity the within estimator of $\beta$ becomes consistent. In addition, some regressors are endogenous. In particular, credit growth is subject to two-way causality, as banks' financial stability supports loan growth, and loan growth, in turn, may create vulnerability. ${ }^{37}$ To solve these issues, a GMM-difference estimator developed by Arellano and Bond (1991) is used. This estimator takes the first difference of each variable to eliminate the bank-specific effects and then uses lagged levels of the variables as instruments. Consistency depends on the

\footnotetext{
${ }^{36}$ The original set of macroeconomic variables considered was (i) GDP per capita; (ii) real GDP growth; (iii) real interest rates; (iv) real exchange rate depreciation; (v) credit-to-GDP ratio; (vi) real house price inflation; and (vii) unemployment. For the bank-specific variables, measures of bank profitability, liquidity, efficiency, and risk (proxied by the net interest margin, liquidity ratio, cost-to-income ratio, loan-to-deposit ratio, and ratio of loan loss reserves to gross loans) were used.

${ }^{37}$ Although credit growth is lagged in the baseline specification, the Sargan test of overidentifying restrictions suggests that this variable is not exogeous.
} 
assumption of no serial correlation in $\varepsilon_{i, t}$ and the validity of instruments. ${ }^{38}$ Two tests suggested by Arellano and Bond (1991) are used to check the validity of our assumptions. The first test looks at whether the error term is second-order serially correlated. The second test is a Sargan test of overidentifying restrictions, where the null hypothesis is that the instruments are uncorrelated with the residuals. Failure to reject the null hypothesis of both tests would support the assumptions.

\section{Data}

\section{Bank-specific data come from the Bankscope database and cover the period} 1990-2005, which after accounting for the lagged variables, leaves an estimation period of 1994-2005. All commercial banks located in the euro area for which data for the period were available are included. ${ }^{39}$ This yielded a total of 1,009 banks, with about six observations per bank on average, although coverage for Greece is more limited, with only about five observations per bank, and there are no observations for 2005 because of a change of accounting standards (Table 1). The number of banks is substantially lower at the beginning of the period, largely because Bankscope is a relatively new data set with improving coverage over time. Macroeconomic data on real GDP and GDP per capita were taken from the IMF's World Economic Outlook. House prices data come from the BIS with the exception of Austria, Portugal and Greece, which come from national sources. Table 2 presents summary statistics of the variables used in the econometric analysis. As with most empirical work at the level of disaggregation of this chapter, results should be interpreted with caution in light of issues related to data quality and consistency. Concerns relate partly to comparability of the data (different accounting standards, for example) and to potential biases related to the entry and exit of banks in the sample.

\section{Mean values of distance to default seem to indicate that the Greek banking system became more vulnerable after the introduction of the euro (Figure 4).} Although vulnerability rose in the euro area as well, probably as a result of the global slowdown, the increase was not as pronounced as in Greece. Nevertheless, Greek banks have since recovered some of their lost ground. Incidentally, Greece's bank-by- bank credit growth took off dramatically following the recovery from the 2000 slowdown, aided by easing global liquidity and low interest rates, and remained above the euro area average. Bank efficiency, measured by the cost-to-income ratio, seems to be comparable to the euro area average, but bank size is larger. Finally, real GDP growth has been stronger than in the euro area; this reflects the catch-up of the Greek economy, as GDP per capita is still below the euro area average.

\footnotetext{
${ }^{38}$ If $\varepsilon_{i, t}$ is not serially correlated, there should be evidence of significant first-order correlation in difference residuals $\left(\varepsilon_{i, t}-\frac{1}{T} \sum_{t=1}^{T} \varepsilon_{i, t}\right)$, but no evidence of second-order correlation in the differenced residuals.

${ }^{39}$ For a detailed description of the data set and definitions, see Appendix I.
} 
Figure 4 . Greece and the Euro Area: Mean Values by Year 1/
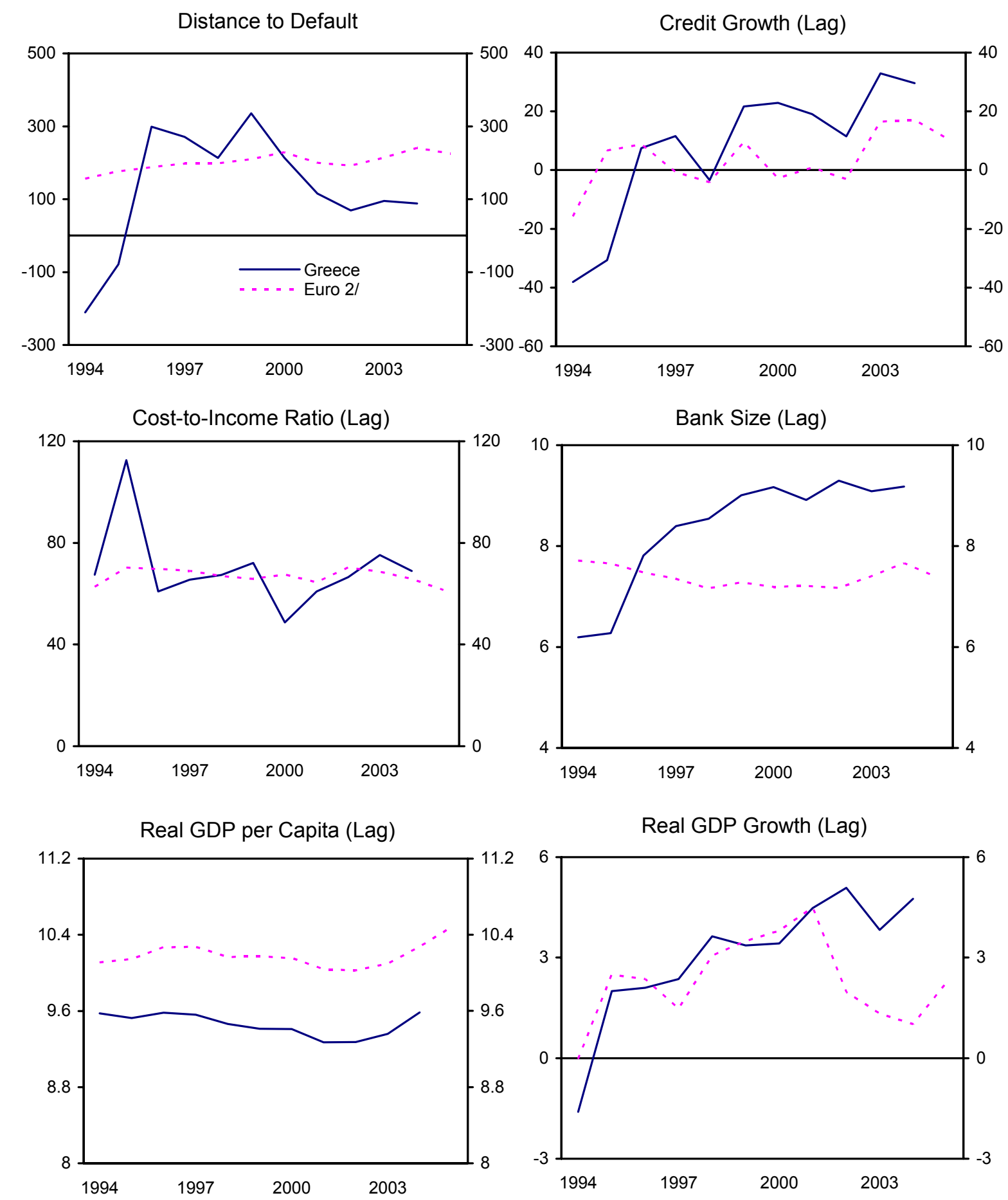

Sources: Bankscope; IMF, World Economic Outlook; and staff estimates.

$1 /$ Legend applies to all figures. For the definition of variables, see Appendix I.

2/ Excluding Greece. 
14. There is a significant dispersion in the $D D$ and credit growth at the bank level. The distribution of $D D$ is asymmetric and skewed toward positive values (Figure 5).

Although, the distribution of credit growth values is more symmetric, it also has fat tails, reflecting rapid credit expansion. The data also suggest little relationship between $D D$ and credit growth for euro area banks. However, there seems to be a positive, though weak, relationship between $D D$ and the first lag of credit growth of Greek banks (Figure 6).

Figure 5. Histograms for Distance to Default and Bank Credit Growth, 1994-2005

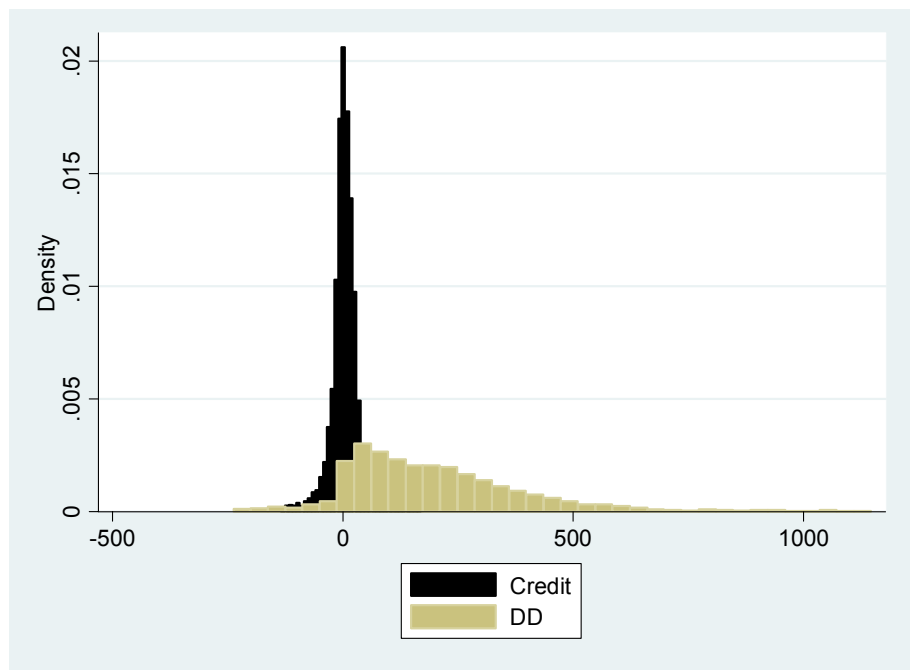

Figure 6. Correlation between Distance to Default and Bank Credit, 1994-2005
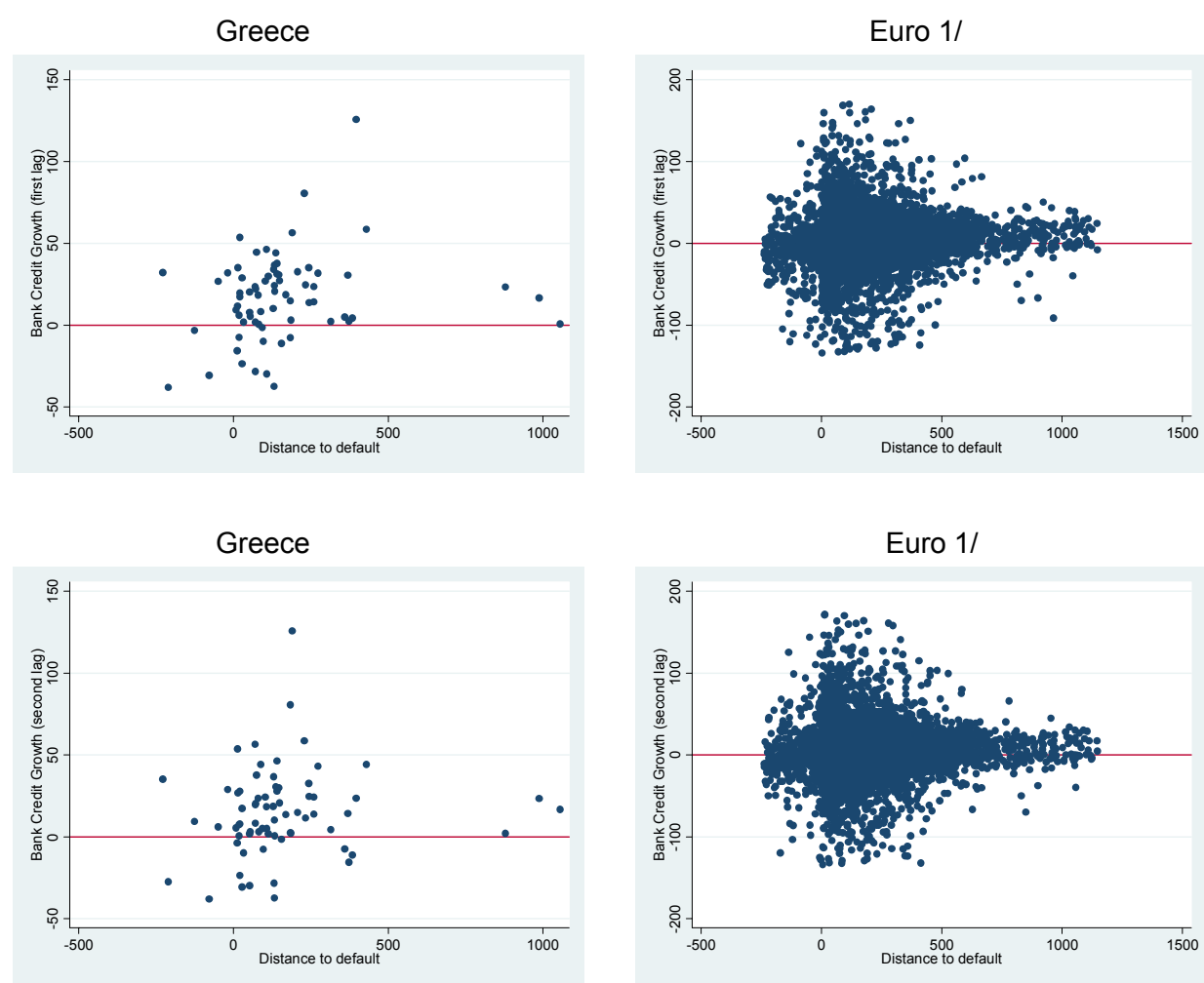

Sources: Bankscope; and staff's calculations. 1/ Excluding Greece. 


\section{Econometric Results}

\section{Baseline specification}

15. Table 3 reports the estimation results of the dynamic financial stability model described in equation (2), focusing on one-stage robust estimates that have been corrected for heteroscedasticity, using a maximum of two lags of each of the explanatory variables as instruments. ${ }^{40}$ For all regressions, there is no sign of second-order serial correlation of the first-differenced residuals, and the Sargan test accepts the null hypothesis that the overidentifying restrictions are valid. The only exception is the baseline specification estimated for the period 1999-2005, where the null hypothesis of no overidentifying restrictions is rejected and the estimator is therefore inconsistent.

\section{The estimates suggest that credit growth boosts the profitability of Greek} banks in the short term but erodes stability over a longer horizon. That is, stability increases with the first lag of credit growth, as with euro area banks, but deteriorates two years after credit increases, although the effect is small (Table 3). Segoviano Basurto, Goodhart, and Hofman (2006) also find that there is a lag between the time a lending boom takes place and the time financial fragility materializes. These results suggest that, while banks in the euro area may be able to contain risks and/or build up sufficient capital as credit growth increases, that is not the case in Greece. As expected, stability shows some persistence: banks that are sound today are more likely to be sound tomorrow. Surprisingly, however, vulnerability rises with cost efficiency and size, although this result is consistent with De Nicoló (2000), who finds that insolvency risk increases in size for banks in industrialized countries. Finally, GDP per capita and real GDP growth increase stability. These results largely hold for the period 1999-2005, although recall that these estimates are inconsistent.

\section{House price inflation has a short-term positive effect on the financial stability} of Greek banks. Credit growth in Greece has largely been driven by household loans, of which 65 percent are mortgages, while real property prices have risen by an average of 5.8 percent since 2001. To analyze whether a combination of lending and property price increases may raise the likelihood of financial fragility, an interaction term between credit growth and house price inflation is included in equation (2). The results suggest that the stability of Greek banks increases as credit growth and house price inflation increase, but no effect is evident for euro-area banks (Table 4). One explanation is that the Greek credit boom does not appear to be related to a housing price bubble.

\section{Asymmetric effects}

18. To test the presence of asymmetric effects of credit growth over the cycle, two types of downturns are considered: real sector downturns and stock market busts.

\footnotetext{
${ }^{40}$ Using the full possible instrument matrix adds little explanatory power but may lead to finite sample bias.
} 
Following Ruiz-Arranz (2003) and Vermeulen (2002), a real downturn occurs if industrial production falls. Table 5 presents data on industrial production for the euro-area countries, with the shaded areas identifying downturn years. For example, Greece experienced industrial production declines in 2001 and 2005. A stock market bust is defined as a decline in the stock market index. According to this measure, Greece experienced an equity market downturn in 1995, and during 2000-2003 (Table 6). Asymmetric effects are captured by modifying equation (2) to allow a different parameter on credit growth during a downturn:

$$
\begin{aligned}
& F_{i, t}=\alpha_{i}+\delta_{t}+\beta_{1} F_{i, t-1}+\left(\beta_{21}+\beta_{22} R_{t}\right) \text { Credit }_{i, t-1}+\left(\beta_{31}+\beta_{32} R_{t}\right) \text { Credit }_{i, t-2}+ \\
& +\left(\beta_{41}+\beta_{42} R_{t}\right) \text { Credit }_{i, t-1} * d_{G R C}+\left(\beta_{51}+\beta_{52} R_{t}\right) \text { Credit }_{i, t-2} * d_{G R C} \\
& +\beta_{6} \text { Macro }_{j t-1}+\beta_{7} \text { Bank }_{i, t-1}+u_{i}+\varepsilon_{i, t}
\end{aligned}
$$

where $R_{t}$ is a dummy variable that indicates a downturn at time $t$ and $\beta_{k 2}$ measures the existence of asymmetric effects.

\section{Credit growth seems to have a larger and more immediate negative effect on} the stability of Greek banks during real downturns. Table 7 (column 2) indicates that Greek banks with higher credit growth are more likely to suffer a deterioration in their financial stability following a downturn, but only in the 1999-2005 period, perhaps owing to the lack of a real downturn before that. These results should be interpreted with caution, particularly, because industrial production might not be a good measure of economic downturns in countries like Greece, where the manufacturing sector is small and where real GDP growth has been consistently strong. Econometric results using a measure of the output gap (not shown) indicate that credit growth has a larger negative impact during downturns, but the effect is not immediate. Surprisingly, credit growth seems to improve the stability of euro-area banks during downturns (Table 7, columns 1 and 2). One possible explanation is that banks anticipate the slowdown and tighten their credit standards. ${ }^{41}$

\section{The outstanding amount of lending seems to be an important determinant of} financial stability of banks in the euro area. As loan growth increases, it may outstrip deposit growth, resulting in an increased reliance on nonretail and potentially more costly and volatile funding sources, such as capital market issues and borrowing in the interbank market. This outcome may increase banks' vulnerability by cutting margins and increasing dependence on cross-border flows with risks of availability and cost. To test the effect of the amount of lending, equation (3) is re-estimated allowing the interaction of credit growth with the ratio of loans to deposits and short-term funding (Table 7, columns 3 and 4). After controlling for lending size, the credit growth of euro-area banks reduces stability

\footnotetext{
${ }^{41}$ There is evidence that banks change their lending standards (from laxity to tightness) systematically during the real business cycle. See, for example, Asea and Blomberg (1997).
} 
during downturns. That is, the higher the level of lending relative to deposits, the more likely credit growth will weaken bank soundness during a downturn. The results for Greek banks are not statistically different from those of banks in other euro area countries.

\section{Credit growth seems to have a larger and more immediate negative effect on} Greek banks' stability during stock market busts as well. Table 8 indicates that the first lag of credit growth has a negative impact on the stability of Greek banks when stock market valuations are falling, contrary to the findings for euro-area banks. However, the second lag of credit growth has a positive effect on the financial stability of Greek banks during stock market downturns (but only for years after 1998).

\section{Threshold effects}

22. The effect of credit growth may become more intense when credit growth exceeds a certain threshold. To test this hypothesis, the banks with the fastest credit expansion, that is, those banks in the upper decile of the credit growth distribution, are isolated:

$$
\begin{aligned}
& F S_{i, t}=\alpha_{i}+\delta_{t}+\beta_{1} F S_{i, t-1}+\left(\beta_{21} D_{0-75}^{C}+\beta_{22} D_{75-90}^{C}+\beta_{23} D_{90-100}^{C}\right)_{C^{\prime}} \text { redit }_{i, t-1}+ \\
& \left(\beta_{31} D_{0-75}^{C}+\beta_{32} D_{75-90}^{C}+\beta_{33} D_{90-100}^{C} \text { Credit }_{i, t-2}+\right. \\
& \left(\beta_{41} D_{0-75}^{C}+\beta_{42} D_{75-90}^{C}+\beta_{43} D_{90-100}^{C} \text { Credit }_{i, t-1} * d_{G R C}+\right. \\
& +\left(\beta_{51} D_{0-75}^{C}+\beta_{52} D_{75-90}^{C}+\beta_{53} D_{90-100}^{C}\right) \text { Credit }_{i, t-2} * d_{G R C}+ \\
& +\beta_{6} \text { Macro }_{j t-1}+\beta_{7} \text { Bank }_{i, t-1}+u_{i}+\varepsilon_{i, t},
\end{aligned}
$$

where $D_{0-75}^{C}, D_{75-90}^{C}$, and $D_{90-100}^{C}$ are dummy variables for observations below the $75^{\text {th }}$ percentile, between the $75^{\text {th }}$ and 90 percentiles, and above the $90^{\text {th }}$ percentile, respectively, of the distribution of credit growth. ${ }^{42}$

\section{The results suggest that credit growth has a more pronounced impact on} vulnerability for banks with higher credit growth (Table 9). Those with credit growth above the $90^{\text {th }}$ decile have a lagged negative effect on the financial stability of Greek and euro area banks. This result, however, is not robust to changes in the estimation period in the case of euro-area banks. In addition, the immediate effect of credit growth above the $75^{\text {th }}$ percentile on financial soundness is positive for Greek and euro-area banks but negative in the longer term for Greek banks. This difference between Greek and euro-area banks could indicate that lending standards are more relaxed in Greece and, therefore, vulnerabilities start to build up in Greek banks at lower rates of credit growth.

\footnotetext{
${ }^{42}$ In our sample, the $75^{\text {th }}-90^{\text {th }}$ range percentile is defined by credit growth rates between 18.9 and 37.2 percent.
} 


\section{E. Key Risks}

24. Financial soundness indicators suggest that the banking system is profitable and well capitalized (Table 10). Solvency remains satisfactory, and profits are robust, driven by rising lending volumes in Greece and southeastern Europe, wide margins, and some cost cutting through the rationalization of branch networks (resulting from mergers), investments in IT, and the implementation of voluntary retirement plans in some banks. Solvency ratios have been supported by the increase in capital of certain credit institutions and the gradual increase of subordinated and hybrid capital in total own funds. Capital adequacy ratios fell slightly in the first half of 2006, however, because risk-weighted assets grew faster than own funds.

\section{However, the strong credit expansion of recent years, which is well above} deposit growth, has increased Greek banks' exposure to liquidity and refinancing risks. Although liquidity is satisfactory-the loan-to-deposit ratio was 97 percent in Greece in 2005, compared with 122 percent in the euro area in 2004-Greek banks are relying increasingly on the interbank money markets, as well as on the issuance of bank bonds and other debt securities for funding (Figure 7). Nevertheless, Greek banks have started to diversify their funding into new products like euro commercial paper, euro medium-term notes, securitization, and hybrid capital with longer maturities.

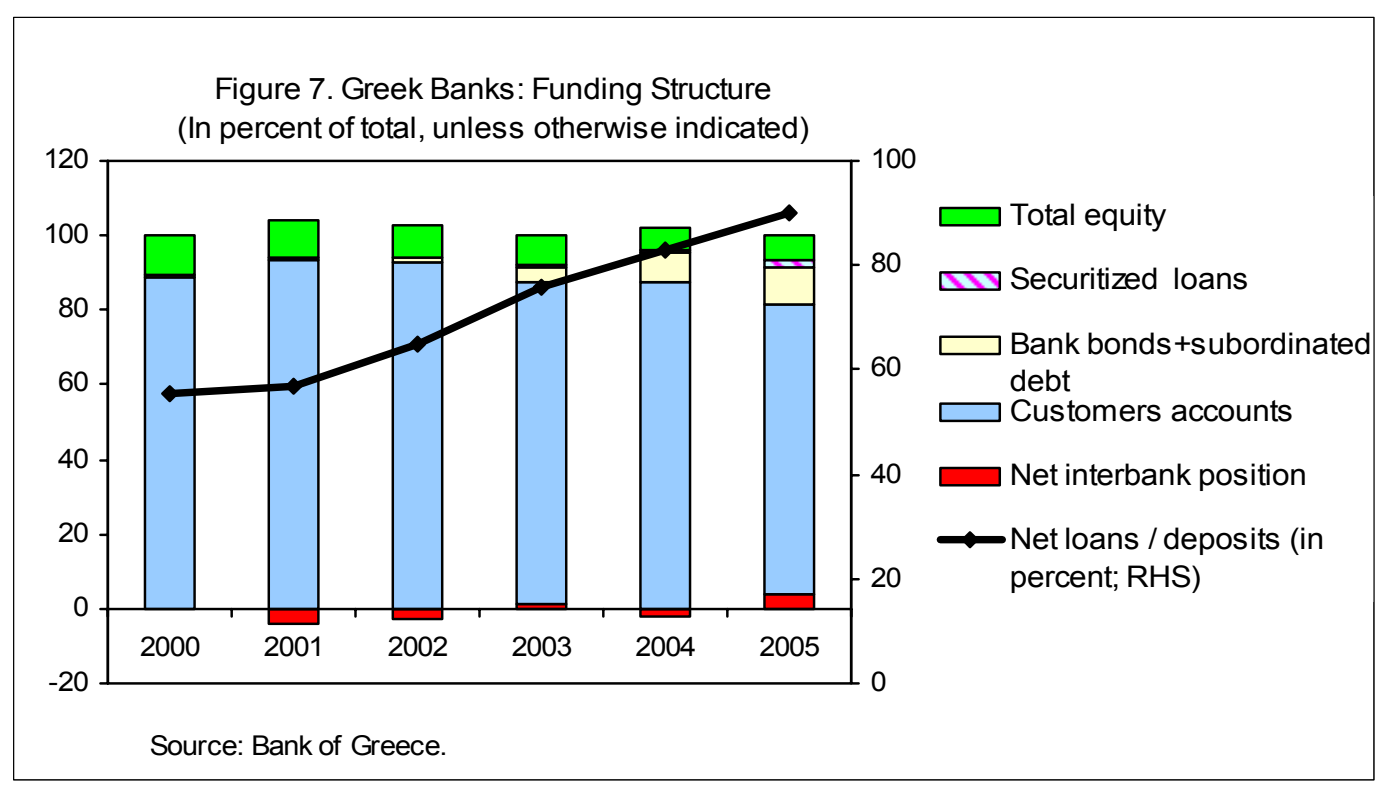




\section{Credit risk exposure is also a concern, as credit growth continues to increase}

at a fast pace. Private sector credit growth strengthened in the first nine months of 2006, driven by the continued

acceleration in residential mortgages that was evident in $2005 .^{43}$ Strong credit expansion to the private sector, notably households, boosts banks' profitability, but is also a potential source of credit risk, especially in the event of an economic downturn or a further rise in euro area interest rates. Since floating-rate loans make up the bulk of loans to households, an interest rate

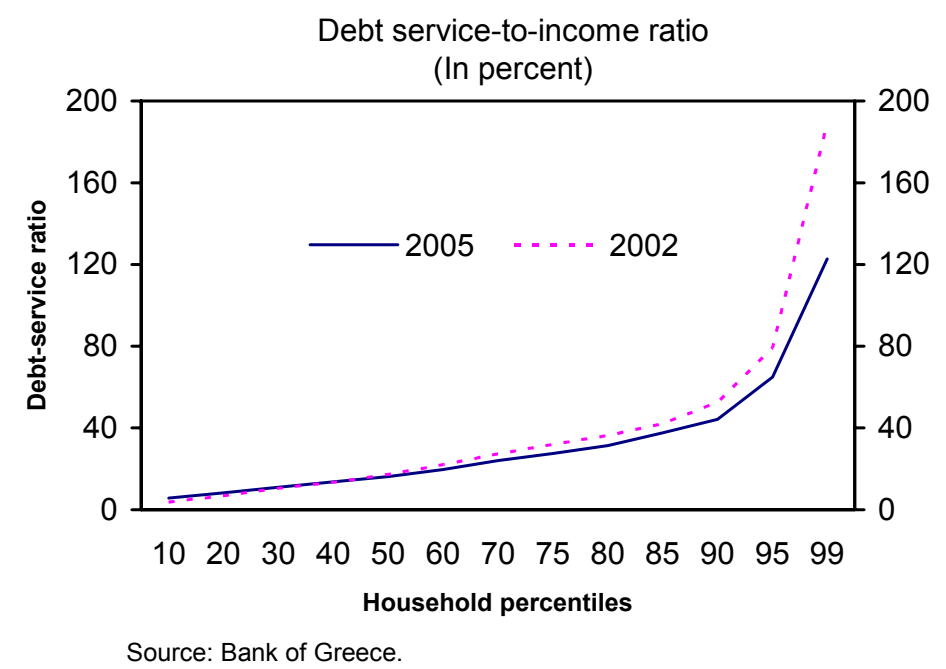
increase would directly push up loan servicing costs for many inexperienced borrowers and, therefore, could worsen banks' credit risk. Also, according to the 2005 household indebtedness survey, 12 percent of households accounting for 30 percent of debt (largely housing loans) had debt- service ratios above 40 percent in 2005 . These households could be under significant financial stress if interest rates rise sharply, magnifying the impact of the shock.

27. Moreover, the NPL ratio has remained stubbornly high. After improving in 2005, the NPL ratio of Greek commercial banks, particularly for consumer loans, deteriorated in the first half of 2006 (while provisioning declined), suggesting that banks continue to lend to poor risks may be to increase their market share. ${ }^{44}$ This is particularly worrisome, considering the large volume of new loans that should be performing and the fact that the cycle has not yet taken a turn for the worse. In addition, although the business loans have grown moderately, the latest migration matrix data for first half of 2006 show a decline in the creditworthiness of the corporate sector, with net downgrades accounting for 6 percent

\footnotetext{
${ }^{43}$ Housing credit growth started to accelerate at end-2005 and has slowed only in recent months. This acceleration is partly due to the introduction of value-added tax (VAT) in newly built residential properties and the readjustment of objective values of the housing stock as of January 1. Consumer credit growth has started to accelerate in the second half of 2006 and remains high.

${ }^{44}$ The decline in NPLs in 2005 was partly attributable to an impressive increase in bad-loan write-offs. Banks took advantage of a decision of the Bank of Greece that allowed them to set off a part of these write-offs against the provisioning shortfall, which, in turn, is deducted from own funds for the calculations of the capital adequacy ratio. Net of this effect, total NPLs (excluding restructured loans) would have risen by 22.7 percent year on year.
} 
of total corporate loans. Large exposures in Greek banks increased from 145 percent in 2005 to 151 percent in the first nine months of 2006. Nonetheless, some of the larger corporates are utility companies with relatively stable revenue sources and subtle government backing.
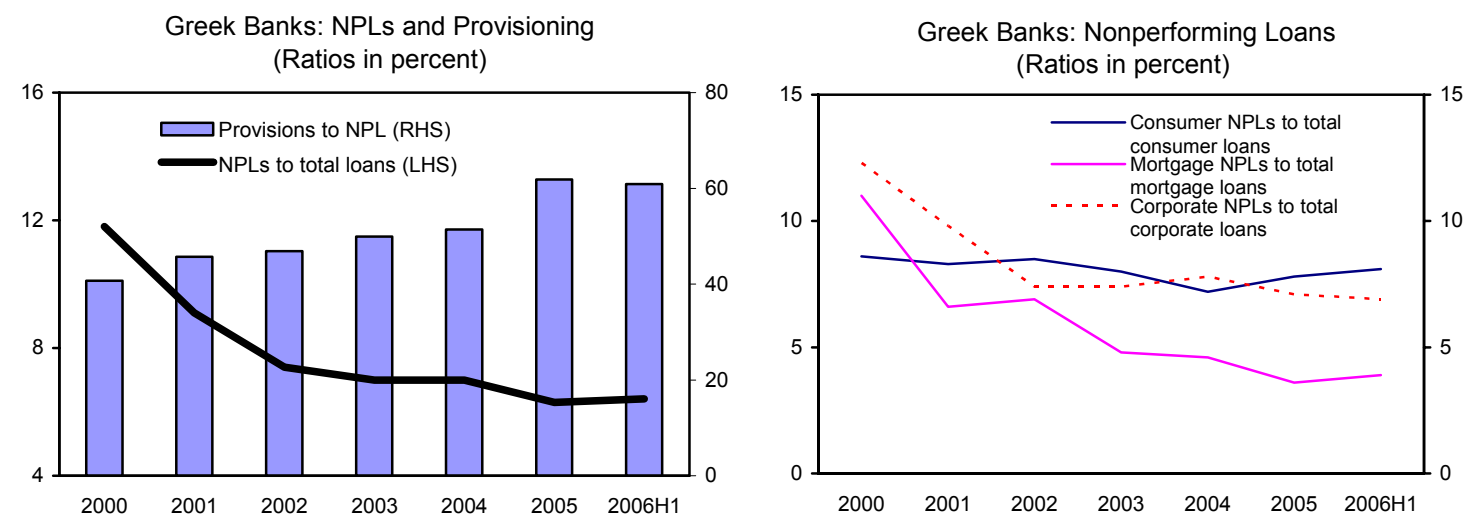

28. The expansion of Greek banks into southeastern Europe through mergers and acquisitions carries benefits but can also involve risks. In 2005, Greek banks accounted for 15.3 percent of southeastern Europe's market share. These acquisitions have expanded the deposit base and could help diversify earnings and improve Greek banks' scale and efficiency. However, such geographic expansion involves funding, operational, and country risks:

- $\quad$ Funding risk. The major banking groups have funded their foreign acquisitions mainly through their capital accumulation and the issuance of subordinated debt and hybrid capital. So far, most of the acquisitions of Greek banks have been gradual (extended over a few years) and the disbursements made in relatively small quantities, not requiring equity issuance. Although securitization has so far been minimal, Eurobank EFG has expressed its intention to securitize part of its small and medium-sized enterprise (SME) loan portfolio (around $€ 2$ billion) and use some of the proceeds to finance acquisitions abroad. Going forward, however, the expansion into new markets may require greater reliance on more volatile wholesale funding.

- Operational risk. This risk arises from errors in trading activities or outright fraud that goes undetected because of a lack of proper internal controls. To mitigate this risk, parent banks in Greece should carefully monitor internal controls and corporate governance of the foreign subsidiaries. According to IMF(2006), the Bank of Greece (BoG) inspectors have found that risk management capabilities in the Greek banks' subsidiaries may be insufficient.

- Country risk. Southeastern Europe is a riskier banking environment, rendering Greek banks more vulnerable to adverse developments in the region.

29. The risks highlighted above are somewhat mitigated by the following factors: 
- $\quad$ Liquidity risk. The BoG introduced two compulsory minimum liquidity ratios in 2005. First, the liquid asset ratio, stipulates that the ratio of banks' liquid assets maturing in up to 30 days to the cumulative balance of bank deposits maturing in up to 12 months, should exceed 20 percent. Second, the mismatch ratio, stipulates that the ratio of the difference between banks' total assets and total liabilities maturing in up to 30 days to the cumulative balance of bank deposits maturing in up to 12 months should be higher than -25 percent. During the first half of 2006, the Greek banking system was well above those limits.

\section{- $\quad$ Credit risk.}

i. Recent stress tests conduced by the BoG indicate that a 30 percent increase in the probability of default would cause losses that exceed the supervisory provisions, but also, given the buffer provided by the high levels of capitalization, the banking system as a whole would remain resilient.

ii. The BoG has intensified its monitoring of credit developments (loan-to-value ratios for mortgages, approval ratios and overrides for consumer loans and credit cards, and the ratio of monthly installments to disposable income).Also, the BoG monitors banks' exposures above $€ 1$ million to groups of companies.

iii. The BoG has increased the risk weights of mortgages with loan-to-value ratios above 75 percent. In addition, the debt-service ratio for new household loans should not exceed 30-40 percent of disposable income. Moreover, the BoG has increased provisioning requirements and write-offs.

\section{- $\quad$ Expansion into southeastern Europe.}

i. BoG closely monitors the expansion of Greek banks into the region through a multilayered supervisory framework. Among other initiatives, the BoG requires Greek banks that are active internationally to develop methodologies for assessing country risk and to form provisions in order to cover the relevant risks, (i.e., liquidity and foreign exchange) that are not being covered as yet under the harmonized European legislative framework.

ii. Recent stress tests, conducted for the loan books and bond portfolios of Greek banks in the region show that, even under a extreme scenario, the impact on the regulatory capital would be limited.

iii. Greece has signed memoranda of understanding with most southeastern European countries that allow the exchange of information, reports, and prudential returns, as well as on-site examinations by BoG supervisors. 
Table 1. Number of Banks in the Sample by Country and Year

\begin{tabular}{|c|c|c|c|c|c|c|c|c|c|c|c|c|c|}
\hline & 1994 & 1995 & 1996 & 1997 & 1998 & 1999 & 2000 & 2001 & 2002 & 2003 & 2004 & 2005 & $\begin{array}{c}\text { Average } \\
\text { Number of } \\
\text { Obeservations } \\
\text { per Bank }\end{array}$ \\
\hline AUT & 7 & 9 & 14 & 15 & 18 & 22 & 24 & 25 & 30 & 33 & 38 & 32 & 5.1 \\
\hline BE & 14 & 18 & 20 & 24 & 24 & 23 & 21 & 19 & 19 & 19 & 20 & 16 & 6.1 \\
\hline DEU & 53 & 76 & 105 & 144 & 147 & 134 & 125 & 121 & 122 & 118 & 110 & 85 & 6.6 \\
\hline FIN & 5 & 6 & 6 & 6 & 5 & 5 & 4 & 4 & 3 & 3 & 3 & 1 & 6.4 \\
\hline FRA & 93 & 98 & 161 & 167 & 162 & 155 & 140 & 144 & 137 & 132 & 115 & 68 & 6.3 \\
\hline GRC & 1 & 1 & 4 & 5 & 8 & 6 & 7 & 9 & 8 & 10 & 11 & $\ldots$ & 5.0 \\
\hline IRE & 3 & 4 & 6 & 9 & 11 & 11 & 13 & 16 & 17 & 17 & 20 & 13 & 5.0 \\
\hline ITA & 50 & 49 & 56 & 69 & 73 & 75 & 78 & 84 & 80 & 83 & 82 & 26 & 6.0 \\
\hline LUX & 49 & 55 & 70 & 92 & 91 & 90 & 79 & 67 & 66 & 71 & 66 & 51 & 6.7 \\
\hline NET & 20 & 21 & 26 & 27 & 24 & 26 & 23 & 23 & 25 & 22 & 23 & 8 & 6.4 \\
\hline POR & 6 & 8 & 17 & 17 & 15 & 16 & 12 & 10 & 10 & 10 & 10 & 2 & 5.3 \\
\hline SPA & 41 & 44 & 45 & 47 & 50 & 53 & 58 & 57 & 53 & 50 & 53 & 1 & 6.4 \\
\hline Total & 342 & 389 & 530 & 622 & 628 & 616 & 584 & 579 & 570 & 568 & 551 & 303 & 6.2 \\
\hline
\end{tabular}

Sources: Bankscope; and staff estimates.

Table 2. Summary Statistics

\begin{tabular}{|c|c|c|c|c|c|c|c|c|}
\hline \multirow[b]{3}{*}{ Variable } & \multicolumn{4}{|c|}{ 1994-2005 } & \multicolumn{4}{|c|}{ 1999-2005 } \\
\hline & \multicolumn{2}{|c|}{ GRC } & \multicolumn{2}{|c|}{ Euro 1/ } & \multicolumn{2}{|c|}{ GRC } & \multicolumn{2}{|c|}{ Euro 1/ } \\
\hline & Mean & Std. Dev. & Mean & Std. Dev. & Mean & Std. Dev. & Mean & Std. Dev \\
\hline Distance to default & 156.9 & 217.2 & 203.6 & 201.2 & 137.6 & 125.8 & 214.8 & 199.9 \\
\hline Credit growth & 17.1 & 26.4 & 3.8 & 30.6 & 23.7 & 25.7 & 6.6 & 31.7 \\
\hline Cost-to-income ratio & 66.5 & 17.1 & 67.2 & 30.6 & 66.0 & 15.1 & 66.6 & 33.1 \\
\hline Bank size & 8.8 & 1.5 & 7.4 & 1.9 & 9.1 & 1.4 & 7.3 & 1.9 \\
\hline GDP per capita & 9.4 & 0.1 & 10.2 & 0.3 & 9.4 & 0.1 & 10.2 & 0.3 \\
\hline Real GDP growth & 3.8 & 1.1 & 2.4 & 2.0 & 4.2 & 0.6 & 2.7 & 2.0 \\
\hline House price inflation & 5.8 & 4.2 & 1.9 & 6.0 & 7.0 & 4.1 & 4.2 & 6.1 \\
\hline
\end{tabular}

1/ Excluding Greece.

Sources: Bankscope; and staff estimates.

CInternational Monetary Fund. Not for Redistribution 


\begin{tabular}{|c|c|c|}
\hline & $(1)$ & $(2)$ \\
\hline \multirow[t]{2}{*}{$\mathrm{FS}_{\mathrm{t}-1}$} & 0.286 & 0.315 \\
\hline & $(8.11)^{* *}$ & $(6.84)^{* *}$ \\
\hline \multirow[t]{2}{*}{ Credit $_{t-1}$} & 0.385 & 0.470 \\
\hline & $(1.99)^{*}$ & (1.73)+ \\
\hline \multirow[t]{2}{*}{ Credit $_{-2}$} & -0.042 & -0.027 \\
\hline & $(1.10)$ & $(0.53)$ \\
\hline \multirow[t]{2}{*}{ Credit $_{\mathrm{t}-1}$ ( Greek banks) } & 2.396 & 2.122 \\
\hline & $(3.41)^{* *}$ & $(2.54)^{*}$ \\
\hline \multirow[t]{2}{*}{ Credit $_{\mathrm{t}-2}($ Greek banks) } & -0.764 & -0.968 \\
\hline & $(1.89)+$ & $(3.05)^{\star *}$ \\
\hline \multirow[t]{2}{*}{ Cost-to-income } & 0.354 & 0.449 \\
\hline & $(3.36)^{* *}$ & $(3.73)^{* *}$ \\
\hline \multirow[t]{2}{*}{ Size } & -45.887 & -39.324 \\
\hline & $(4.18)^{* *}$ & $(2.70)^{* *}$ \\
\hline \multirow[t]{2}{*}{ GDP per capita } & 140.527 & 169.339 \\
\hline & $(9.18)^{\star *}$ & $(7.95)^{\star *}$ \\
\hline \multirow[t]{2}{*}{ Real GDP growth } & 1.895 & -0.957 \\
\hline & $(3.07)^{* *}$ & $(0.64)$ \\
\hline \multirow{2}{*}{ Constant } & 3.882 & -0.317 \\
\hline & $(4.56)^{\star *}$ & $(0.24)$ \\
\hline Observations & 6282 & 3771 \\
\hline Number of banks & 1009 & 848 \\
\hline Sargan test ${ }^{21}$ & $\begin{array}{c}119.35 \\
(0.20)\end{array}$ & $\begin{array}{c}86.96 \\
(0.04)^{*}\end{array}$ \\
\hline Serial correlation ${ }^{3 /}$ & $\begin{array}{c}0.40 \\
(0.69)\end{array}$ & $\begin{array}{l}-0.49 \\
(0.63)\end{array}$ \\
\hline
\end{tabular}

Notes:

Robust $z$ statistics in parentheses.

+ significant at $10 \%$; * significant at $5 \%$; ** significant at $1 \%$.

1/ Dependent variable is $F S_{\mathrm{t}}$ Column (1) reports the estimates for the whole sample, while column (2) reports estimates for the period 1999-2005. All bank-specific and macro variables are lagged by one year to avoid simultaneity problems.

2 / Sargan test is the $\chi^{2}$ statistics of a test of the null hypothesis that the overidentifying restrictions are valid. Statistics are based on two-step estimator. $P$-values are reported in parentheses.

3/ Serial correlation is the Z-statistic from a test of the null hypothesis of no second-order serial correlation in the residuals. $P$-values are reported in parentheses. 
Table 4. Baseline Specification including Real House Price Inflation 1/

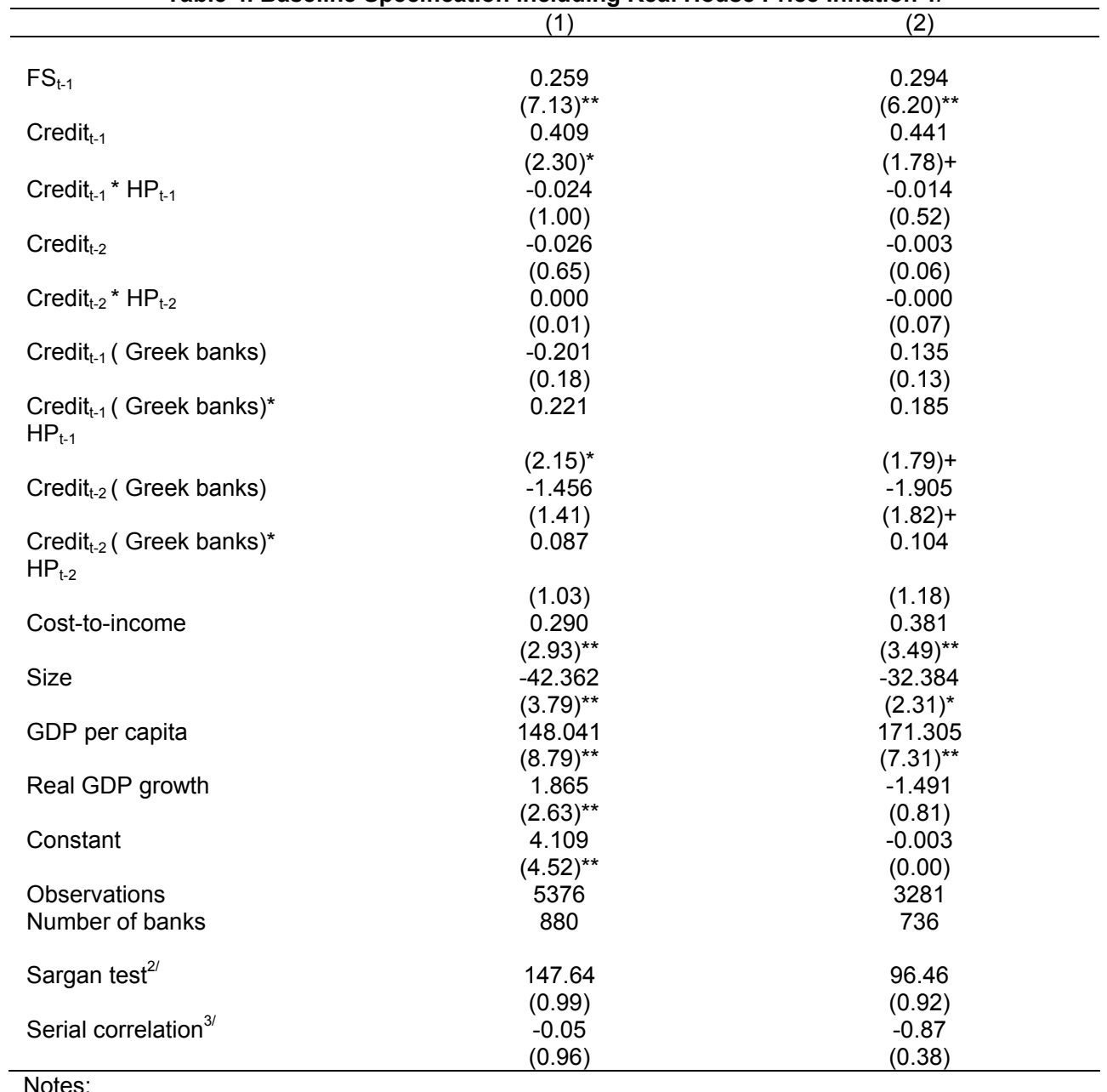

Robust $z$ statistics in parentheses.

+ significant at $10 \% ;{ }^{*}$ significant at $5 \% ;{ }^{*}$ significant at $1 \%$.

1/ Dependent variable is $F S_{t .}$ Column (1) reports the estimates for the whole sample, while column (2) reports estimates for the period 1999-2005. All bank-specific and macro variables are lagged by one year to avoid simultaneity problems. The variable HP refers to real house price inflation.

2/ Sargan test is the $\chi^{2}$ statistics of a test of the null hypothesis that the overidentifying restrictions are valid. Statistics are based on two-step estimator. $P$-values are reported in parentheses.

3/ Serial correlation is the Z-statistic from a test of the null hypothesis of no second-order serial correlation in the residuals. $P$-values are reported in parentheses. 
Table 5. Industrial Production Growth Rates (In percent)

\begin{tabular}{|c|c|c|c|c|c|c|c|c|c|c|c|c|}
\hline & AUT & BEL & DEU & FIN & FRA & GRC & IRE & ITA & LUX & NET & POR & SPA \\
\hline 1994 & 6.0 & 2.9 & 3.6 & 11.2 & 4.6 & 1.0 & 12.0 & 5.8 & 2.2 & 4.9 & -0.3 & 6.2 \\
\hline 1995 & 6.3 & 5.5 & 0.4 & 6.8 & 1.9 & 1.8 & 20.5 & 5.3 & -0.8 & 3.5 & 11.3 & 4.9 \\
\hline 1996 & 0.9 & 0.5 & -0.5 & 3.9 & -2.0 & 0.8 & 8.1 & -1.4 & -2.2 & 2.3 & 4.8 & -1.0 \\
\hline 1997 & 6.8 & 4.3 & 2.4 & 9.0 & 1.9 & 1.9 & 17.5 & 3.0 & 4.7 & 0.3 & 1.6 & 5.9 \\
\hline 1998 & 9.6 & 2.8 & 3.2 & 8.8 & 3.4 & 8.9 & 19.8 & 1.7 & 5.8 & 2.4 & 4.5 & 6.4 \\
\hline 1999 & 5.1 & 1.4 & 1.1 & 5.0 & 2.5 & 2.0 & 14.8 & 1.6 & 2.2 & 1.2 & 0.2 & 4.2 \\
\hline 2000 & 9.6 & 5.1 & 4.8 & 11.6 & 4.8 & 7.2 & 15.4 & 3.6 & 4.8 & 3.3 & -0.2 & 5.0 \\
\hline 2001 & 2.0 & -1.4 & -0.4 & 0.4 & 1.2 & -1.9 & 10.0 & -0.2 & 3.4 & 0.6 & 3.1 & 0.9 \\
\hline 2002 & 0.7 & 0.7 & -1.3 & 1.9 & -1.6 & 0.8 & 7.2 & -0.7 & 2.1 & 0.9 & -0.4 & 1.7 \\
\hline 2003 & 4.0 & 0.0 & 0.1 & 1.8 & 0.2 & 0.3 & 4.7 & -0.5 & 3.0 & -1.4 & 0.1 & 2.2 \\
\hline 2004 & 5.9 & 2.3 & 2.5 & 4.6 & 2.7 & 1.1 & 0.3 & 1.2 & 2.2 & 2.5 & -2.7 & 1.8 \\
\hline 2005 & 4.4 & -1.0 & 2.8 & -1.1 & 0.9 & -0.7 & 3.0 & -0.9 & 0.9 & -1.2 & 0.3 & 1.0 \\
\hline
\end{tabular}

Sources: Eurostat; and National Statistical Offices.

Table 6. European Stock Market Indices

\begin{tabular}{|c|c|c|c|c|c|c|c|c|c|c|c|c|}
\hline $\begin{array}{c}\text { Country } \\
\text { Stock market Index }\end{array}$ & $\begin{array}{l}\text { AUT } \\
\text { ATX }\end{array}$ & $\begin{array}{c}\text { BEL } \\
\text { BEL20 }\end{array}$ & $\begin{array}{l}\text { DEU } \\
\text { DAX }\end{array}$ & $\begin{array}{l}\text { FIN } \\
\text { OMX }\end{array}$ & $\begin{array}{l}\text { FRA } \\
\text { CAC }\end{array}$ & $\begin{array}{l}\text { GRC } \\
\text { ASE }\end{array}$ & $\begin{array}{l}\text { IRE } \\
\text { ISEQ }\end{array}$ & $\begin{array}{l}\text { ITA } \\
\text { MIB30 }\end{array}$ & $\begin{array}{l}\text { LUX } \\
\text { LUXXX }\end{array}$ & $\begin{array}{l}\text { NET } \\
\text { AEX }\end{array}$ & $\begin{array}{l}\text { POR } \\
\text { BVLX }\end{array}$ & $\begin{array}{l}\text { SPA } \\
\text { MADX }\end{array}$ \\
\hline 1994 & 1096.7 & 1452.5 & 2120.9 & 283.8 & 2056.7 & 922.1 & 1856.0 & 15761.7 & & 186.5 & 920.7 & 315.2 \\
\hline 1995 & 988.9 & 1425.2 & 2138.0 & 320.3 & 1871.7 & 889.2 & 2011.6 & 14605.4 & & 199.1 & 889.7 & 295.8 \\
\hline 1996 & 1073.5 & 1741.2 & 2569.0 & 388.9 & 2079.4 & 936.1 & 2507.5 & 14862.4 & & 252.3 & 1028.1 & 361.1 \\
\hline 1997 & 1291.3 & 2293.8 & 3720.0 & 576.9 & 2757.9 & 1480.5 & 3394.3 & 20410.6 & & 377.3 & 1615.6 & 552.0 \\
\hline 1998 & 1335.5 & 3112.9 & 5021.1 & 693.8 & 3702.1 & 2192.1 & 4788.1 & 32111.0 & & 496.3 & 2557.3 & 810.3 \\
\hline 1999 & 1176.3 & 3215.5 & 5347.1 & 836.7 & 4552.3 & 4413.5 & 5011.2 & 35291.0 & 1080.6 & 564.1 & 2339.2 & 894.9 \\
\hline 2000 & 1128.3 & 2966.5 & 7120.4 & 1294.3 & 6269.5 & 4277.2 & 5346.2 & 46240.1 & 1599.5 & 664.9 & 2835.0 & 1007.0 \\
\hline 2001 & 1157.2 & 2806.6 & 5614.6 & 870.5 & 5019.3 & 2825.3 & 5725.9 & 36467.6 & 1243.3 & 544.9 & 2182.2 & 853.7 \\
\hline 2002 & 1183.9 & 2409.6 & 4176.7 & 631.2 & 3789.1 & 2154.0 & 4674.8 & 27846.9 & 961.0 & 419.5 & 1781.4 & 726.7 \\
\hline 2003 & 1305.1 & 1975.4 & 3198.3 & 546.5 & 3119.1 & 1911.2 & 4348.5 & 24926.5 & 836.4 & 304.6 & 1659.3 & 705.9 \\
\hline 2004 & 1979.6 & 2555.6 & 3983.3 & 696.1 & 3685.3 & 2437.8 & 5457.2 & 28215.4 & 1091.3 & 339.2 & 2115.0 & 860.3 \\
\hline 2005 & 2996.3 & 3193.2 & 4678.1 & 829.5 & 4269.5 & 3154.4 & 6535.8 & 32914.8 & 1414.0 & 384.9 & 2354.1 & 1060.6 \\
\hline
\end{tabular}

Source: Bloomberg. 
Table 7. Asymmetric Effects over Real Sector Downturns 1/




Table 8. Asymmetric Effects over Equity Price Cycles $1 /$

\begin{tabular}{|c|c|c|}
\hline & $(1)$ & $(2)$ \\
\hline \multirow[t]{2}{*}{$\mathrm{FS}_{\mathrm{t}-1}$} & 0.279 & 0.341 \\
\hline & $(7.63)^{\star *}$ & $(7.24)^{\star *}$ \\
\hline \multirow[t]{2}{*}{ Credit $_{t-1}$} & 0.158 & -0.108 \\
\hline & $(0.72)$ & $(0.40)$ \\
\hline \multirow[t]{2}{*}{ Credit $_{t-1}{ }^{*} R_{t}$} & 0.564 & 1.248 \\
\hline & $(1.68)+$ & $(3.05)^{* *}$ \\
\hline \multirow[t]{2}{*}{ Credit $_{\mathrm{t}-2}$} & 0.010 & 0.058 \\
\hline & $(0.21)$ & $(0.70)$ \\
\hline \multirow[t]{2}{*}{ Credit $_{t-2}{ }^{*} R_{t}$} & -0.087 & -0.142 \\
\hline & $(0.94)$ & (1.19) \\
\hline \multirow[t]{2}{*}{ Credit $_{\mathrm{t}-1}$ ( Greek banks) } & 3.349 & 3.987 \\
\hline & $(2.68)^{* *}$ & $(2.47)^{*}$ \\
\hline \multirow{2}{*}{ Credit $_{\mathrm{t}-1}\left(\right.$ Greek banks$^{*} \mathrm{R}_{\mathrm{t}}$} & -2.440 & -4.680 \\
\hline & $(1.65)+$ & $(2.63)^{\star *}$ \\
\hline \multirow[t]{2}{*}{ Credit $_{\mathrm{t}-2}$ ( Greek banks) } & -2.432 & -4.744 \\
\hline & $(1.25)$ & $(2.37)^{\star}$ \\
\hline \multirow[t]{2}{*}{ Credit $_{t-2}\left(\right.$ Greek banks) ${ }^{*} R_{t}$} & 2.163 & 4.315 \\
\hline & $(1.16)$ & $(2.24)^{*}$ \\
\hline \multirow[t]{2}{*}{ Cost-to-income } & 0.306 & 0.410 \\
\hline & $(3.03)^{\star *}$ & $(3.50)^{* *}$ \\
\hline \multirow[t]{2}{*}{ Size } & -42.759 & -37.043 \\
\hline & $(3.61)^{\star *}$ & $(2.46)^{*}$ \\
\hline \multirow[t]{2}{*}{ Real GDP per capita } & 152.682 & 207.893 \\
\hline & $(7.81)^{* *}$ & $(7.28)^{\star *}$ \\
\hline \multirow[t]{2}{*}{ Real GDP growth } & 1.835 & -1.756 \\
\hline & $(2.69)^{\star \star}$ & $(1.07)$ \\
\hline \multirow[t]{2}{*}{ Constant } & 3.614 & -1.094 \\
\hline & $(3.89)^{* *}$ & $(0.77)$ \\
\hline Observations & 5750 & 3602 \\
\hline Number of banks & 966 & 820 \\
\hline \multirow[t]{2}{*}{ Sargan test $\mathrm{t}^{2 /}$} & 144.02 & 90.26 \\
\hline & $(1.00)$ & $(0.97)$ \\
\hline Serial correlation ${ }^{3 /}$ & $\begin{array}{c}0.41 \\
(0.68)\end{array}$ & $\begin{array}{l}-0.45 \\
(0.66)\end{array}$ \\
\hline
\end{tabular}

Notes:

Robust $z$ statistics in parentheses. + significant at $10 \% ;{ }^{*}$ significant at $5 \% ;{ }^{* *}$ significant at $1 \%$.

1/ Dependent variable is $F S_{t .}$ Columns (1) reports the estimates for the whole sample, while column (2) reports estimates for the period 1999-2005. All bank-specific and macro variables are lagged by one year to avoid simultaneity problems. $R_{t}$ is a dummy variable that indicates if there was a stock market downturn at time $t$.

$2 /$ Sargan test is the $\chi^{2}$ statistics of a test of the null hypothesis that the overidentifying restrictions are valid. Statistics are based on two-step estimator. $P$ - values are reported in parentheses.

3/ Serial correlation is the Z-statistic from a test of the null hypothesis of no second-order serial correlation in the residuals. $P$-values are reported in parentheses. 
Table 9. Threshold Effects 1/

\begin{tabular}{|c|c|c|}
\hline & (1) & $(2)$ \\
\hline $\mathrm{FS}_{\mathrm{t}-1}$ & $\begin{array}{c}0.264 \\
(7.95)^{\star *}\end{array}$ & $\begin{array}{c}0.275 \\
(6.44)^{* *}\end{array}$ \\
\hline Credit $_{\mathrm{t}-1}{ }^{*} \mathrm{D}_{1}$ & $\begin{array}{l}0.080 \\
(0.31)\end{array}$ & $\begin{array}{l}-0.294 \\
(0.63)\end{array}$ \\
\hline Credit $_{t-1}{ }^{*} D_{2}$ & $\begin{array}{l}0.603 \\
(1.51)\end{array}$ & $\begin{array}{l}0.678 \\
(1.48)\end{array}$ \\
\hline Credit $_{\mathrm{t}-1}{ }^{*} \mathrm{D}_{3}$ & $\begin{array}{l}0.198 \\
(0.73)\end{array}$ & $\begin{array}{l}0.395 \\
(1.18)\end{array}$ \\
\hline Credit $_{\mathrm{t}-2}{ }^{*} \mathrm{D}_{1}$ & $\begin{array}{l}0.027 \\
(0.34)\end{array}$ & $\begin{array}{l}0.030 \\
(0.31)\end{array}$ \\
\hline Credit $_{\mathrm{t}-2}{ }^{*} \mathrm{D}_{2}$ & $\begin{array}{c}0.396 \\
(2.33)^{\star}\end{array}$ & $\begin{array}{c}0.440 \\
(1.85)+\end{array}$ \\
\hline Credit $_{\mathrm{t}-2}{ }^{*} \mathrm{D}_{3}$ & $\begin{array}{l}-0.090 \\
(1.92)+\end{array}$ & $\begin{array}{l}-0.088 \\
(1.19)\end{array}$ \\
\hline Credit $_{\mathrm{t}-1}\left(\right.$ Greek banks) ${ }^{*} \mathrm{D}_{1}$ & $\begin{array}{c}2.554 \\
(6.12)^{\star *}\end{array}$ & $\begin{array}{c}2.349 \\
(3.43)^{\star *}\end{array}$ \\
\hline Credit $_{\mathrm{t}-1}\left(\right.$ Greek banks) ${ }^{*} \mathrm{D}_{2}$ & $\begin{array}{l}-0.137 \\
(0.21)\end{array}$ & $\begin{array}{l}-0.553 \\
(0.70)\end{array}$ \\
\hline Credit $_{\mathrm{t}-1}\left(\right.$ Greek banks) ${ }^{*} \mathrm{D}_{3}$ & $\begin{array}{c}1.270 \\
(3.02)^{\star *}\end{array}$ & $\begin{array}{l}0.862 \\
(1.61)\end{array}$ \\
\hline Credit $_{t-2}\left(\right.$ Greek banks) ${ }^{*} D_{1}$ & $\begin{array}{r}-1.190 \\
(0.77)\end{array}$ & $\begin{array}{r}-1.429 \\
(1.09)\end{array}$ \\
\hline Credit $_{t-2}\left(\right.$ Greek banks) ${ }^{*} D_{2}$ & $\begin{array}{l}-1.760 \\
(1.69)+\end{array}$ & $\begin{array}{l}-2.246 \\
(2.39)^{*}\end{array}$ \\
\hline Credit $_{t-2}\left(\right.$ Greek banks) ${ }^{*} D_{3}$ & $\begin{array}{l}-0.877 \\
(2.34)^{*}\end{array}$ & $\begin{array}{l}-1.106 \\
(3.57)^{\star \star}\end{array}$ \\
\hline Cost-to-income & $\begin{array}{c}0.308 \\
(3.13)^{\star *}\end{array}$ & $\begin{array}{c}0.391 \\
(3.58)^{\star *}\end{array}$ \\
\hline Size & $\begin{array}{l}-39.785 \\
(4.16)^{\star *}\end{array}$ & $\begin{array}{l}-29.543 \\
(2.32)^{*}\end{array}$ \\
\hline GDP per capita & $\begin{array}{l}120.147 \\
(7.44)^{\star *}\end{array}$ & $\begin{array}{l}143.742 \\
(6.34)^{\star *}\end{array}$ \\
\hline Real GDP growth & $\begin{array}{l}2.287 \\
(3.73)^{\star *}\end{array}$ & $\begin{array}{l}0.071 \\
(0.05)\end{array}$ \\
\hline Constant & $\begin{array}{l}3.501 \\
(4.16)^{\star *}\end{array}$ & $\begin{array}{r}-0.752 \\
(0.60)\end{array}$ \\
\hline $\begin{array}{l}\text { Observations } \\
\text { Number of banks }\end{array}$ & $\begin{array}{l}6282 \\
1009\end{array}$ & $\begin{array}{c}3771 \\
848\end{array}$ \\
\hline Sargan test $\mathrm{t}^{2 /}$ & $\begin{array}{c}184.11 \\
(1.00)\end{array}$ & $\begin{array}{c}126.31 \\
(0.99)\end{array}$ \\
\hline Serial correlation ${ }^{3 /}$ & $\begin{array}{l}-0.15 \\
(0.88) \\
\end{array}$ & $\begin{array}{l}-1.04 \\
(0.30) \\
\end{array}$ \\
\hline
\end{tabular}

Notes:

Robust $z$ statistics in parentheses. + significant at $10 \%$; * significant at $5 \%$; ${ }^{* *}$ significant at $1 \%$.

1/ Dependent variable is $F S_{t}$. Columns (1) reports the estimates for the whole sample, while column (2) reports estimates for the period 1999-2005. All bank-specific and macro variables are lagged by one year to avoid simultaneity problems. $D_{1}, D_{2}, D_{3}$ are dummy variables for observations below the $75^{\text {th }}$ percentile, between the $75^{\text {th }}$ and 90 percentiles, and above the $90^{\text {th }}$ percentile, respectively, of the distribution of credit growth.

2/ Sargan test is the $\chi^{2}$ statistics of a test of the null hypothesis that the overidentifying restrictions are valid. Statistics are based on two-step estimator. $P$-values are reported in parentheses.

3 / Serial correlation is the Z-statistic from a test of the null hypothesis of no second-order serial correlation in the residuals. $P$-values are reported in parentheses. 
Table 10. Core Set of Financial Soundness Indicators for Deposit-Taking Institutions 1/

(1998-June 2006, unless otherwise indicated)

\begin{tabular}{|c|c|c|c|c|c|c|c|c|c|}
\hline & 1998 & 1999 & 2000 & 2001 & 2002 & 2003 & 2004 & 2005 & $\begin{array}{c}2006 \\
2 /\end{array}$ \\
\hline Regulatory capital to risk-weighted assets $3 / 4$ / & 10.2 & 16.2 & 13.6 & 12.4 & 10.5 & 12.0 & 12.8 & 13.2 & 12.3 \\
\hline Regulatory Tier I capital to risk-weighted assets $3 / 4$ / & 9.7 & 15.3 & 13.5 & 10.9 & 8.8 & 9.8 & 10.0 & 10.9 & 10.3 \\
\hline Nonperforming loans net of provisions to capital $3 / 5$ / & 29.3 & 24.1 & 23.2 & 17.4 & 18.7 & 16.1 & 16.3 & 18.0 & 19.1 \\
\hline Nonperforming loans to total gross loans $3 / 6$ / & 8.7 & 11.2 & 7.2 & 5.6 & 5.5 & 5.1 & 5.4 & 5.5 & 5.5 \\
\hline \multicolumn{10}{|l|}{$\begin{array}{l}\text { Sectoral distribution of loans to total loans } 7 / \text { (enterprises and households, } \\
\text { domestic and other euro area residents) }\end{array}$} \\
\hline Insurance corporations and pension funds $7 /$ & 0.0 & 0.1 & 0.1 & 0.1 & 0.1 & 0.1 & 0.1 & 0.1 & 0.1 \\
\hline Other financial intermediaries $7 /$ & 0.7 & 0.4 & 1.1 & 2.2 & 3.2 & 2.6 & 2.3 & 1.6 & 1.5 \\
\hline Nonfinancial corporations $7 /$ & 75.0 & 72.2 & 70.5 & 65.7 & 60.4 & 57.7 & 54.4 & 50.4 & 49.5 \\
\hline Consumer credit $7 /$ & 7.3 & 8.4 & 9.3 & 10.6 & 11.3 & 12.3 & 14.3 & 15.2 & 15.7 \\
\hline Lending for house purchase $7 /$ & 17.0 & 18.8 & 18.8 & 21.0 & 24.3 & 26.1 & 27.6 & 31.4 & 32.0 \\
\hline Other lending to households and non-profit institutions serving households $7 /$ & 0.1 & 0.2 & 0.3 & 0.4 & 0.6 & 1.2 & 1.2 & 1.2 & 1.2 \\
\hline Return on assets (after taxes; on a nonconsolidated basis) 8/ & 0.7 & 2.4 & 1.4 & 1.0 & 0.5 & 0.6 & 0.3 & 0.9 & 1.2 \\
\hline Return on equity (after taxes; on a nonconsolidated basis) $8 /$ & 13.7 & 28.6 & 15.4 & 12.4 & 6.8 & 8.9 & 5.6 & 16.2 & 21.7 \\
\hline Interest margin to gross income $8 /$ & 55.1 & 44.5 & 54.5 & 62.8 & 72.5 & 73.9 & 76.3 & 75.3 & 71.1 \\
\hline Noninterest expenses to gross income $8 /$ & 62 & 48 & 53 & 59 & 69 & 63 & 62 & 55 & 48 \\
\hline Liquid assets to total assets $7 /$ & 55.2 & 50.3 & 46.4 & 41.1 & 39.5 & 37.0 & 33.4 & 34.0 & 34.2 \\
\hline Liquid assets to short-term liabilities $7 /$ & 62.6 & 64.6 & 60.7 & 53.0 & 48.7 & 46.5 & 43.2 & 47.0 & 46.8 \\
\hline Net open position in foreign exchange to capital $4 /$ & $\ldots$ & $\ldots$ & $\ldots$ & 3.5 & 7.2 & 5.8 & 3.5 & 2.9 & 0.6 \\
\hline
\end{tabular}

Source: Bank of Greece.

$1 /$ These may be grouped in different peer groups based on control, bsuiness lines, or group structure.

2/ June 2006 figures refer to Greek quoted banks unless otherwise indicated.

3/ June 2006 figures refer to all banks

4/ Data on a consolidated basis.

5/ This figure does not include ATEbank and rescheduled loans. If rescheduled loans were included, then the relevant ratios would become 18.7 for 2005 and 20 for June 2006.

$6 /$ This figure does not include ATEbank and rescheduled loans. If rescheduled loans were included, then the relevant ratios would become 5.6 for 2005 and

5.6 for June 2006.

7/ 2006 figures refer to July 2006 and to all banks on a nonconsolidated basis (i.e., commercial, cooperative, and foreign branches).

$8 /$ On a nonconsolidated basis. From 2004 on, in accordance with IFRS. 


\section{Annex I. Data Sources and Definitions}

The data set used in this paper was created in several steps:

1. Compile information for all banks in the euro area included in the Bankscope database published by the Bureau van Dijk.

2. Bankscope includes both consolidated and unconsolidated balance sheet data. To make sure that observations are not duplicated for the same bank, the following procedure was applied to include information from only one of the balance sheets. First, using the "consolidation code" variable in Bankscope we choose institutions, which will provide one balance sheet for each institution at the highest level of consolidation available. In a second step, we add those banks not included in the first step for which data are available.

3. Exclude outliers and unrealistic observations for the variables used to estimate the base specification. In particular, exclude individual observations where:

- $\quad$ Equity is negative

- $\quad F S_{i, t}<1^{\text {st }}$ percentile or $F S_{i, t}>99^{\text {th }}$ percentile

- $\quad$ Credit $_{i, t-1}<1^{\text {st }}$ percentile or Credit $_{i, t-1}>99^{\text {th }}$ percentile

- $\quad$ Credit $_{i, t-2}<1^{\text {st }}$ percentile or Credit $_{i, t-2}>99^{\text {th }}$ percentile.

\section{Variable definitions}

FS: Financial stability. Return on average assets plus equity as a percent of assets divided by the standard deviation of return on average assets.

Credit: Bank credit growth. Annual percentage change in total loans in real terms (credit deflated by the GDP deflator).

Cost-to-income: Cost-to-income ratio. Total operating expenses divided by total operating income.

Size: Bank size. Logarithm of total real assets in U.S. dollars.

$L D$ : Loan-to-deposit-and-short-term-funding ratio.

Real GDP per capita. Real GDP per capita, in U.S. dollars.

Real GDP growth. Annual growth rate of real GDP.

HP: House price inflation. Annual growth rates of the real house price index. 


\section{References}

Arellano, M., and S., Bond, , 1991, "Some Tests of Specification for Panel Data: Monte Carlo Evidence and an application to Employment Equations," Review of Economic Studies, Vol. 58 (April), pp. 277-97.

Asea, P., and S. B. Blomberg, 1997, “Lending Cycles,” NBER Working Paper No. 5951 (Cambridge, Massachusetts: National Bureau of Economic Research).

Brozá-Brzezina, M, 2005, "Lending Booms in the New EU Member States: Will Euro Adoption Matter?,” ECB Working Paper No. 543 (Frankfurt: European Central Bank).

Cottarelli, C., G. Dell'Ariccia, and I. Vladkova-Hollar, 2005, "Early Birds, Late Risers, and Sleeping Beauties: Bank Credit Growth to the Private Sector in Central and Easter Europe and in the Balkans," Journal of Banking and Finance, Vol..29 (January), pp. 83-104.

Demirgüc-Kunt, A., and E. Detragiache, 1998, "The Determinants of Banking Crises: Evidence from Developing and Developed Countries," IMF Staff Papers, Vol. 45 (March), pp. 81-109.

De Nicoló, G., 2000, "Size, Charter Value and Risk in Banking: An International Perspective," Federal Reserve International Finance Discussion Paper No. 689 (Washington: Federal Reserve Bank).

— and others, 2005, "European Financial Integration, Stability and Supervision," in Euro Area Policies: Selected Issues, IMF Country Report No. 05/266 (August), by A. Annett and others (Washington: International Monetary Fund), pp. 113-46.

Goldfajn, I., and R. Valdés, 1997, "Capital Flows and the Twin Crises: The Role of Liquidity,” IMF Working Paper 97/87 (Washington: International Monetary Fund).

Gourinchas, P., R. Valdés, and O. Landerretche, 2000, “Lending Booms: Some Stylized Facts" (unpublished; Princeton, New Jersey: Princeton University).

Honohan, P, 1999, "Consequences for Greece and Portugal of the Opening-up of the European Banking Market" (unpublished; Washington: The World Bank).

International Monetary Fund, 2006, Greece: Financial System Stability Assessment, IMF Country Report No. 06/6 (Washington: International Monetary Fund). 
Kaminsky, G., and C. Reinhart, 1999, "The Twin Crises: The Causes of Banking and Balance of Payments Problems," American Economic Review, Vol. 89 (June), pp. 473-500.

Maechler, A., S. Mitra, and D. Worrell, 2006, "Exploring Financial Risks and Vulnerabilities in New and Potential EU Member States" (unpublished; Washington: International Monetary Fund).

Ruiz-Arranz, M., 2004, "Corporate Balance Sheets and Investment: Empirical Estimates for Portugal and Other EU Countries," Portugal—Selected Issues, IMF Country Report No. 04/81 (Washington: International Monetary Fund).

Segoviano Basurto, M., C. Goodhart, and B. Hofman, 2006, "Default, Credit Growth, and Asset Prices," IMF Working Paper 06/223 (Washington: International Monetary Fund).

Tamirisa, N. and D. Igan, 2006, "Credit Growth and Bank Soundness in New Member States" (unpublished; Washington: International Monetary Fund).

Vermeulen, P., 2002, "Business Fixed Investment: Evidence of a Financial Accelerator in Europe," Oxford Bulletin of Economics and Statistics, 64, 3, pp. 213-231. 